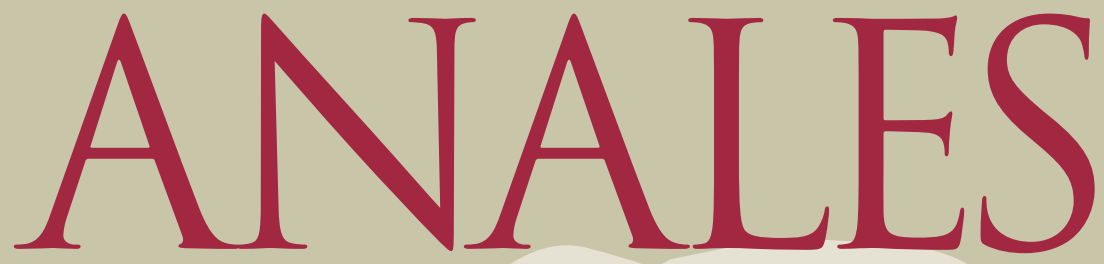

de la Facultad de Derecho

Universidad de La Laguna $37 \quad 2020$ 
Anales de la Facultad de DERECHO 


\section{Anales de la Facultad de DERECHO}

Universidad de La Laguna

DIRECTORA

María Victoria Sansón Rodríguez (ULL)

SUBDIRECTOR

Francisco Lorenzo Hernández González (ULL)

SECRETARIO DE LA REVISTA

Juan Antonio García García (ULL)

CONSEJO DE REDACCIÓN

Marcel Bonnet Escuela (ULL), Etelvina de las Casas León (ULL),

Francisco F. Clavijo Hernández (ULL), Ulises Hernández Plasencia (ULL),

Tomás López-Fragoso Álvarez (ULL), Ruth Martinón Quintero (ULL),

Margarita I. Ramos Quintana (ULL), María Elena Sánchez Jordán (ULL).

\section{CONSEJO ASESOR}

Andrea Bonomi (Université de Lausanne, Suiza), Martín Diego Farrell (Universidad de Buenos Aires, Argentina), Antonio Fernández de Buján (Universidad Autónoma de Madrid), Cesare Maioli (Università di Bologna, Italia), María Elvira Méndez Pineda

(University of Iceland, Islandia), Manuel Carlos Palomeque López (Universidad de Salamanca), María Ángeles Parra Lucán (Universidad de Zaragoza), Johann-Christian Pielow (Ruhr-Universität Bochum, Alemania), Carlos M. ${ }^{a}$ Romeo Casabona (Universidad del País Vasco), María del Carmen Sevilla González (Universidad de La Laguna), Esteban Sola Reche (Universidad de La Laguna), Rolando Tamayo Salmarán (Universidad Nacional

Autónoma de México), Francisco José Villar Rojas (Universidad de La Laguna), Stefan Vogenauer (University of Oxford, Reino Unido).

\section{EDITA}

Servicio de Publicaciones de la Universidad de La Laguna Campus Central. 38200 La Laguna. Santa Cruz de Tenerife Tel.: 34922319198

\section{DISEÑO EDITORIAL}

Jaime H. Vera

Javier Torres/Luis C. Espinosa

\section{MAQUETACIÓN Y PREIMPRESIÓN}

Servicio de Publicaciones

DOI: https://doi.org/10.25145/j.anfade. 2020.37

ISSN: 0075-773X (edición impresa) / ISSN: e-2530-8319 (edición digital)

Depósito Legal: TF 734/81

Prohibida la reproducción total o parcial de esta obra sin permiso del editor. 


\section{Anales de la Facultad de DERECHO 37}


ANALES de la Facultad de Derecho de la Universidad de La Laguna. -La Laguna: Universidad, Servicio de Publicaciones, 1991-

Anual

Es continuación de: Anales de la Universidad de La Laguna. Facultad de Derecho.

ISSN: 0075-773X (edición papel); e-2530-8319 (edición digital)

1. Derecho-Publicaciones periódicas I. Universidad de La Laguna. Facultad de Derecho. 34(05)

La correspondencia relativa a la revista debe dirigirse a:

Anales de la Facultad de Derecho

Servicio de Publicaciones

Universidad de La Laguna

Campus Central

38200 La Laguna (Tenerife, España) 


\title{
SUMARIO / CONTENTS
}

\author{
NÚMERO MONOGRÁFICO SOBRE LOS DERECHOS ECONÓMICOS, \\ SOCIALES, CULTURALES Y MEDIOAMBIENTALES \\ EN EL ÁMBITO LATINOAMERICANO
}

Coordinado por la profesora Ruth Martinón Quintero

INTRODUCCIÓN / INTRODUCTION

Algunas aportaciones del ámbito latinoamericano al Derecho internacional de los derechos humanos, especialmente los DESCA / Some contributions from the Latin American region to international human rights law, especially ESCR

Ruth Martinón Quintero.

\section{Artículos / Articles}

Protección a la vivienda en las sentencias de la Corte Interamericana de Derechos Humanos: escenarios y cumplimiento / Protection of housing in the sentences of the Inter-American Court of Human Rights: scenarios and compliance

Magda Yadira Robles Garza.

Los derechos culturales de los pueblos indígenas en la jurisprudencia de la Corte Interamericana de Derechos Humanos / Cultural rights in the jurisprudence of the Inter-American Court of Human Rights

Jaime Gajardo Falcón.

El derecho al medio ambiente sano como un derecho autónomo en el sistema interamericano de derechos humanos / The right to a healthy environment as an Autonomous Right in the Inter-American Human Rights system

Digno José Montalván Zambrano

Tratados bilaterales de inversión y derechos humanos: tres posiciones desde América Latina / Bilateral investment treaties and Human Rights: three positions from Latin America 



\title{
INTRODUCCIÓN / INTRODUCTION
}

\section{ALGUNAS APORTACIONES DEL ÁMBITO LATINOAMERICANO AL DERECHO INTERNACIONAL DE LOS DERECHOS HUMANOS, ESPECIALMENTE LOS DESCA}

\author{
SOME CONTRIBUTIONS FROM THE LATIN AMERICAN REGION \\ TO INTERNATIONAL HUMAN RIGHTS LAW, ESPECIALLY ESCR
}

\author{
Ruth Martinón Quintero* \\ Universidad de La Laguna
}

El 4 de julio de 2019 se celebró el Seminario «Los derechos económicos, sociales, culturales y medioambientales (DESCA) en la jurisprudencia de la Corte Interamericana de Derechos Humanos» dentro del Campus América 2019 de la Universidad de La Laguna. De los cuatro ponentes de ese Seminario, tres colaboran en este monográfico, que aspira a ser expresión de algunas contribuciones de América Latina al Derecho internacional de los derechos humanos, con estudios sobre el derecho a la vivienda, los derechos culturales de los pueblos indígenas y el derecho al medio ambiente como derecho autónomo. El cuarto artículo versa sobre un análisis de los tratados de inversión y los derechos humanos en América Latina.

Para comprender la relevancia de estas aportaciones es importante tener en cuenta la posición que han ocupado los derechos económicos, sociales y culturales (DESC) $)^{1}$ tanto como derechos fundamentales constitucionales como formando parte del Derecho internacional de los derechos humanos. En ambos ámbitos, ha predominado la dificultad de su consideración en plano de igualdad con los derechos civiles y políticos, especialmente en lo concerniente a su justiciabilidad ${ }^{2}$.

* Doctora por la Universidad Carlos III de Madrid, es licenciada en Derecho por la UNED y en Ciencia política por la Universidad Complutense de Madrid. Actualmente, es profesora contratada doctora de Derecho internacional público y Relaciones internacionales y directora académica del Centro de Documentación Europea de la Universidad de La Laguna.

${ }^{1}$ Se ha pasado a hablar de los DESCA en lugar de los DESC por la incorporación más reciente de los derechos ambientales.

2 Respecto a la justiciabilidad de los DESCA ante la Corte Interamericana de Derechos Humanos, véanse en especial los capítulos de M.Y. Robles Garza y E. Ferrer Mac-Gregor en L.E.

DOI: https://doi.org/10.25145/j.anfade.2020.37.01

Anales de la Facultad De Derecho, 37; septiembre 2020, pp. 9-13; ISSN: e-2530-8319 
En el ámbito internacional, aunque la Declaración Universal de Derechos Humanos de 1948 abarcó todos los derechos de forma conjunta, la tensión política de la guerra fría hizo que la distinción se reflejara de manera rotunda en la aprobación por parte de la Asamblea General de Naciones Unidas, en 1966, de dos tratados diferentes: uno, el Pacto Internacional sobre Derechos Civiles y Políticos; y, otro, el Pacto Internacional sobre Derechos Económicos, Sociales y Culturales.

Esta concepción se trasladó también a los sistemas regionales de protección de derechos humanos, no solo por la división de los diferentes tipos de derechos en convenios distintos, sino porque los derechos civiles y políticos gozan de un sistema de protección más amplio y perfeccionado. Lo observamos en el caso del Consejo de Europa, y también en el Sistema Interamericano de Derechos Humanos (SIDH), aunque en ambos existen o se han desarrollado resquicios que posibilitan su justiciabilidad por el Tribunal Europeo de Derechos Humanos y por la Corte Interamericana de Derechos Humanos.

Ciertamente, en Occidente, la evolución del principio de igualdad y no discriminación no produjo un verdadero cuestionamiento de las relaciones sociales fruto del sistema económico hasta la aparición de la concepción del Estado social de Derecho, en la que 'social' hace referencia a la «corrección del individualismo clásico liberal a través de una afirmación de los llamados derechos sociales y de una realización de objetivos de justicia social»; en el cual, continúa el profesor Elías Días, el propósito es "compatibilizar en un mismo sistema dos elementos: uno, el capitalismo como forma de producción, y otro, la consecución de un bienestar social general $»^{3}$. Así, mientras los derechos civiles y políticos se atribuyen a la persona abstracta, los derechos económicos, sociales y culturales se configuran más como los derechos de la persona en su especificidad social.

Por ello, «los derechos sociales se configuran como derechos de igualdad entendida en el sentido de igualdad material o sustancial, esto es, como derechos, no a defenderse ante cualquier discriminación normativa, sino a gozar de un régimen jurídico diferenciado o desigual en atención precisamente a una desigualdad de hecho que trata de ser limitada o superada $»^{4}$.

Sin embargo, la dificultad de la compatibilización a la que hace referencia el profesor Elías Díaz abocó a la asunción implícita de la imposibilidad de incorporar todas las implicaciones jurídico-políticas del Estado social y a la concepción predominante de los DESC como derechos secundarios. De este modo, estos se han visto «limitados o postergados como consecuencia de la incidencia ideológica y fáctica

Ríos Vega e I. Spigno (dirs.), Los derechos fundamentales en el siglo XXI, tomo VI. Los derechos sociales, económicos, culturales y ambientales, Tirant lo Blanch, Ciudad de México, 2018.

3 Díaz, E., Estado de Derechos y sociedad democrática, Taurus, Madrid, 1986, pp. 84 y 92.

${ }^{4}$ Prieto SAnchís, L., "Los derechos sociales y el principio de igualdad sustantiva», Revista del Centro de Estudios Constitucionales, 22, 1995, pp. 9-57, p. 16. 
del mercado sobre la política y el derecho"s; calificados como derechos prestacionales que debían quedar «limitados a principios programáticos y cumpliendo su función como criterios de interpretativos que imponen al legislador su desarrollo, concreción y gradación ${ }^{6}$. Porque incluso cuando los derechos sociales pueden implicar una superación del inicial individualismo jurídico, especialmente en los derechos que son conquistas del movimiento obrero ${ }^{7}$, no logran subvertir la concepción individual del Derecho y de los derechos heredera de la concepción liberal que hace a cada persona dueña de sus propios actos sin atender al contexto, a los grupos sociales y a la relación de poder entre ellos.

Cuando admitimos que pese al reconocimiento y la garantía jurídicos de los derechos humanos hay grupos que por razones sociales no pueden gozar de los mismos o, al menos, no en condiciones de igualdad respecto al resto de grupos, y la pertenencia a dicho grupo no es voluntaria pero sí determina el abanico de acciones posibles del individuo, no estamos ante una discriminación que, en principio, pueda ser resuelta con el conocimiento individual de los casos que puedan llegar al sistema judicial. Es más, con frecuencia se trata de violaciones de derechos que resultan difíciles de individualizar en conductas discriminatorias determinadas porque se enmarcan en prácticas sociales amplias y difusas, no necesariamente intencionadas, por las que un grupo social se encuentra en una posición estructural, sistémica, de subordinación respecto al resto de grupos sociales.

En el ámbito del Derecho internacional, la respuesta a estos problemas se concretó en la reivindicación de la interdependencia e indivisibilidad de los derechos humanos, proclamada con rotundidad en la Conferencia sobre Derechos Humanos de Naciones Unidas de 1993: «Todos los derechos humanos son universales, indivisibles e interdependientes y están relacionados entre sí. La comunidad internacional debe tratar los derechos humanos en forma global y de manera justa y equitativa, en pie de igualdad y dándoles a todos el mismo peso» ${ }^{8}$. Esta concepción encuentra su fundamento en el basamento axiológico de todos los derechos: el principio de igualdad y dignidad de todos los seres humanos. Este, en el ámbito interno, se concreta en una concepción del Estado de Derecho como «método político-jurídico encaminado a lograr el respeto y la garantía de los derechos fundamentales del hombre, y, paralelamente, la más plena realización de las dimensiones de racionalidad y libertad real y material en que debe basarse progresivamente la convivencia humana». En esta concepción, los derechos sociales «no solo con compatibles con

5 Añón, M.J., «Derechos sociales: inconsistencia de una visión compartimentada», en Teoría de la Justicia y derechos fundamentales. Estudios en homenaje al profesor Gregorio Peces-Barba, volumen III, Dykinson, Madrid, 2008, pp. 21-46, p. 46.

${ }^{6}$ AÑón, M.J., op. cit., p. 38.

7 Barcellona, P., «Los sujetos y las normas», en Oliva, E., Problemas de legitimidad del Estado social, Trotta, Madrid, 1991, pp. 29-47, p. 33.

${ }^{8}$ Declaración y Programa de Acción de Viena, adoptado por la Conferencia Internacional sobre Derechos Humanos en Viena el 25 de junio de 1993, punto quinto.

9 DíAz, E., op. cit., p. 66. 
la democracia, sino que son un componente esencial de los valores fundamentales de la misma, no habiendo razones de peso para su postergación o falta de consideración como tales» ${ }^{10}$.

Vale la pena detenerse en la dignidad humana como fundamento de este proceso porque con independencia de la polémica de su estatus jurídico ha servido en diversos ámbitos de protección de derechos humanos para fundamentar «manifestaciones de derechos y estándares de protección que no cuelgan de derechos fundamentales positivados como tales»; por ejemplo, el derecho a un mínimo vital o existencial, o el derecho a un trato digno, especialmente, a los grupos vulnerables ${ }^{11}$.

Es en este marco general en el que encontramos las aportaciones que se recogen en este número de la revista Anales de la Facultad de Derecho. Todas ellas son aportaciones muy interesantes y abordan aspectos innovadores en el Derecho internacional de los derechos humanos.

El trabajo de la profesora Robles Garza comienza presentando el concepto de vivienda en el Derecho internacional de derechos humanos en general y en el SIDH en particular. Expone la falta de consenso sobre la aplicación directa del artículo 26 de la Convención Americana sobre Derechos Humanos $(\mathrm{CADH})^{12}$, que permite proteger los DESCA como derechos autónomos. Si bien el derecho a la vivienda nunca ha sido protegido directamente por esa vía, sino a través del mecanismo de la conexión con otros derechos. A continuación se expone la amplia jurisprudencia de la Corte IDH en la que se encuentra ese razonamiento jurídico, protegiendo el derecho a la vivienda por conexión con el derecho a la propiedad privada, el derecho a la circulación o al movimiento o el derecho a la libertad personal. Se detiene en denunciar cómo no se han cumplido la mayor parte de medidas reparadoras en materia de vivienda de esas sentencias y finaliza reivindicando sobre una amplia argumentación jurídica la justiciabilidad directa y autónoma del derecho a la vivienda a partir del artículo 26 de la CADH.

Las pecularidades de los pueblos indígenas están en el origen de algunas particularidades muy interesantes de la labor pretoriana de la Corte IDH. El profesor Gajardo Falcón se centra en la jurisprudencia de este tribunal internacional de los derechos humanos sobre los derechos culturales de estos pueblos. Presenta una sistematización de esas sentencias en función de los derechos de la CADH (derecho a la vida, derecho a las garantías judiciales, derecho a la propiedad, derecho a

10 AnNón, M. J., op. cit., p. 40.

11 Caballero Sánchez, R., "La dignidad humana como fuente atributiva de derechos fundamentales no formalizados» (2017), en Puyol Montero, José María (coord.), Studies on life, human dignity and law. Dignidad humana, vida y derecho, Tirant lo Blanch, Valencia, pp. 25-61, p. 30.

12 Artículo 26 CADH: Artículo 26. Desarrollo Progresivo. Los Estados Partes se comprometen a adoptar providencias, tanto a nivel interno como mediante la cooperación internacional, especialmente económica y técnica, para lograr progresivamente la plena efectividad de los derechos que se derivan de las normas económicas, sociales y sobre educación, ciencia y cultura, contenidas en la Carta de la Organización de los Estados Americanos, reformada por el Protocolo de Buenos Aires, en la medida de los recursos disponibles, por vía legislativa u otros medios apropiados. 
la familia y derechos de la niñez, derecho a libertad de pensamiento y de expresión) a los que se vinculan los derechos culturales. Esto, a su vez, muestra la incidencia de la cultura de los pueblos indígenas en la interpretación de esos derechos en estos casos marcados por la multiculturalidad. Sin embargo, se plantea que en el futuro es posible que se pongan de manifiesto los límites de la adaptación de los derechos a las culturas de los pueblos indígenas cuando estas atenten contra el núcleo de los derechos de la $\mathrm{CADH}$ o su protección pueda implicar la vulneración de los derechos humanos de terceros.

Digno J. Montalbán Zambrano presenta una innovación muy reciente de la Corte IDH respecto al derecho al medio ambiente sano. Durante años, este fue introducido en su jurisprudencia a través de la conexión con la vulneración de derechos civiles y políticos. En una opinión consultiva de 2017, primero, y en una sentencia de 2020, después, se admitió un derecho al medio ambiente sano autónomo, que supone la protección de la naturaleza en sí misma, sin necesidad de vincular los atentados contra ella con dańos o riesgos en las personas. El artículo explica la aproximación ecocéntrica que este planteamiento supone y la compara tanto con el antropocentrismo clásico predominante hasta ahora como con la corriente biocéntrica. El autor defiende que este cambio en los fundamentos filosóficos últimos del Derecho de los derechos humanos no constituye un debilitamiento del mismo, sino la puerta a una interpretación holística en la que se protege a la naturaleza como «inherente al ser humano no como su piloto sino como un pasajero más».

El último artículo de este monográfico lo escribe Lucas Sebastián de Erice Aranda. Aborda cómo los tratados bilaterales de inversión (TBI) pueden afectar por sus propias características y contenido estándar al respeto de los derechos humanos, primordialmente los DESCA. En especial, el autor se detiene en mostrar cómo los TBI de vieja generación generan puntos de fricción con la capacidad regulatoria del Estado en materia de derechos humanos. Se explican tres posiciones tipo de Estados latinoamericanos: la de México, que ha decidido continuar con los TBI; la de Ecuador, que ha rechazado este tipo de tratados pero sin que esté clara su posición de futuro; y la de Brasil, que nunca firmó un TBI y actualmente promueve los acuerdos de cooperación y facilitación de inversiones, en los que desaparecen las cláusulas y mecanismos más lesivos para los derechos humanos. Se defiende que en la medida en que este modelo de tratados sirve para alcanzar el objetivo de canalizar la inversión extranjera, continuar en la actualidad con los TBI tradicionales supone una decisión voluntaria y consciente por parte del Estado de limitar en gran medida su capacidad para cumplir sus obligaciones internacionales en materia de derechos humanos. 

ARTÍCULOS / ARTICLES 



\title{
PROTECCIÓN A LA VIVIENDA EN LAS SENTENCIAS DE LA CORTE INTERAMERICANA DE DERECHOS HUMANOS: ESCENARIOS Y CUMPLIMIENTO*
}

\author{
Magda Yadira Robles Garza* \\ Universidad Autónoma de Coahuila
}

\section{RESUMEN}

La protección a las personas o grupos sociales que no tienen una vivienda, o bien que, teniéndola, la han perdido por causa de guerras, desplazamientos internos o externos, violencia e inseguridad, requieren de una atención especial por parte de los Estados. Para atender este enfoque, a continuación se analizará el criterio o estándar establecido en el Sistema Interamericano de Derechos Humanos respecto a la protección de este derecho vía conexión de derechos. Las sentencias podrían exponer el estándar de protección que desde los gobiernos nacionales deben brindarse a las personas que pierden sus viviendas en estos contextos y, por otro lado, el papel del Estado en el cumplimiento de estas demandas, con la finalidad de conjeturar la declaración autónoma del derecho a la vivienda en la sede judicial de la región de las Américas.

Palabras Clave: vivienda, derechos humanos, justicia interamericana.

\section{PROTECTION OF HOUSING IN THE SENTENCES OF THE INTER-AMERICAN COURT OF HUMAN RIGHTS: SCENARIOS AND COMPLIANCE}

\section{Abstract}

Protection for people or social groups that do not have a home or who have it lost because of wars, internal or external displacement, violence and insecurity, require special attention from States. To address this approach, the criterion or standard established in the Inter-American System of Human Rights with respect to the protection of this right through the connection of rights will then be analyzed. The judgments could set out the standard of protection that from national governments must be afforded to people who lose their homes in these contexts and, on the other hand, the role of the State in complying with these claims, in order to conjecture the autonomous declaration of the right to housing in the judicial headquarters of the region of the Americas.

KEYwORDs: housing, human rights, inter-American justice. 


\section{SOBRE EL CONCEPTO DE VIVIENDA}

Los términos que comúnmente se emplean, tanto en la normatividad como en la vida cotidiana, para referirse al espacio natural o construido en el que habita temporal o permanentemente una persona o un grupo de personas ${ }^{1}$ pueden ser vivienda, vivienda digna, vivienda adecuada, o bien la vivienda razonable.

Según la perspectiva desde la que se analice el concepto serán los elementos que integren el mismo. Por ejemplo, el concepto urbano de vivienda refiere a metros cuadrados, número de habitaciones, desde esta visión subyace -sin dudala referencia a la ciudad. Desde una perspectiva ética, la vivienda referirá elementos de dignidad, a la «morada», «residencia». Desde otras miradas, la vivienda será el lugar donde confluyan los valores, costumbres, modos de ser de un grupo de personas, familias que crea bienestar para sus integrantes.

Una perspectiva diferente también puede distinguir entre el derecho al hogar del derecho a la vivienda. El primero tiene una mirada familiar y el segundo un enfoque patrimonial. También el derecho a la propiedad debe distinguirse de la vivienda, pues tener vivienda no es siempre un derecho de propiedad sobre la misma, o bien puede coincidir la propiedad en una vivienda, pero no necesariamente la segunda con la primera.

Otro debate del mismo modo interesante se presenta en la discusión respecto a que la vivienda forma parte de otro derecho más amplio como es «el derecho a un nivel de vida adecuado" como parece enunciar la Declaración Universal de los Derechos Humanos (en adelante, DUDH):

Artículo 25.

1. Toda persona tiene derecho a un nivel de vida adecuado que le asegure, así como a su familia, la salud y el bienestar, y en especial la alimentación, el vestido, la vivienda, la asistencia médica y los servicios sociales necesarios; tiene asimismo derecho a los seguros en caso de desempleo, enfermedad, invalidez, viudez, vejez u otros casos de pérdida de sus medios de subsistencia por circunstancias independientes de su voluntad.

2. La maternidad y la infancia tienen derecho a cuidados y asistencia especiales. Todos los niños, nacidos de matrimonio o fuera de matrimonio, tienen derecho a igual protección social.

* Este trabajo se ha realizado en el marco del proyecto de investigación Teorías de la justicia y derecho global de los derechos humanos (referencia PID2019-107172RB-I00), financiado por el Ministerio de Ciencia e Innovación de España.

** Doctora en Derechos Fundamentales por la Universidad Carlos III de Madrid. Profesora e investigadora del Centro de Estudios e Investigaciones Interdisciplinarios de la Universidad Autónoma de Coahuila. Actualmente, titular de la Defensoría de los Derechos Humanos Universitarios de la Universidad Autónoma de Coahuila, México. Investigadora Nacional SNI, nivel I.

1 Ferrando Salazar, E., «El derecho a una vivienda digna y adecuada», Anuario de Filosofía del Derecho, núm. IX, 1992, pp. 305-322, p. 306. 
O también en el derecho a la vida desde el punto de vista del derecho a contar con los elementos vitales para tener una existencia digna, entre ellos, la alimentación, salud, vestido, agua y vivienda ${ }^{2}$.

Igual como hace el Pacto Internacional de Derechos Económicos, Sociales y Culturales (en adelante, PIDESC) al reconocer en el artículo 11.1 «el derecho de toda persona a un nivel de vida adecuado" para sí y su familia, que incluye alimentación, vestido y vivienda adecuados, y una mejora continua de las condiciones de existencia. Los Estados Partes tomarán medidas apropiadas para asegurar la efectividad de este derecho, reconociendo a este efecto la importancia esencial de la cooperación internacional fundada en el libre consentimiento.

En definitiva, el concepto no es pacífico ni mucho menos concluyente. Al contrario, ocupa un lugar fundamental en el sistema jurídico de Naciones Unidas (en adelante ONU) a través de diferentes instituciones u órganos. Por mencionar algunos: Objetivos de Desarrollo Sostenible (ODS) número 11, respecto a lograr "ciudades y comunidades sostenibles»; ONU-Hábitat; la Relatoría Especial de ONU sobre el Derecho a la Vivienda Adecuada; el sistema de Informes Periódicos Universales, el Comité de Derechos Económicos, Sociales y Culturales de Naciones Unidas (en adelante, Comité DESC ONU), entre otras herramientas para el seguimiento y vigilancia de los compromisos de los Estados en esta temática en los niveles regionales y nacionales.

Sin embargo, a pesar de este lugar fundamental que ocupa el derecho a la vivienda tanto en el plano normativo como en el de las instituciones, se estima que millones de personas en el mundo viven en condiciones de peligro para su vida o su salud debido al hacinamiento, insalubridad y otras condiciones muy lejanas del respeto a los derechos humanos a una vida digna o un nivel de vida adecuado.

Así mismo, el mero hecho de contar con un lugar en el que residir no implica la satisfacción del derecho a la vivienda, pues, tal y como se precisa en el párrafo anterior, es necesario que se manifiesten condiciones que permitan la realización de otras necesidades como la alimentación, salud, educación, saneamiento, esparcimiento, entre otras ${ }^{3}$.

Por otro lado, el fenómeno de la migración abona la problemática de la vivienda desde la perspectiva de los desplazamientos forzosos que obligan a las personas a abandonar propiedades y formas de vida, precisamente, en un intento de poner a salvo esta.

La Relatoría Especial sobre la Vivienda Adecuada estima que 1600 millones de personas se alojan en viviendas inadecuadas y cerca de 900000 lo hacen en asentamientos informales, tanto en países de pocos recursos como en las naciones

2 Énfasis propio.

3 Sepulveda Mellado, O., «El espacio en la vivienda social y calidad de vida», Revista INVI, vol. 1, núm. 2, 1986, pp. 10-34, p. 306. 
con mayores ingresos. Esto sin contar las estadísticas sobre las personas sin techo, es decir, sin un lugar donde vivir ${ }^{4}$.

Ahora bien, tratando de reconstruir un concepto del derecho a la vivienda desde una perspectiva de derechos humanos, el primer paso sería acudir a la normatividad, es decir, el PIDESC, cuya referencia se encuentra dentro del concepto más amplio conocido como «derecho al nivel de vida adecuado».

Sin embargo, esta visión carece de contenido esencial o normativo acerca del derecho en sí mismo. Por lo que hay que buscar su configuración en otros lugares como lo dicho por la Relatoría de ONU en esta materia. Aquí explica que el derecho a tener vivienda no debe entenderse como limitada solamente a una vivienda básica. En lugar de ello, los Estados deben promover los entornos nacionales apropiados para hacer realidad este derecho (incluyendo hacer frente a las amenazas inmediatas a la vivienda), el desarrollo de políticas y prácticas para responder a las necesidades de vivienda a largo plazo por los cambios poblacionales, y la regulación de la provisión de vivienda por parte del sector privado, como lo ha sostenido la Relatoría al señalar que «los Estados deben reconocer y entender que la obligación de lograr el derecho a la vivienda recae en ellos y no puede ser delegada a los actores privados ${ }^{5}$.

La vivienda es una de las condiciones sociales básicas que determinan la igualdad y la calidad de vida de personas y ciudades. Factores como el lugar donde se ubican las viviendas, qué tan bien están diseñadas y construidas y qué tan bien se entrelazan con el tejido ambiental, social, cultural y económico influencian el diario vivir de las personas, su salud, su seguridad y su calidad de vida.

Como se aprecia, es un concepto multidimensional que requiere, adicionalmente, un análisis desde otros factores. Por mencionar alguno, el cambio climático, el desarrollo sostenible. En efecto, estos elementos afectan tanto a las generaciones actuales como a las futuras, dada la vida útil de las viviendas como estructuras físicas. Por todo esto, la vivienda es un elemento esencial para el desarrollo sostenible. Por una parte, la construcción y operación de viviendas consume una gran cantidad de recursos (suelo, energía, agua, materiales de construcción), al mismo tiempo que contamina el aire y el agua.

Por otra parte, las viviendas están expuestas a una variedad de impactos ambientales y riesgos tales como los desastres naturales y el cambio climático. Estos aspectos también adquieren una importancia considerable dentro del desarrollo sostenible. Esta compleja red de interrelaciones entre sostenibilidad y vivienda es uno de los temas principales de las políticas de viviendas sostenibles.

En suma, se trata de un concepto multivariable o que debe analizarse a partir de los elementos que lo integran. En este sentido, será importante, en principio, analizar el contenido esencial que el marco normativo ha dispuesto sobre este derecho.

${ }^{4}$ Noticias ONU, «Millones de personas viven sin techo o en casas inadecuadas, un asalto a la dignidad y la vida», 1 julio 2018. Disponible en https://news.un.org/ES/STORY/2018/07/1437721. 5 Idem. 


\subsection{Marco normativo aplicable}

La DUDH, en el ya citado artículo 25, establece el derecho a un nivel de vida adecuado, el cual comprende, entre otros, el derecho a la vivienda. Del mismo modo, el párrafo 1 del artículo 11 del PIDESC señala: «Los Estados partes reconocen el derecho de toda persona a un nivel de vida adecuado para sí y su familia, incluso alimentación, vestido y vivienda adecuados, y a una mejora continua de las condiciones de existencia».

El órgano encargado de interpretar y aplicar el PIDESC, es decir, el Comité DESC ONU, desde 1979 ha examinado informes relativos a la vivienda adecuada y examina documentación sobre la materia. A nivel normativo, de los instrumentos internacionales que abordan los diferentes aspectos del derecho a la vivienda, es el párrafo 1 del artículo 11 del PIDESC la más amplia y, sin duda, la más importante de todas las disposiciones en la materia.

También es relevante para nuestro estudio la Observación General N. ${ }^{\circ} 4^{6}$, particularmente porque establece los elementos esenciales que están en relación con este derecho. En primer lugar, la vivienda adecuada aplica a todos. Aunque sea común en los instrumentos internacionales y también en algunos textos constitucionales (como el caso mexicano), la referencia a "para sí y su familia», no se puede considerar hoy en día en el sentido de imponer una forma o estilo de vida determinado. Incluso el propio de concepto de «familia» debe ser entendido ampliamente y sin discriminación alguna.

Esto significa que tanto las personas (en su individualidad) como las familias tienen derecho a una vivienda adecuada, con independencia de la edad, situación económica, identidad sexual, afiliación a un determinado grupo, raza, etnia o de otra índole o factor. Por tanto, el derecho no está sujeto según el artículo 2 del PIDESC a ninguna forma de discriminación?

Segundo, el concepto de vivienda no es restrictivo a un lugar o cobijo. Sino un derecho a vivir en seguridad, paz y dignidad en algún sitio. Aquí la Observación General número 4 señala que este entendimiento se refiere a dos cuestiones inmersas en el concepto de vivienda: la dignidad inherente a toda persona y la vivienda debe ser adecuada.

En tal sentido, el término «adecuación» servirá para subrayar una serie de factores que hay que tener en cuenta al determinar si las viviendas pueden considerarse «adecuadas» para los efectos del PIDESC, considerando, por supuesto, los factores inherentes a cada comunidad o población como son los derechos sociales, económicos, culturales, ambientales, entre otros. Estos factores que subraya la Observación General número 4 se verán en detalle más adelante.

Otro instrumento normativo importante para la temática es la Observación General 7 emitida por el Comité DESC ONU, mediante la cual confirmó que los

${ }^{6}$ ONU, Comité DESC, Observación General núm. 4, 1991.

7 Comité DESC ONU, Observación General, Número 4, párr. 6. 
desalojos forzosos sólo pueden justificarse en las circunstancias más excepcionales y de conformidad con los principios pertinentes del derecho internacional, tales como los Principios Básicos y Directrices Sobre los Desalojos y el Desplazamiento Generados por el Desarrollo. Entre otras cosas, los Estados deben asegurar las garantías jurídicas, incluida la no discriminación, la no arbitrariedad, el debido proceso y la equidad procesal, junto con la consulta y la participación en la toma de decisiones, el acceso a los recursos, la compensación y el realojamiento adecuado ${ }^{8}$.

Un caso pertinente con esta temática tuvo que ver recientemente ${ }^{9}$, en virtud de la decisión emitida por el Comité DESC ONU en la que reconoce el derecho de los inquilinos a una vivienda adecuada cuando los residentes protestaron por los desalojos forzosos antes de un adecuado reasentamiento y rehabilitación. El Dictamen destaca la falta de ofrecimiento por parte del Estado de brindar a la familia una vivienda alternativa. Y, por otra parte, se señalan las obligaciones a cargo del Estado para proteger el derecho a una vivienda en los casos en que el desalojo esté justificado, es decir, por la falta del pago del alquiler, o bien por dańos a la propiedad. En estas situaciones, destaca el Comité DESC ONU que «es necesario que se cumplan ciertas condiciones: acceso a recursos efectivos, consulta con las personas afectadas, consideración de opciones alternativas, garantía de que ningún otro derecho será violado como consecuencia del desalojo, protección especial para los grupos vulnerables y suministro de vivienda alternativa $»^{10}$.

El Dictamen en este asunto es particularmente importante porque vuelve a afirmar la necesidad de aplicar un estándar de razonabilidad al acceder a las políticas de los Estados y para reconocer el derecho a una vivienda adecuada para todas las personas, incluyendo los inquilinos. También es útil para abordar una situación de violaciones sistémicas derivadas de medidas de austeridad adoptadas durante las crisis económicas.

En el ámbito universal debe destacarse la recepción del derecho a la vivienda adecuada en normas internacionales como la Convención Internacional sobre la Eliminación de Todas las Formas de Discriminación Racial ${ }^{11}$, la cual en el artículo 5 dice: «... los Estados partes se comprometen a prohibir y eliminar la discriminación racial en todas sus formas y a garantizar el derecho de toda persona a la igualdad ante la ley, sin distinción de raza, color y origen nacional o étnico, particularmente en el goce de los derechos siguientes:

... e)... (III) El derecho a la vivienda».

Por su parte, la Convención Internacional sobre la Eliminación de Todas las Formas de Discriminación contra la Mujer señala en el artículo 14.2.h que:

8 Villalibre Fernández, V., «El derecho a una vivienda adecuada. Un derecho del siglo XXI», Estudios de Progreso, Fundación Alternativas, núm. 64, 2011.

${ }^{9}$ Comité DESC ONU, 20 junio 2017.

${ }^{10}$ Comité DESC ONU, 20 junio 2017, párr. 15.2

${ }^{11}$ Adoptada el 21 de diciembre de 1965 y en vigor a partir del 4 de enero de 1969. 
Los Estados Partes adoptarán todas las medidas apropiadas para eliminar la discriminación de la mujer en las zonas rurales a fin de asegurar en condiciones de igualdad entre hombre y mujeres, su participación en el desarrollo rural y en sus beneficios, en en particular le asegurarán el derecho a: [...] (h) Gozar de condiciones de vida adecuados, particularmente en las esferas de vivienda, los servicios sanitarios, la electricidad y el abastecimiento de agua, el transporte y los comunicaciones.

El artículo 27 de la Convención de los Derechos del Niño expresa:

Los Estados Partes reconocen el derecho de todo niño a un nivel de vida adecuado para su desarrollo físico, mental, espiritual, moral y social. [...] 3. Los Estados partes, de acuerdo con las condiciones nacionales y con arreglos a sus medios, adoptarán medidas apropiadas para ayudar a los padres y a otras personas responsables por el niño a dar efectividad a este derecho, y en caso necesario proporcionarán asistencia material y programas de apoyo particularmente con respecto a la nutrición, el vestuario y la vivienda.

Así como la Convención sobre los Derechos de las Personas con Discapacidad establece en varios numerales el derecho de las personas con discapacidad a poder vivir en forma independiente y participar plenamente en todos los aspectos de la vida, los Estados deben adoptar medidas para asegurar su acceso al entorno físico. Estas medidas deben incluir la identificación y la eliminación de obstáculos y barreras de acceso; se aplicarán, por ejemplo, en los edificios, vías públicas, transporte, así como en escuelas, viviendas, instalaciones médicas y lugares de trabajo ${ }^{12}$. También la Convención les reconoce el derecho a un nivel de vida adecuado para ellas y sus familias, lo cual incluye alimentación, vestido y vivienda adecuada, así como el tener acceso a los programas de vivienda pública ${ }^{13}$.

Del mismo modo, otros instrumentos internacionales hacen referencia a la vivienda, como la Convención sobre el Estatuto de los Refugiados (1954), al establecer como derecho de los refugiados que se encuentren legalmente en sus territorios el trato más favorable posible en materia de vivienda (artículo 21).

Mientras que la Convención Internacional sobre la Protección de los Derechos de todos los Trabajadores Migratorios y de sus Familiares (2003) en el artículo 43.1 establace que los «trabajadores migratorios gozarán de igualdad de trato respecto de los nacionales del Estado de empleo en relación con d) acceso a la vivienda, con inclusión de los planes sociales de vivienda y la protección contra la explotación en materia de alquileres».

Hay otras disposiciones internacionales aplicables a derechos de los pueblos o comunidades indígenas que, como se verá más adelante, se encuentran estrechamente vinculadas con la tierra y el territorio como una forma de vida y, con ello, constituyen el lugar donde están sus asentamientos familiares, es decir, sus vivien-

12 Convención sobre los Derechos de las Personas con Discapacidad artículo 9.1. ${ }^{\mathrm{a}}$.

13 Convención sobre los Derechos de las Personas con Discapacidad, artículos 28.1 y 28.2.d. 
das. Especialmente relevante en esta materia es el Convenio 169 de la Organización Internacional del Trabajo (1991) en el artículo 20, referido a los derechos de los trabajadores pertenecientes a los pueblos indígenas; en particular, señala la obligación de los Estados de evitar la discriminación en el acceso a prestaciones sociales y del trabajo como la vivienda; o bien los artículos 21 y 23 de la Declaración sobre los Derechos de los Pueblos Indígenas (2007), que aluden a los derechos de los pueblos indígenas al mejoramiento de sus condiciones económicas y sociales en las esferas de educación, empleo y vivienda; así como a asegurar su participación en los programas relacionados con los temas de salud, vivienda y otros ${ }^{14}$.

En el ámbito interamericano son relevantes en primer lugar el artículo 26 de la Convención Americana sobre los Derechos Humanos, que refiere a la obligación de los Estados de adoptar las providencias necesarias para lograr progresivamente la plena efectividad de los derechos que se derivan de las normas económicas, sociales y sobre educación, ciencia y cultura contenidas en la Carta de la Organización de los Estados Americanos (en adelante, OEA).

En este sentido, el artículo 25 de la Convención Americana nos remite a la Carta de la OEA, así como al artículo XI de la Declaración Americana de los Derechos y Deberes del Hombre que expresa:

ARTículo 11. Derecho a la preservación de la salud y al bienestar.

Toda persona tiene derecho a que su salud sea preservada por medidas sanitarias y sociales, relativas a la alimentación, el vestido, la vivienda y la asistencia médica, correspondientes al nivel que permitan los recursos públicos y los de la comunidad.

Por otra parte, el texto de la Carta de la OEA, en su artículo 34 señala que:

Los Estados miembros convienen en que la igualdad de oportunidades, la eliminación de la pobreza crítica y la distribución equitativa de la riqueza y del ingreso, así como la plena participación de sus pueblos en las decisiones relativas a su propio desarrollo, son, entre otros, objetivos básicos del desarrollo integral. Para lograrlos, convienen asimismo en dedicar sus máximos esfuerzos a la consecución de las siguientes metas básicas:

k) Vivienda adecuada para todos los sectores de la población;

l) Condiciones urbanas que hagan posible una vida sana, productiva y digna ${ }^{15}$.

14 También pueden referenciarse otros instrumentos internacionales en temas de derecho internacional humanitario como los Convenios de Ginebra (1950) en los artículos 49, 85, 134, los cuales expresan los derechos de las personas que son trasladadas o evacuadas; la protección que se brinda a los bienes muebles e inmuebles para que no sean destruidos, con excepción de las destrucciones por operaciones bélicas; así como el deber de la potencia detenedora de tomar las medidas necesarias para que todas las personas sean alojadas desde el inicio del internamiento en edificios y con todas las garantías de higiene y salubridad que las protejan del clima y de la guerra.

${ }_{15}$ El énfasis es propio. 
También en el ámbito interamericano, la Convención Interamericana para la Eliminación de Todas las Formas de Discriminación contra las Personas con Discapacidad (2001) sostiene que los Estados se comprometen a adoptar las medidas necesarias para promover la prestación o suministro de bienes y servicios tales como empleo, transporte, vivienda, educación, deporte, entre otros (artículo III. 1. a). Así como otros dispositivos de la Declaración Americana sobre los Derechos de los Pueblos Indígenas (2016) en relación con la vivienda que protegen sus tierras o territorios ${ }^{16}$.

Es de notarse también la declaración expresa del derecho a la vivienda en la Convención Interamericana sobre la de los Derechos Humanos de las Personas Mayores (2015), cuyo numeral 24 señala: «Derecho a la vivienda», así como otros preceptos que indirectamente refieren a este derecho, como el artículo 12, que hace mención a los derechos de la persona mayor que recibe cuidados a largo plazo, que deberá contar, de acuerdo con este dispositivo, con un sistema integral de cuidados que le provea protección a la salud, cobertura de servicios sociales, alimentaria y nutricional, agua, vestuario y vivienda, entre otros.

El artículo 26 de dicho dispositivo señala sobre el derecho a la accesibilidad y movilidad que los Estados deben adoptar las medidas necesarias para asegurar el acceso de las personas adultas mayores a los servicios públicos y sociales como el transporte, entorno físico, las comunicaciones, así como la eliminación de barreras en las viviendas, edificios públicos, vías de comunicación, entre otros.

Para la construcción del concepto de «vivienda» al que hacen referencia estos instrumentos tanto internacionales como regionales ${ }^{17}$, los órganos e instancias de justicia del sistema universal y de los sistemas regionales han recurrido a los elementos o guías como las Observaciones Generales que se han elaborado a través del Comité DESC ONU. Estos elementos esenciales del concepto serán la guía clave para el entendimiento e interpretación de los casos que vivienda que veremos.

\subsection{Aspectos QUe INTEGRAN El CONCEPTO DE VIVIENDA ADECUADA}

Los factores que deben ser tenidos en cuenta como un mínimo deseable para la garantía del derecho a la vivienda adecuada son definidos y explicados por el Comité DESC ONU en los términos siguientes ${ }^{18}$ :

a) Seguridad jurídica de la tenencia. Se refiere al nivel de seguridad jurídica que las personas deben tener en relación con su situación de vivienda, con el fin de protección contra desalojos forzados, amenazas u hostigamiento. La protec-

16 Artículos VI, Xxv, Xxvi, XxIx, Xxx de la citada Declaración.

17 Véase Guiglia, G., «El derecho a la vivienda en la Carta Social Europea: a propósito de una reciente condena a Italia del Comité Europeo de Derechos Sociales», Revista de Derecho Político, núm. 82, 2011, pp. 543-578.

${ }^{18}$ Comité DESC ONU, OG. Número 4, párr. 8. 
ción a la vivienda puede adoptar diversas formas, tales como la propiedad legal, el alquiler o una cooperativa de vivienda.

b) Disponibilidad de servicios, materiales, instalaciones e infraestructura. Los Estados deben garantizar que las viviendas ofrecen las instalaciones necesarias para la salud, la seguridad, la comodidad y la nutrición. Esto incluye el acceso permanente a recursos naturales y comunes, el agua potable, la energía para cocinar, la calefacción e iluminación, las instalaciones sanitarias y de aseo, el almacenamiento de alimentos, la eliminación de desechos, el drenaje y los servicios de emergencia.

c) Gastos soportables. Se refiere a los gastos personales o del hogar, los cuales deberán ser de un nivel que no impida ni comprometa el logro y la satisfacción de las otras necesidades básicas, como alimentación y salud. El Estado debe adoptar las medidas necesarias para garantizar que el porcentaje de los gastos de vivienda sean coherentes con los niveles de ingreso. Por tanto, es necesario que los Estados creen subsidios, así como formas de financiación que correspondan con sus necesidades de vivienda.

d) Habitabilidad. La vivienda adecuada debe proporcionar a sus habitantes un espacio suficiente, ser segura para vivir y dar protección contra el frío, el calor, la lluvia y otros elementos de la naturaleza y riesgos estructurales. Los Estados deben prestar especial atención a la relación entre la vivienda inadecuada y las amenazas a la salud.

e) Asequibilidad. La vivienda y los costos relacionados con la vivienda deben ser proporcionales a los niveles de ingresos, y en un nivel que no comprometa otras necesidades básicas. Los Estados deberían crear subsidios de vivienda para los que no pueden costearse una, poner en marcha protecciones para los inquilinos frente a los alquileres no razonables y asegurar la disponibilidad de materiales naturales en las sociedades donde estos recursos sean las principales fuentes utilizadas para la construcción de viviendas.

f) Lugar. En muchos casos, tanto en las ciudades como en las zonas rurales, el transporte puede ser costoso y consumir mucho tiempo. La vivienda adecuada debe estar en un lugar que permita el acceso a las opciones de empleo, servicios de salud y educación y otros servicios sociales. Las casas no deben construirse en lugares peligrosos o contaminados.

g) Adecuación cultural. Los materiales de construcción de las viviendas deben estar conectados con la expresión de la identidad cultural y la diversidad de la vivienda, según corresponda a las comunidades dentro del contexto particular.

h) Accesibilidad. Todo el mundo debe tener acceso a una vivienda adecuada, especialmente los más vulnerables. Los Estados deben ofrecer vivienda prioritaria a los grupos más vulnerables. Los Estados deben elaborar planes de viviendas apropiadas para aumentar el acceso a la tierra de las personas sin hogar o los sectores empobrecidos de la sociedad.

Sin duda, uno de los elementos centrales que la Observación General N. ${ }^{\circ} 4$ señala es la debida prioridad a los grupos sociales que viven en condiciones desfavorables a través de una atención especial mediante políticas públicas o una estra- 
tegia general de vivienda que los Estados adopten, como se afirmó en la Estrategia Mundial de Vivienda. Este plan debe asegurar una consulta con las personas afectadas y su participación, incluidas las que no tienen hogar, las que han sido desalojadas y las que no tienen acceso a instalaciones básicas, o que viven en asentamientos ilegales, las que están sujetas a desahucios forzosos y los grupos de bajos ingresos ${ }^{19}$.

En este sentido, la protección a los grupos sociales que no tienen una vivienda, o bien que, teniéndola, la han perdido por causa de guerras, desplazamientos internos o externos, violencia e inseguridad, requieren de una atención especial por parte de los Estados. Para atender este enfoque, a continuación se analizará el criterio o estándar establecido en el Sistema Interamericano de Derechos Humanos respecto a la protección de este derecho en los países del continente.

\section{LA VIVIENDA EN EL SISTEMA INTERAMERICANO DE DERECHOS HUMANOS}

\subsection{Precisión respecto a la justiciabilidad de los DeSCA}

La protección a los DESCA y, en particular, el derecho a la vivienda en el sistema interamericano se establece a través de dos instrumentos normativos: la Convención Americana sobre Derechos Humanos $(\mathrm{CADH})$ a través del artículo 26 y el Protocolo Adicional a la CADH, conocido como Protocolo de San Salvador ${ }^{20}$, vía el artículo 11.

El texto del artículo 26 de la CADH señala lo siguiente:

Los Estados partes se comprometen a adoptar providencias, tanto a nivel interno como mediante la cooperación internacional, especialmente económica y técnica, para lograr progresivamente la plena efectividad de los derechos que se derivan de las normas económicas, sociales y sobre educación, ciencia y cultura, contenidas en la Carta de la Organización de los Estados Americanos, reformada por el Protocolo de Buenos Aires, en la medida de los recursos disponibles, por vía legislativa u otros medios apropiados (Convención ADH, 22 noviembre 1969).

Por su parte, el artículo 11 del Protocolo San Salvador hace una indirecta referencia a la vivienda al señalar el derecho a contar con servicios públicos básicos:

Artículo 11. Derecho a un medio ambiente sano.

1. Toda persona tiene derecho a vivir en un medio ambiente sano y a contar con. servicios públicos básicos ${ }^{21}$.

2. Los Estados Partes promoverán la protección, preservación y mejoramiento del medio ambiente.

19 Observación General Número 4, párrs. 12 y 13.

20 Protocolo adicional a la Convención Americana sobre Derechos Humanos en materia de Derechos Económicos, Sociales y Culturales (Protocolo de San Salvador).

${ }^{21}$ La cursiva es propia. 
En primer término, es relevante para nuestro estudio señalar que la situación normativa de este derecho determina la imposibilidad jurídica de su acción directa, pues la Corte IDH sólo tiene competencia para aplicar la propia Convención. Y extiende dicha competencia sólo por virtud del artículo 19.6 del Protocolo de San Salvador en lo que hace a los derechos de sindicación y a la educación. En tal sentido, aplicando la interpretación literal del texto del Protocolo, el derecho a la vivienda queda excluido de justiciabilidad directa ante los casos presentados a la Corte IDH.

En otros lugares me he referido ${ }^{22}$ a la jurisprudencia del tribunal interamericano, que elaboró, por vía de conexión e interdependencia de los derechos, una línea jurisprudencial para hacer justiciables algunos reclamos de índole económica, social o laboral, a través de su relación o conexión con el derecho a la vida o el derecho a la integridad personal ${ }^{23}$.

Por otro lado, es necesario señalar que a partir de 2017 la Corte IDH ha aplicado la norma 26 de la Convención directamente para proteger DESCA como derechos autónomos. Así lo estableció respecto al derecho al trabajo y a la estabilidad en el empleo ${ }^{24}$; el derecho a la salud tratándose de personas enfermas de VIH/SIDA ${ }^{25}$; o en el otro asunto referido al derecho a la salud pero de una persona adulta mayor ${ }^{26}$.

En 2019 dictó sentencia en la que determinó que la falta de materialización del derecho a la seguridad social por más de 27 años generó un grave perjuicio en la calidad de vida y la cobertura de salud del señor Muelle, una persona en situación de especial protección por ser persona mayor y en condición de discapacidad ${ }^{27}$. Más recientemente, la sentencia Miembros de la Asociación Lhaka Honhat (Nuestra Tierra) vs. Argentina ${ }^{28}$ declaró la vulneración a los derechos a la alimentación y al agua contra la comunidad indígena.

Sin embargo, el problema interpretativo es más complejo de acuerdo a la estructura normativa del precepto 26 de la $\mathrm{CADH}$. En otras palabras, no traslada el contenido ni la protección de los derechos a la Convención, ni al Protocolo de San Salvador, tampoco a la Declaración de los Derechos y Deberes del Hombre; lo hace a la Carta de la Organización de los Estados Americanos (OEA) y este enfoque competencial, es precisamente uno de los principales argumentos esgrimidos por

22 Robles Garza, M., «El derecho a la salud en la Corte Interamericana de Derechos Humanos (2004-2014)», en Cuestiones Constitucionales, número 35, julio-diciembre 2016, pp. 199246. ISSN para la versión electrónica: 2448-4881. Disponible en http://revistas.juridicas.unam.mx/ index.php/cuestiones-constitucionales/article/view/10496/12662.

${ }^{23}$ Artículos 4 y 5 de la CADH.

${ }^{24}$ Corte IDH, Lagos del Campo vs. Perú, 31 agosto 2017 y Corte IDH, Trabajadores Cesados de Petroperú y otros vs. Perú, 23 noviembre 2017.

25 Corte IDH, Cuscul Pivaral y otros vs. Guatemala, 23 agosto 2018.

${ }^{26}$ Corte IDH, Poblete Vilches y otros vs. Chile, 8 marzo 2018.

27 Corte IDH, Muelle Flores vs. Perú, 6 marzo 2019.

${ }^{28}$ Corte IDH, 6 febrero 2020. 
los jueces discordantes en las sentencias que declararon la vulneración del DESCA de manera autónoma.

Otro dato interesante a comentar. Este debate interpretativo ha sido producto de dos fuerzas impulsoras: por instancia de la Comisión IDH o los representantes de las víctimas, o bien por iniciativa de los propios jueces interamericanos. Hemos sido testigos de una ardua disputa en los últimos diez años respecto a la toma de postura sobre la justiciabilidad directa o indirecta de estos derechos.

Sin embargo, como he apuntado antes, en el tema de vivienda el derecho no ha sido declarado autónomo ni tampoco protegido directamente. Lo que sí ha hecho la Corte IDH hasta ahora ha sido proteger la vivienda de las víctimas y sus familiares mediante la vía de conexión gracias al argumento de la interdependencia de los derechos y la conexión entre los mismos.

Por tanto, interesa aquí mostrar una sistematización de 21 decisiones judiciales interamericanas que permita visibilizar este trabajo interpretativo respecto a la garantía y protección de la vivienda. Para ello, se analizará en el siguiente apartado a través de una doble visión la protección a la vivienda: por un lado, de manera indirecta o por vía de conexidad a través de la aplicación de la CADH, y, por el otro, a través de las medidas de reparación integral impuestas a los Estados en dichas sentencias.

Para sistematizar las sentencias se siguió esta metodología: primero, se realizó una búsqueda de las sentencias de Fondo emitidas por la Corte IDH desde su primera sentencia en 1987 hasta fecha de corte de este documento: 20 de julio de 2020. En total, se encontraron 21 sentencias cuyas temáticas centrales hacen referencia a la pérdida de la vivienda de las víctimas y/o sus familiares a través de otros derechos convencionales. Se dividieron según sea el derecho que se consideró vulnerado por la Corte IDH como el derecho a la propiedad; el derecho a la circulación o al movimiento; la libertad personal, todos de la CADH.

Segundo, en cada uno de estos rubros se analizan -a la par del tema de fondo- las 28 medidas de reparación integral impuestas a los Estados en materia habitacional. Tercero, se hace referencia de manera breve al cumplimiento de los Estados de tales medidas. Y, finalmente, en las reflexiones finales se comentan algunas voces judiciales que exponen una vía de justiciabilidad directa del derecho a la vivienda a través del artículo 26 de la Convención Americana.

\subsection{LOS ESCENARIOS DE PROTECCIÓN DE LA VIVIENDA}

\subsubsection{El derecho a la propiedad privada (artículo 21 de la CADH)}

Para nuestro análisis es relevante destacar cómo estas sentencias muestran los escenarios en los cuales el derecho a la vivienda es protegido a través de su relación o conexión con otros derechos: el derecho a la propiedad, el derecho a la circulación o residencia para los casos de desplazamiento y también el derecho a la vida privada libre de injerencias en asuntos de desaparición de personas, ejecuciones y actos de tortura o privación ilegal de la libertad, entre otros.

Para iniciar con el primer escenario, la propiedad, cabe señalar que la Corte IDH desarrolló el concepto «amplio» de propiedad dándole un giro interpretativo 
por el cual integró una valoración "comunal» o «colectiva» en ciertos asuntos referidos principalmente a los territorios de los pueblos y comunidades indígenas ${ }^{29}$.

Por tanto, aquí se presentan los asuntos en aquellos que hacen referencia al tradicional concepto de propiedad privada y su conexión con la vivienda; posteriormente, a los referidos a las comunidades y pueblos indígenas en los que el concepto de colectividad se relaciona con los lugares donde residen estas comunidades.

Respecto al primero, la propiedad privada comprende el uso y goce de bienes. La definición empleada por el Tribunal para los bienes incluye "cosas materiales apropiables, tanto muebles como inmuebles, elementos corporales o incorporales así como cualquier otro objeto inmaterial susceptible de valor, en suma, todo aquello que pueda formar parte del patrimonio de una persona $»^{30}$.

En este mismo sentido, el Alto Tribunal ha sostenido que los derechos a la vivienda y a la propiedad están vinculados como derechos humanos interdependientes, también afirma que «toda vivienda puede ser protegida mediante el derecho a la propiedad, pero no toda propiedad es necesariamente vivienda ${ }^{31}$.

En este asunto, la Corte sostuvo -apoyándose en el Comité DESC ONUque, aunque el derecho a la vivienda es el derecho de toda persona a un lugar seguro, asequible y habitable, esta concepción no comprende toda propiedad ${ }^{32}$.

Para facilitar la exposición de estos criterios de propiedad privada he optado por agrupar los casos según las temáticas que abordan los asuntos: a) desplazamientos forzados, b) desapariciones forzadas, masacres y ejecuciones arbitrarias y, finalmente, c) las comunidades indígenas.

La primera de estas temáticas son los asuntos en los que las víctimas han tenido que desplazarse del lugar donde habitan debido a la destrucción o afectaciones estructurales a la vivienda, que suponen un costo económico, además de las condiciones de movilidad o desplazamiento. En asuntos como Yarce y otras, el Tribunal se pronuncia a favor de proteger la propiedad de la víctima, así como de reparar los daños morales y económicos que sufrió su familia por motivo del desplazamiento interno que tuvieron que realizar por peligro a sus vidas ${ }^{33}$.

El desplazamiento forzado es el escenario en la jurisprudencia interamericana que señala la necesidad de proteger el derecho a la vivienda. En efecto, es posible encontrar en aquellos asuntos que plantean el apremio de las víctimas para salvaguardar su vida y la de sus familiares el tener que abandonar su lugar de residencia, su domicilio, ya sea por la destrucción de sus viviendas, por conflictos internos, por el ejercicio de su profesión, entre otras causas más.

${ }^{29}$ Corte IDH, Comunidad Mayagna (Sumo) Awas Tingni vs. Nicaragua, 31 agosto 2001, párrs. 149-152.

${ }^{30}$ Corte IDH, Salvador Chiriboga vs. Ecuador, 6 mayo 2008, párr. 55; Corte IDH, Ivcher Bronstein vs. Perú, 6 febrero 2001, párrs. 120-122.

${ }^{31}$ Corte IDH, Vereda La Esperanza vs. Colombia, 31 agosto 2017, párr. 240.

32 Comité DESC ONU, Observación General Número 4, 1991, párr. 8

33 Corte IDH, Yarce y otras vs. Colombia, 22 noviembre 2016, párrs. 55-64. 
El artículo 22 de la CADH establece que el derecho a la circulación y a la residencia es:

1. Toda persona que se halle legalmente en el territorio de un Estado tiene derecho a circular por el mismo y, a residir en él con sujeción a las disposiciones legales.

2. Toda persona tiene derecho a salir libremente de cualquier país, inclusive del propio.

3. El ejercicio de los derechos anteriores no puede ser restringido sino en virtud de una ley, en la medida indispensable en una sociedad democrática, para prevenir infracciones penales o para proteger la seguridad nacional, la seguridad o el orden públicos, la moral o la salud públicas o los derechos y libertades de los demás.

4. El ejercicio de los derechos reconocidos en el inciso 1 puede asimismo ser restringido por la ley, en zonas determinadas, por razones de interés público.

5. Nadie puede ser expulsado del territorio del Estado del cual es nacional, ni ser privado del derecho a ingresar en el mismo.

6. El extranjero que se halle legalmente en el territorio de un Estado parte en la presente Convención, sólo podrá ser expulsado de él en cumplimiento de una decisión adoptada conforme a la ley.

7. Toda persona tiene el derecho de buscar y recibir asilo en territorio extranjero en caso de persecución por delitos políticos o comunes conexos con los políticos y de acuerdo con la legislación de cada Estado y los convenios internacionales.

8. En ningún caso el extranjero puede ser expulsado o devuelto a otro país, sea o no de origen, donde su derecho a la vida o a la libertad personal está en riesgo de violación a causa de raza, nacionalidad, religión, condición social o de sus opiniones políticas.

9. Es prohibida la expulsión colectiva de extranjeros.

En este sentido, en el artículo 22 de la $\mathrm{CADH}$ debe entenderse que el desplazamiento forzado tanto interno como externo, incluso «interurbano», puede llegar a configurarse en situaciones en las cuales dicho desplazamiento es propiciado por conflictos armados, violencia generalizada o violaciones de derechos humanos.

En cualquier caso, se trata de una situación donde, además de vulnerar el derecho a la circulación o la residencia, se asocia con la afectación a otros derechos humanos como la vida, la salud, el trabajo y, por supuesto, con las condiciones de una vivienda digna, así como otros bienes como menaje de la casa, dinero, medicamentos, joyas, artículos personales como ropa, hasta ganado o cultivos ${ }^{34}$.

Por ejemplo, uno de los casos paradigmáticos en los que la Corte IDH ha aplicado este criterio es Masacres de El Mozote y lugares aledaños vs. El Salvador ${ }^{35}$. En él la Corte IDH sostuvo que los militares despojaron a las víctimas de sus pertenencias, quemaron sus viviendas y cultivos y mataron al ganado; estas acciones de miembros de la Fuerza Armada afectaron varios derechos, entre los cuales se encuentra la

${ }^{34}$ Corte IDH, Familia Barrios vs. Venezuela, 24 noviembre 2011, párrs. 148-150; Uzcátegui y otros vs. Venezuela, 3 septiembre 2012, párr. 203.

${ }_{35}$ Corte IDH, 25 octubre 2012. 
pérdida definitiva de las propiedades de sus víctimas y la destrucción de sus hogares $^{36}$. Esto llevó al Tribunal a señalar que la vulneración del artículo 22, es decir, el ser obligados a desplazarse de sus viviendas, no sólo implicó el menoscabo de los bienes materiales, sino la pérdida de las más básicas condiciones de existencia y de desmembramiento del tejido social de estos poblados ${ }^{37}$.

Para nuestro análisis es relevante destacar cómo estas sentencias muestran otro escenario donde el derecho a la vivienda es protegido a través de su relación o conexión con otros derechos, como el derecho a la vida privada libre de injerencias. Esto es, a través de estas acciones -la masacre de estos poblados- los sobrevivientes fueron forzados a salir de sus viviendas dejando a campesinos y amas de casa sin un lugar donde habitar y sin medios para subsistir ${ }^{38}$; y por otro lado, el Estado tampoco favoreció el retorno seguro y digno de la población civil sobreviviente a sus lugares de residencia durante muchos años, ni tampoco cercioró el reasentamiento voluntario en otra parte del país, como lo describe la propia sentencia ${ }^{39}$.

En lo que respecta a las medidas de reparación integral que contempla la sentencia de El Mozote, la Corte IDH ordenó a El Salvador garantizar a las víctimas desplazadas las condiciones adecuadas para el retorno a sus comunidades de origen de manera permanente e implementar un programa habitacional en las zonas afectadas por las masacres ${ }^{40}$.

En otro asunto, Vereda la Esperanza vs. Colombia ${ }^{41}$, la Corte IDH, empleando el principio iura novit curia ${ }^{42}$, desprendió tres hechos relacionados con la vivienda: por

36 Corte IDH, Masacres de El Mozote y lugares aledaños vs. El Salvador, 25 octubre 2012, párrs. 168 y 175.

${ }^{37}$ Corte IDH, Masacres de El Mozote y lugares aledaños vs. El Salvador, párr. 208. En la sentencia la perito Yáñez De La Cruz, describió: «[n]o s[ó]lo se acabó con la población civil, sino con todo el entramado social y simbólico. Destruyeron casas, y objetos significativos[.] Les despojaron de sus prendas de vestir, de los juguetes de los nińos, de sus fotos familiares, quitaron y arrasaron con todo lo significativo para ellos. Mataron y desaparecieron animales, todos relatan [s]e llevaron las vacas, las gallinas, se llevaron mis vacas, mataron a dos toros: una p[é]rdida de significación tanto afectiva como material, en el universo campesino. Tierra arrasada constituye una marca de vulneración y estigmatización de los militares que los victimarios crearon. La dimensión del horror perpetrado allá quiso acabar con la zona, con toda su gente, vaciar el territorio, expulsarles de allá». "[f]ue una lógica de exterminio, una destrucción total de los espacios sociales. [...] La masacre disolvió la identidad colectiva, al dejar un vacío social, donde la comunidad hacia sus ritos, sus intercambios afectivos, el contexto y el marco en el que se sabían parte de la comunidad» (Corte IDH, Masacres de El Mozote y lugares aledaños vs. El Salvador, párr. 180).

${ }^{38}$ Corte IDH, Masacres de El Mozote y lugares aledaños vs. El Salvador, párr. 183.

39 Corte IDH, Masacres de El Mozote y lugares aledaños vs. El Salvador, párrs. 192-193.

${ }^{40}$ Corte IDH, Masacres de El Mozote y lugares aledaños vs. El Salvador, párrs. 345 y 346.

${ }^{41}$ Corte IDH, 31 agosto 2017.

${ }^{42}$ Se intrerpreta que el juzgador posee la facultad e incluso el deber de aplicar las disposiciones jurídicas que estime convenientes al asunto, por su posición de «conocedor» del Derecho cuando las partes no lo hayan invocado de manera explícita (Corte IDH, Velasquez Rodríguez vs. Honduras, 21 julio 1989, párr. 163), entre otros asuntos. 
un lado, el allanamiento de la misma; la destrucción de las cosas muebles que estaban dentro la casa; y, finalmente, los dańos provocados a la estructura de la vivienda ${ }^{43}$.

Estas circunstancias provocaron que las familias abandonaran la vivienda trasladándose a vivir con otros miembros de la familia. En este sentido, la Corte reflexiona sobre dos aspectos claves: por un lado, los dańos estructurales causados a las viviendas, es decir, protegió estos hechos a partir del artículo 21 de la Convención diciendo que las viviendas entraban en la categoría protegida por el derecho de propiedad de bienes inmuebles. Y, por otro, el costo económico que supone su reparación o pérdida de las viviendas que no pudieron ser habitadas, así como la otra pérdida: la de las condiciones básicas de existencia digna.

En este asunto, la Corte IDH declara la vulneración de los dos derechos aquí analizados en contexto con la pérdida de las viviendas de la comunidad; sin embargo, no existen medidas de reparación específicas sobre vivienda. Lo que sí dice la sentencia es la condena al Estado de efectuar el pago de la indemnización correspondiente por daños a la propiedad privada ${ }^{44}$.

Similar respuesta da la Corte en la sentencia dictada en el asunto Masacre de Santo Domingo, pues sostuvo que la situación de desplazamiento forzado interno que enfrentaron las víctimas que resultaron heridas y sus familiares fue consecuencia de la explosión del dispositivo cluster en el caserío de Santo Domingo, además de las afectaciones psicológicas que presentaron los sobrevivientes ${ }^{45}$.

Respecto a la propiedad, tuvo por probado que los pobladores tuvieron que abandonar sus hogares y desplazarse como consecuencia de los saqueos en algunas de las viviendas y tiendas de Santo Domingo, así como daños y destrucciones a los bienes muebles e inmuebles ${ }^{46}$. A pesar de la gravedad del asunto, la sentencia no declara medidas de reparación referidas a las viviendas destruidas. La explicación es que, si bien lo solicitaron la Comisión IDH y los representantes de las víctimas, Colombia demostró acciones en vía administrativa en las que se había restituido -mediante indemnización - a la mayoría de las víctimas. La Corte dejó a salvo los derechos de cinco víctimas que no habían gozado de dichos beneficios otorgados, para que recibieran la indemnización material correspondiente ${ }^{47}$.

$\mathrm{Al}$ igual que en Santo Domingo, la sentencia del asunto Masacres de Ituango vs. Colombia ${ }^{48}$ sostuvo que la destrucción de los hogares, la privación del uso y goce de sus bienes como ganado y viviendas, además de la pérdida económica, causó pérdida de las condiciones básicas de la existencia y, con ello, declara la violación al derecho a la propiedad en conexión con el derecho a la circulación y residencia ${ }^{49}$.

${ }^{43}$ Corte IDH, Vereda La Esperanza vs. Colombia, párrs. 246-248.

${ }^{44}$ Corte IDH, Vereda La Esperanza vs. Colombia, párr. 305.

${ }^{45}$ Corte IDH, Masacre de Santo Domingo vs. Colombia, 30 noviembre 2012, párr. 267.

${ }^{46}$ Corte IDH, Masacre de Santo Domingo vs. Colombia, 30 noviembre 2012, párr. 274.

47 Corte IDH, Masacre de Santo Domingo vs. Colombia, 30 noviembre 2012, párrs. 336

y 337.

48 Corte IDH, 30 junio 2006.

49 Corte IDH, Masacres de Ituango vs. Colombia, 1 julio 2006, párr. 183. 
En este asunto, también ordena al Estado la reparación integral mediante indemnización de 6000 dólares americanos para cada una de las personas que perdieron sus viviendas ${ }^{50}$.

Para el caso de México, en los asuntos de desaparición forzada de personas, el Alto Tribunal interamericano hizo una conexión de temáticas de vivienda con la vulneración de los derechos a la vida, a la libertad personal, así como a la honra y dignidad. Por ejemplo, en el asunto Alvarado Espinoza y otros vs. México sostuvo que el Estado deberá brindar garantías de retorno o reubicación a las víctimas desplazadas que así lo requieran, mediante el otorgamiento de medidas de seguridad efectivas para un retorno digno a su lugar de residencia habitual, o bien su reasentamiento voluntario en otra parte del país ${ }^{51}$.

En particular, la sentencia acredita que los distintos grupos familiares de las personas desaparecidas en este asunto se vieron en la necesidad de realizar diversos desplazamientos en el territorio nacional y otros fuera de este y que las autoridades mexicanas tenían conocimiento de este contexto de amenazas, hostigamientos y muerte de un familiar y no dieron la protección efectiva que se requería para salvaguardar sus vidas e integridad personal; tampoco garantizó su derecho de circulación y residencia ${ }^{52}$ porque en virtud de tal contexto de violencia se vieron obligados a desplazarse, así como el derecho a la protección a la familia ${ }^{53}$ se vio vulnerado al no otorgarle la protección necesaria a pesar de contar con medidas provisionales de la propia Corte $^{54}$.

En este asunto, las medidas de reparación para los familiares de los desaparecidos ordenaron que México brindara garantías de retorno o reubicación a las víctimas desplazadas, ya sea mediante las medidas para un retorno digno a su lugar de residencia habitual, o bien otorgar un reasentamiento voluntario en otra parte del país 55 .

\subsubsection{Derechos a la vida y a la libertad personal}

En este grupo de sentencias se exponen aquellas en las que se declaró la violación al artículo 11 (protección de la honra y dignidad), pero también cita los derechos a la vida (artículo 4), el derecho a la libertad personal (artículo 7), todos de la $\mathrm{CADH}$. Los asuntos se refieren en contextos de violencia como desapariciones forzadas, masacres o privaciones ilegales y arbitrarias a la libertad personal, así como torturas o ejecuciones.

\footnotetext{
50 Corte IDH, Masacres de Ituango vs. Colombia, 1 julio 2006, párrs. 389-391.

51 Corte IDH, Alvarado Espinoza y otros vs. México, 28 noviembre 2018, párr. 277.

52 Artículo $22 \mathrm{CADH}$.

53 Artículo $17 \mathrm{CADH}$.

54 Corte IDH, Alvarado Espinoza y otros vs. México, 28 noviembre 2018, párr. 283.

55 Corte IDH, Alvarado Espinoza y otros vs. México, 28 noviembre 2012, párrs. 329-332.
} 
Es importante para lo que sigue advertir que el artículo 11 de la $\mathrm{CADH}$ protege el derecho a la honra y la dignidad en tres aspectos:

1. Toda persona tiene derecho al respeto de su honra y al reconocimiento de su dignidad.

2. Nadie puede ser objeto de injerencias arbitrarias o abusivas en su vida privada, en la de su familia, en su domicilio o en su correspondencia, ni de ataques ilegales a su honra o reputación.

3. Toda persona tiene derecho a la protección de la ley contra esas injerencias o esos ataques.

En el asunto Pueblo Bello, en 1990 un grupo de 60 personas armadas de un grupo guerrillero ingresaron a esta localidad saqueando viviendas, desalojando a los habitantes, llevándolos a la plaza del pueblo y a la iglesia, en donde eligieron a 43 hombres de una lista y los privaron de su libertad, fueron víctimas de tortura y, posteriormente, se les privó de la vida ${ }^{56}$.

En este asunto, debido a las pérdidas ocasionadas por las violaciones graves al artículo 11, la Corte IDH decretó que el Estado debe implementar un programa habitacional de vivienda adecuada para que los familiares regresen al lugar donde residían ${ }^{57}$.

Esta medida, la implementación de un "programa de vivienda» o "programa habitacional», está presente en las sentencias interamericanas como medida de reparación integral, ya sea como restitución ${ }^{58}$, o bien como satisfacción ${ }^{59}$; o incluso considerada como garantía de no repetición en asuntos que involucran a comunidades indígenas $s^{60}$.

En los asuntos que involucraron desaparición de personas ${ }^{61}$ destaco ahora el caso Comunidad Campesina Santa Bárbara vs. Perú ${ }^{62}$ porque la Corte refiere el artículo 21 relativo a la propiedad privada en este sentido: la quema de las viviendas de los miembros de esta comunidad es una violación del derecho al uso y disfrute de los bienes; sin embargo, razona diciendo que «constituye una injerencia abusiva y arbitraria en su vida privada y domicilio. Las personas que perdieron sus hogares perdieron el lugar donde desarrollaban dicha vida privada» ${ }^{63}$.

56 Corte IDH, Masacre Pueblo Bello vs. Colombia, 31 enero 2006, párr. 109.

57 Corte IDH, Masacre Pueblo Bello vs. Colombia, 31 enero 2006, párr. 276.

58 Corte IDH, Comunidad Campesina Santa Bárbara vs. Perú, 1 septiembre 2015, párrs. 300-304; Masacres de El Mozote y lugares aledaños vs. El Salvador, 25 octubre 2012, párr. 345-346.

59 Corte IDH, Masacres de Ituango vs. Colombia, 1 julio 2006, párr. 407 y Masacre Pueblo Bello vs. Colombia, 31 enero 2006, párr. 276.

${ }^{60}$ Corte IDH, Masacre Plan de Sánchez vs. Guatemala, 19 abril 2004, párr. 105.

${ }^{61}$ Corte IDH, Alvarado Espinosa y otros vs. México, 28 noviembre 2018; también en las sentencias de la comunidad de Vereda la Esperanza y las desapariciones de las masacres de Ituango y Pueblo Bello.

${ }^{62}$ Corte IDH, Comunidad Campesina Santa Bárbara vs. Perú, 1 septiembre 2015.

${ }^{63}$ Corte IDH, Comunidad Campesina Santa Bárbara vs. Perú, 1 septiembre 2015, párr. 205. 
El Tribunal condena a Perú a proveer de una vivienda adecuada a las víctimas a través de un programa habitacional que existe actualmente en el país en el plazo de un año; en caso de no cumplirse, deberá conmutar la pena por la indemnización que fija la sentencia ${ }^{64}$.

El otro asunto mexicano que también puso en evidencia el grave problema de la desaparición de personas en México es Trueba Arciniega y otros vs. México (Corte IDH, 27 noviembre 2018). Aquí no hubo proceso, sino que las partes llegaron a un acuerdo de solución amistosa que fue homologado por el Alto Tribunal a través de la sentencia que aquí se cita, en la cual se plasma la admisión total de responsabilidad del Estado mexicano y su compromiso con las víctimas -en relación con la vivienda- a través de dos medidas de satisfacción:

La primera consiste en la entrega de vivienda y de muebles a los dos familiares de la persona desaparecida (madre y hermano): a) entrega de los recursos para la compra de la vivienda en el domicilio donde vivían al momento de los hechos; y b) dicha vivienda tendrá las siguientes características: al menos cuatro habitaciones, un salón comedor, una cocina equipada, dos baños, lavandería y un patio grande. Y deberá entregarse la vivienda totalmente amueblada ${ }^{65}$.

La segunda medida que el Estado mexicano debe cumplir es la realización de las «mejoras de mantenimiento a la vivienda del señor José Tomás Trueba Loera», padre del joven Mirey Trueba, desaparecido a manos del Ejército mexicano en un contexto en el que el Estado mexicano otorgó las labores de orden público a elementos de la Fuerza Armada. En este caso, el acuerdo indica que México debe entregar una cantidad para que se realicen las mejores necesarias de su vivienda ubicada en Chihuahua de acuerdo con las visitas de inspección realizadas a dicha vivienda ${ }^{66}$. Ambas medidas deberán cumplirse en un plazo máximo de seis meses a partir de la fecha de la firma del acuerdo de solución amistosa.

\subsubsection{Derecho a la propiedad (colectiva)}

En este apartado se sistematizan las sentencias en las que la Corte IDH considera la protección a la vivienda desde la garantía al derecho a la propiedad en su modalidad «colectiva» o "comunitaria». Como se verá enseguida, los casos en los que este concepto ha sido creado ${ }^{67}-\mathrm{y}$ después desarrollado jurisprudencialmentepor la Corte fueron asuntos que involucran a comunidades y pueblos indígenas en un contexto de desplazamiento por la pérdida y/o desalojo de sus territorios.

${ }^{64}$ Corte IDH, Comunidad Campesina Santa Bárbara vs. Perú, 1 septiembre 2015, párr. 304.

${ }^{65}$ Corte IDH, Trueba Arciniega y otros vs. México, 27 noviembre 2018, párr. 47, C.2.

${ }^{66}$ Corte IDH, Trueba Arciniega y otros vs. México, 27 noviembre 2018, párr. 47, C.3.

${ }^{67} \mathrm{El}$ primer asunto en el que la Corte IDH inició la interpretación de la propiedad en su sentido "colectivo» fue en el asunto de la Comunidad Mayagna (Sumo) Awas Tingni vs. Nicaragua, 31 agosto 2001 . 
En efecto, en 2001 la Corte IDH, a través de una interpretación "evolutiva» de la normatividad internacional en materia de derechos humanos y la aplicación del artículo 29 de la CADH (en el sentido que prohíbe una interpretación restrictiva de los derechos), sostuvo que si bien el artículo 21 de la $\mathrm{CADH}$ protege la propiedad en un sentido amplio que comprende, además, "los derechos de los miembros de las comunidades indígenas en el marco de la propiedad comunal... ${ }^{68}$.

En el caso que se comenta la Corte estableció que el Estado generó condiciones que hicieron difícil el acceso a una vida digna de los miembros de la comunidad porque vieron afectada su forma de vida como consecuencia de la falta de sus tierras y la falta de acceso a los recursos naturales; además, en cuanto a su vivienda, vivieron en precariedad debido a que fueron desplazados de sus territorios ${ }^{69}$.

En este asunto, la falta de tierra, así como la carencia de los servicios mínimos como agua potable y atención médica, generaron que los miembros de esta comunidad sufrieran desempleo, analfabetismo, tasas de morbilidad, desnutrición y una marcada marginalización por causas naturales, geográficas y culturales ${ }^{70}$.

Por otro lado, el aspecto de la identidad cultural. En este ambito la Corte IDH también ha sido prolija al desarrollar una teoría sobre la cosmovisión que debe aplicarse cuando de pueblos indígenas se trata. Este entendimiento se basa en que el territorio ancestral donde habitan estas comunidades es el espacio en el cual se desarrolla y trasciende a las generaciones futuras la identidad cultural. En otras palabras, tener la propiedad de la tierra depende no sólo su subsistencia física, sino también su permanencia como unidad cultural. Es el territorio el asiento en el cual la identidad cultural, es decir, la lengua, las tradiciones, la religión, literatura, música, alimentación, costumbres y en general toda manifestación cultural, se conserva $y$, sobre todo, se transmite para las generaciones futuras de dicha comunidad.

La sentencia sostuvo que, aunque Paraguay reconoce en legislación el derecho a la propiedad comunitaria de las tierras y recursos naturales de los indígenas, el reconocimiento legal de este derecho carece de sentido si no se ha delimitado ni entregado las tierras a la comunidad por falta de medidas adecuadas, pues con ello se ha amenazado el libre desarrollo y transmisión de su cultura y prácticas tradicionales ${ }^{71}$.

A la fecha en que se redacta este documento ${ }^{72}$, la Corte IDH ha dictado 19 sentencias en las que aplicó este criterio jurisprudencia ${ }^{73}$. Ahora bien, interesa destacar aquí nueve sentencias en las que la Corte IDH hace una conexión directa del

${ }^{68}$ Corte IDH, Comunidad Mayagna (Sumo) Awas Tingni vs. Nicaragua, 31 agosto 2001, párr. 148.

${ }^{69}$ Corte IDH, Comunidad Indígena Yakye Axa vs. Paraguay, 17 junio 2001, párr. 164.

${ }^{70}$ Corte IDH, Comunidad Indígena Yakye Axa vs. Paraguay, 17 junio 2005, párr. 168.

${ }^{71}$ Corte IDH, Comunidad Indígena Yakye Axa vs. Paraguay, 17 junio 2005, párr. 148.

72 julio 2020.

73 Sobre este tema puede consultarse Cuadernillo de Jurisprudencia de la Corte Interamericana de Derechos Humanos, número 11: pueblos indígenas y tribales. Disponible en http://www. corteidh.or.cr/sitios/libros/todos/docs/cuadernillo11.pdf. 
concepto de propiedad colectiva con la protección a la vivienda de los miembros de estas comunidades indígenas por motivo de la pérdida de aquella ${ }^{74}$.

La conexión del derecho a la propiedad -en conexión con la vivienda- se hace a través de las consideraciones a los derechos a la circulación y residencia; a la vida y libertad personal como ejecuciones, privación de la vida e incluso torturas o tratos crueles y degradantes.

El grupo más numeroso (cinco casos) en el que la vivienda es protegida hace referencia conjuntamente al derecho de propiedad colectiva y las consecuencias de la vulneración del derecho a la circulación y residencia ${ }^{75}$ por diversos motivos como proyectos de desarrollo, por violencia generalizada en la zona, entre otros. Los cuatro asuntos restantes hacen referencia a la pérdida de la propiedad -y otros derechos- y el menoscabo de las condiciones necesarias para una vida digna de los miembros de las comunidades, así como para llevar a cabo prácticas y costumbres de su identidad cultural.

Respecto al segundo grupo de sentencias referido, en el asunto de la Comunidad Sawhoyamaxa vs. Paraguay ${ }^{76}$, a través de las medidas de reparación integral la Corte dispuso que

... la devolución de las tierras tradicionales a los miembros de la Comunidad Sawhoyamaxa es la medida de reparación que más se acerca a la restitutio in integrum, por lo que dispone que el Estado debe adoptar todas las medidas legislativas, administrativas y de cualquier otra índole necesarias para asegurar a los miembros de la Comunidad el derecho de propiedad sobre sus tierras tradicionales y, por lo tanto, su uso y goce.

Incluso, previó que como las tierras estaban en manos privadas, en virtud de que fueron concesionadas a una empresa particular para su explotación, el Estado deberá considerar la posibilidad de su compra o la necesidad de expropiación para lograr la devolución de las tierras ancestrales a la comunidad, o bien, si no es posible la devolución, entregarles tierras alternativas que sean suficientes para garanti-

${ }^{74}$ Para resumir este criterio interpretativo, la sentencia establece, respecto al derecho de propiedad de comunidades indígenas, lo siguiente: 1) la posesión tradicional de los indígenas sobre sus tierras tiene efectos equivalentes al título de pleno dominio que otorga el Estado; 2) la posesión tradicional otorga a los indígenas el derecho a exigir el reconocimiento oficial de propiedad y su registro; 3) los miembros de los pueblos indígenas que por causas ajenas a su voluntad han salido o perdido la posesión sus tierras tradicionales mantienen el derecho de propiedad sobre las mismas, aún a falta de título legal, salvo cuando las tierras hayan sido legítimamente trasladadas a terceros de buena fe; y 4) los miembros de los pueblos indígenas que involuntariamente han perdido la posesión de sus tierras, y éstas han sido trasladadas legítimamente a terceros inocentes, tienen el derecho de recuperarlas o a obtener otras tierras de igual extensión y calidad. Consecuentemente, la posesión no es un requisito que condicione la existencia del derecho a la recuperación de las tierras indígenas. El presente caso se encuadra dentro del último supuesto (Corte IDH, Comunidad Indígena Sawhoyamaka vs. Paraguay, 29 marzo 2006, párr. 128).

75 Artículos 21 y 22 de la CADH, respectivamente.

${ }^{76}$ Corte IDH, Comunidad Sawhoyamaxa vs. Paraguay, 29 marzo 2006, párr. 210. 
zar la forma de vida de la comunidad y, previo acuerdo de la misma ${ }^{77}$, en un plazo de tres años a partir de la notificación de la sentencia ${ }^{78}$.

En el mismo sentido, en el caso de la Comunidad Indigena Kakmok Kasek vs. Paraguay, el área reclamada por las víctimas desde 1990 es parte de su hábitat tradicional desde tiempos inmemoriales, por lo que tienen derecho a recuperar estas tierras o a obtener otras de igual extensión y calidad, de forma tal que se garantice su derecho a preservar y desarrollar su identidad cultural..$^{79}$ En las medidas de reparación, al igual que el asunto anterior, la sentencia señala que el Estado tendrá tres años para la devolución de las tierras tradicionales a los miembros de la Comunidad, ya sea por medio del procedimiento de expropiación, o bien deberá entregar tierras alternativas dentro del territorio tradicional de sus ancestros ${ }^{80}$.

En el asunto Pueblos indigenas Kuna Mandungani y Emberá de Bayano y sus miembros vs. Panamá $a^{81}$ también declaró la violación al artículo 21 en virtud de la pérdida del territorio ancestral de las comunidades. En tal sentido, la medida de reparación también fue en el sentido de establecer la obligación de Panamá de demarcar las tierras y la titulación a nombre de dichas comunidades.

En fechas más recientes, la Corte IDH dictó una sentencia histórica al declarar la vulneración de los derechos a la alimentación y al agua de la comunidad indígena Lhaka Honhat, en Argentina, a través de la aplicación directa del artículo 26 de la CADH. En lo que respecta al derecho a la propiedad colectiva, la sentencia reitera el criterio sostenido en los casos ya citados estableciendo el deber de este país de adoptar las medidas legislativas y/o de otro carácter que fueren necesarias para dotar de seguridad jurídica al derecho de propiedad comunitaria indígena ${ }^{82}$.

Respecto a comunidades indígenas que vivieron situaciones de desplazamientos, la Corte IDH dictó sentencia en el asunto Miembros de la Aldea de Chichupac y comunidades vecinas del municipio del Rabinal vs. Guatemala ${ }^{83}$, donde sostuvo que, si bien el Estado adoptó medidas como la construcción de viviendas en estas comunidades, no fueron suficientes y efectivas para garantizar a las personas desplazadas de esas comunidades la posibilidad de un retorno seguro a sus lugares de residencia habitual, o bien contar con un reasentamiento en otra parte del país, ni tampoco tuvieron una indemnización adecuada por la pérdida de sus viviendas. En este asunto, como en otros similares, dispuso como medidas de reparación el

77 Corte IDH, Comunidad Sawhoyamaxa vs. Paraguay, 29 marzo 2006, párrs. 211-212.

${ }^{78}$ Corte IDH, Comunidad Sawhoyamaxa vs. Paraguay, 29 marzo 2006, párr. 215.

${ }^{79}$ Corte IDH, Comunidad Indígena Kakmok Kasek vs. Paraguay, 24 agosto 2010, párr. 51.

${ }^{80}$ Corte IDH, Comunidad Indígena Kakmok Kasek vs. Paraguay, 24 agosto 2010, párrs. 285-286.

${ }^{81}$ Corte IDH, Pueblos indígenas Kuna Mandunganí y Emberá de Bayano y sus miembros vs. Panamá, 13 octubre 2014, párr. 232.

${ }^{82}$ Corte IDH, Miembros de la Asociación Lhaka Honhat (nuestra Tierra) vs. Argentina, 6 febrero 2020, párr. 354 .

${ }^{83}$ Corte IDH, Miembros de la Aldea de Chichupac y comunidades vecinas del municipio del Rabinal vs. Guatemala, 30 noviembre 2016, párr. 189. 
retorno colectivo a su lugar de origen de las víctimas desplazadas del pueblo indígena maya $a c h i^{84}$.

En el asunto contra Guatemala Masacre de Río Negro ${ }^{85}$, así como en el asunto de la Comunidad Afrodescendientes desplazadas de la Cuenca del Río Cacarica (Operación Génesis) vs. Colombia ${ }^{86}$, la Corte sostuvo la violación al artículo 22 de la CADH en virtud de los desplazamientos forzados de las comunidades indígenas debido a la destrucción de los hogares de los pobladores de estas comunidades, pues no sólo constituyeron pérdidas de tipo económico, también ocasionaron la pérdida de las condiciones básicas de existencia.

Por tanto, en las reparaciones, el Tribunal ordena al Estado que restituya el efectivo uso, goce y posesión de los territorios reconocidos en la normativa a las comunidades afrodescendientes agrupadas en el Consejo Comunitario del Cacarica $^{87}$, así como medidas de seguridad y vida digna de los territorios donde habitan actualmente ${ }^{88}$.

El caso de la Comunidad Moiwana vs. Suriname ${ }^{89}$, cuyos miembros fueron masacrados por las fuerzas armadas de Suriname, los que lograron escapar huyeron a bosques cercanos y algunos fueron posteriormente exiliados o desplazados en el interior del país; por tanto, la Corte declaró la vulneración de los dos derechos: la pérdida de la propiedad tradicional de la comunidad tribal y el desplazamiento forzado ${ }^{90}$.

Aquí la reparación fue en dos sentidos: por un lado, como medida de satisfacción, obligar al Estado a tomar las medidas legislativas, administrativas y de cualquier otra índole necesarias para asegurar a los miembros de la Comunidad Moiwana su derecho de propiedad sobre los territorios ancestrales de los que fueron expulsados y tener el uso y goce de dichos territorios ${ }^{11}$. Por el otro, como medida de restitución, la sentencia establece el deber del Estado de crear un Fondo de desarrollo financiado por el Estado que provea servicios sociales básicos a los miembros de la comunidad, cuando estos regresen ${ }^{92}$. Básicamente, el Fondo (de un millón doscientos mil dólares) estaría destinado a programas de salud, vivienda y educación para los miembros de la comunidad bajo la administración de un Comité de con-

${ }^{84}$ Corte IDH, Miembros de la Aldea de Chichupac y comunidades vecinas del municipio del Rabinal vs. Guatemala, 30 noviembre 2016, párr. 298.

${ }^{85}$ Corte IDH, Masacre de Río Negro vs. Guatemala, 4 octubre 2012.

${ }^{86}$ Corte IDH, Comunidad Afrodescendientes desplazadas de la Cuenca del Río Cacarica (Operación Génesis) vs. Colombia, 20 noviembre 2013, párr. 352.

${ }^{87}$ Corte IDH, Comunidad Afrodescendientes desplazadas de la Cuenca del Río Cacarica (Operación Génesis) vs. Colombia, párrs. 458-459.

${ }^{88}$ Corte IDH, Comunidad Afrodescendientes desplazadas de la Cuenca del Río Cacarica (Operación Génesis) vs. Colombia, párr. 460.

${ }^{89}$ Corte IDH, Comunidad Moiwana vs. Suriname, 15 junio 2005.

${ }^{90}$ Corte IDH, Comunidad Moiwana vs. Suriname, 15 junio 2005, párrs. 134-135.

${ }^{91}$ Corte IDH, Comunidad Moiwana vs. Suriname, 15 junio 2005, párrs. 208-211.

${ }_{92}$ Corte IDH, Comunidad Moiwana vs. Suriname, 15 junio 2005, párr. 213. 
formación mixta, es decir, de representantes de las víctimas y del Estado y un tercer miembro designado entre estos de común acuerdo ${ }^{93}$.

Otros asuntos importantes que involucraron desplazamiento de comunidades indígenas y también ejecuciones masivas son las masacres vividas en Guatemala: Masacre Plan de Sánchez ${ }^{94}$ y la Masacre de Río Negro ${ }^{95}$. Las medidas de reparación en estos asuntos tienen que ver con la reconstrucción de los lugares que habitaban antes de los episodios de violencia.

En el primer asunto, la sentencia estableció la obligación de Guatemala de un Programa de Vivienda mediante el cual se proveerá una vivienda adecuada en favor de cada uno de los sobrevivientes ${ }^{96}$. Para el segundo caso mencionado, la sentencia establece que Guatemala deberá realizar las obras de infraestructura y servicios básicos a favor de los miembros de la comunidad de Río Negro ${ }^{97}$.

Como se ha visto en estas sentencias, cuando la Corte IDH hizo la declaración de la vulneración de los derechos de propiedad -en conexión con otros como el derecho a la circulación y residencia, la libertad personal, la vida y vida privada, entre los principales-, dictó medidas de reparación a favor de las víctimas con el fin de que sean restituidos, ya sean sus territorios como en el caso de las comunidades indígenas, o bien los bienes inmuebles y muebles donde habitaban. Interesa, por tanto, verificar el grado de cumplimiento de estas sentencias en cuanto a la reparación integral de los daños ocasionados a las víctimas y sus familiares en materia habitacional.

\section{EL (IN) CUMPLIMIENTO DE LAS MEDIDAS DE REPARACIÓN INTEGRAL DE VIVIENDA EN LAS SENTENCIAS INTERAMERICANAS}

De las 21 sentencias dictadas por la Corte IDH en las que se encontró referencia a la protección a la vivienda de las víctimas se encontraron 28 medidas de reparación en materia habitacional. Sin embargo, solamente aparecen como "cumplidas totalmente» cuatro de ellas. Estas cuatro medidas cumplidas en materia de vivienda son:

1) Medida de indemnización, en la sentencia Masacre de Ituango vs. Colombia, cuyo plazo de cumplimiento fue de 55 meses y el Estado debía entregar una cantidad de 6000 dólares americanos a cada una de las víctimas para la compra de vivienda ${ }^{98}$.

93 Corte IDH, Comunidad Moiwana vs. Suriname, 15 junio 2005, párr. 212.

${ }^{4}$ Corte IDH, Masacre Plan de Sánchez vs. Guatemala, 29 abril 2004.

${ }^{5}$ Corte IDH, Masacre Río Negro vs. Guatemala, 4 octubre 2012.

${ }^{96}$ Corte IDH, Masacre Plan de Sánchez vs. Guatemala, 29 abril 2004, párr. 105.

${ }^{97}$ Corte IDH, Masacre Río Negro vs. Guatemala, 4 octubre 2012, párr. 248.

98 Corte IDH, Resolución de supervisión de cumplimiento, 28 febrero 2011. 
2) y 3) Las dos medidas dictadas en el asunto Comunidad Indígena Xákmok Kásek vs. Paraguay fueron cumplidas en cuanto a la remoción de los obstáculos para procesos de titulación ${ }^{99}$ y la segunda, la entrega de los títulos de propiedad a favor de la comunidad ${ }^{100}$.

4) La medida dictada en el asunto Defensor de Derechos Humanos y otros vs. Guatemala, referente al pago de la indemnización por los gastos ocasionados por el desplazamiento que sufrió la víctima y sus familiares ${ }^{101}$, cuya dilación demoró 26 meses.

Hay dos decisiones que tienen cumplimiento parcial ${ }^{102}$ : en el asunto Masacre de Ituango, sobre el programa de vivienda habitacional; y, la otra, en el asunto Yarce y otras vs. Colombia, respecto a la medida de indemnización para cubrir la pérdida de la propiedad privada de los familiares de las víctimas.

Por tanto, quedan 22 medidas de reparación en materia habitacional «pendientes de cumplimiento». Esta categoría alude a la falta total del acatamiento del Estado. La tabla 1 habla por sí sola de la situación respecto a las medidas de reparación a las que se ha hecho referencia.

\begin{tabular}{lcccc}
\hline \multicolumn{1}{c}{ PAís } & $\begin{array}{c}\text { NúmERo DE } \\
\text { MEDIDAS }\end{array}$ & Cumplidas & $\begin{array}{c}\text { PENDIENTES DE } \\
\text { CUMPLIMIENTO }\end{array}$ & $\begin{array}{c}\text { Cumplimiento } \\
\text { PARCIAL }\end{array}$ \\
\hline Argentina & 1 & 0 & 1 & 0 \\
\hline Colombia & 8 & 1 & 5 & 2 \\
\hline El Salvador & 1 & 0 & 1 & 0 \\
\hline Guatemala & 4 & 1 & 3 & 0 \\
\hline México & 2 & 0 & 2 & 0 \\
\hline Paraguay & 6 & 2 & 4 & 0 \\
\hline Panamá & 2 & 0 & 2 & 0 \\
\hline Perú & 1 & 0 & 1 & 0 \\
\hline Suriname & 1 & 0 & 1 & 0 \\
\hline Venezuela & 2 & 0 & 2 & 0 \\
\hline Total & 28 & 4 & 22 & 2 \\
\hline
\end{tabular}

Fuente: elaboración propia, con información obtenida de la página oficial de la Corte IDH.

99 Corte IDH, Resolución de supervisión de cumplimiento, 24 junio 2012.

100 Corte IDH, Resolución de supervisión de cumplimiento, 30 agosto 2017.

101 Corte IDH, Resolución de supervisión de cumplimiento, 22 noviembre 2016.

102 Este criterio lo otorga el Tribunal cuando el Estado ha demostrado dar trámite o cumplimiento a la medida ordenada por él; sin embargo, a juicio de la propia Corte o por desacuerdo de los víctimas no se puede considerar cumplida totalmente la medida. 


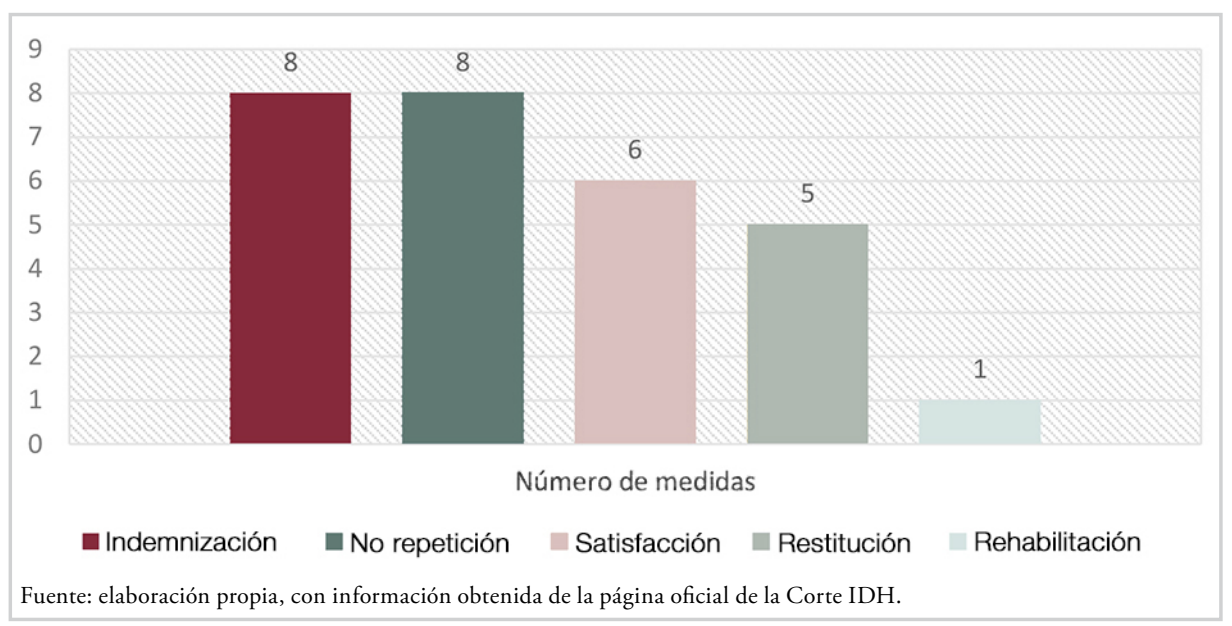

Gráfica 1. Medidas de reparación en materia de vivienda.

Otro dato que podría ser útil en cuanto a la forma en que la Corte IDH identifica las medidas de reparación que involucran la vivienda y los bienes perdidos por las víctimas es la categoría en la cual es incluida la medida. Como es sabido, en materia de reparación integra ${ }^{103}$, la doctrina jurisprudencial interamericana ha hecho un catálogo de los tipos de medidas: indemnización, rehabilitación, garantías de no repetición, satisfacción y restitución. Y también es conocido que la medida que más cumplen es la indemnización, debido a que puede ser acelerado su cumplimiento al otorgar un suma determinada de dinero a las víctimas, cuando el caso así lo permita. Al respecto la gráfica 1 . Número de medidas por rubro.

Cada uno de ellos refiere a un aspecto particular de la medida; por ejemplo, en la primera categoría se engloban los gastos materiales e inmateriales por motivo de la sustanciación del proceso judicial llevado a cabo por la víctima y sus familiares y, además, regularmente la Corte IDH incluye aquí las pérdidas en materia de bienes muebles e inmuebles. No por ello, de las 28 medidas de reparación en materia de vivienda se ubican en este rubro ocho de dichas medidas.

En cuanto a la rehabilitación (una medida), consiste en una forma de reparar a las víctimas como el otorgar el título de propiedad a la Comunidad Kakmok Kásek de las tierras que habían perdido. Respecto a las garantías de no repetición, la Corte IDH ha tenido un criterio variable. En el caso de estas sentencias, encontra-

103 Calderón Gamboa, J.F., «La reparación integral en la jurisprudencia de la Corte Interamericana de Derechos Humanos: estándares aplicables al nuevo paradigma mexicano", Derechos Humanos en la Constitución: Comentarios de Jurisprudencia Constitucional e interamericana, Instituto de Investigaciones Jurídicas-UNAM, 2013, pp. 145-219. 
mos ocho medidas de no repetición. Los ejemplos son variados: adopción de medidas legislativas y administrativas para que las comunidades indígenas no vuelvan a perder sus propiedades comunales ${ }^{104}$, otorgamiento de títulos de propiedad colectiva ${ }^{105}$, garantías de retorno o de reubicación a las víctimas por desplazamiento forzoso y pérdida de vivienda ${ }^{106}$, o bien programas habitacionales para las comunidades que vieron destruidas sus viviendas y hogares por motivo de la violencia ${ }^{107}$.

Las medidas de restitución (cinco medidas) hacen referencia a la entrega a las víctimas de lo perdido, por ejemplo, entrega de alpacas, ganado y viviendas ${ }^{108}$, viviendas para el retorno seguro ${ }^{109}$. Finalmente, en el rubro de "satisfacción», las seis medidas que aparecen en este grupo de sentencias hacen referencia a deberes del Estado en relación con suministro de bienes y servicios básicos para la vivienda para los habitantes de la Comunidad indígena Sawhoyamaxa y la Comunidad de Río Negro; y, un programa habitacional para los sobrevivientes y familiares de las víctimas de la Masacre Pueblo Bello y Masacre de Ituango. La tabla 2 presenta la anterior información en forma sistematizada.

\begin{tabular}{|c|c|c|c|c|}
\hline \multicolumn{5}{|c|}{ TABLA 2. NÚMERO DE MEDIDAS POR RUBRO } \\
\hline Rubro & $\begin{array}{l}\text { NÚMERO DE } \\
\text { MEDIDAS }\end{array}$ & Cumplidas & $\begin{array}{l}\text { Pendientes de } \\
\text { Cumplimiento }\end{array}$ & $\begin{array}{c}\text { Cumplimiento } \\
\text { PARCial }\end{array}$ \\
\hline Indemnización & 8 & 2 & 5 & 1 \\
\hline Rehabilitación & 1 & 1 & 0 & 0 \\
\hline No repetición & 8 & 1 & 7 & 0 \\
\hline Restitución & 5 & 0 & 5 & 0 \\
\hline Satisfacción & 6 & 0 & 5 & 1 \\
\hline Total & 28 & 4 & 22 & 2 \\
\hline
\end{tabular}

Fuente: elaboración propia, con información obtenida de la página oficial de la Corte IDH.

104 Corte IDH, Miembros de la Asociación Lhaka Honhat (Nuestra Tierra) vs. Argentina, 6 febrero 2020.

105 Corte IDH, Pueblos Indígenas Kuna de Mandunganí y Emberá de Bayano y sus miembros vs. Panamá, 13 octubre 2014

106 Corte IDH, Alvarado Espinosa vs. México, 28 noviembre 2018.

107 Corte IDH, Masacre Plan de Sánchez vs. Guatemala, 29 abril 2004.

108 Corte IDH, Comunidad Campesina Santa Bárbara vs. Perú, 1 octubre 2015.

109 Corte IDH, en los casos de Masacres de El Mozote y lugares aledaños, Comunidad de Afrodescendientes desplazadas de la Cuenca del Río Cacarica (Operación Génesis), Miembros de la Aldea de Chichupac y comunidades vecinas del municipio del Rabinal. 


\section{REFLEXIONES FINALES: VOCES PARA LA CONSIDERACIÓN DE UN DERECHO AUTÓNOMO DE LA VIVIENDA EN EL SISTEMA INTERAMERICANO}

Hasta aquí he presentado una sistematización del panorama jurisprudencial de los casos en los que la Corte IDH ha realizado una protección a la vivienda mediante la técnica de conexión con otros derechos, particularmente con el derecho a la propiedad y con el derecho a la circulación y residencia, ambos reconocidos por los artículos 21 y 22 de la Convención.

Para realizar las últimas consideraciones a esta temática estimo relevante señalar algunos planteamientos judiciales en el sistema interamericano que llaman a revisar la justiciabilidad directa del derecho a la vivienda mediante la interpretación al artículo 26 de la Convención, como ya lo ha hecho el Tribunal de San José en asuntos relacionados con el derecho a la salud, al empleo o la seguridad social.

Los argumentos en esta temática van en el mismo sentido y dirección que los anteriores asuntos de DESCA reconocidos en sede interamericana a partir de la interpretación del artículo 26 de la Convención. Por tanto, más allá de reiterar dichos planteamientos aquí me parece que existen otros singulares motivos para considerar el eventual reconocimiento autónomo del derecho a la vivienda en una impronta no muy lejana y, sobre todo, por las consecuencias para la protección a este derecho en la región, como un auténtico derecho humano.

Uno de estos motivos y, en mi opinión, el más relevante -por lo controvertido que resulta- es aquel que descansa en la falta de protección y reconocimiento expreso del derecho a la vivienda tanto en la Convención como en el Protocolo San Salvador. El argumento sostiene que, al asumir jurisdiccionalmente la protección del derecho a la vivienda, se sigue la interpretación judicial adoptada en los casos relativos a la salud, alimentación e incluso del agua, es decir, a través de la interpretación evolutiva y la aplicación del iuris corpus interamericano, tal como lo ha sostenido en estos casos el Alto Tribunal interamericano.

En el caso Yarce y otras vs. Colombia, el voto concurrente del juez Ferrer Mac-Gregor sostuvo que el asunto destaca por dos hechos: la labor de defensoras de derechos humanos, es decir, la protección a las mujeres y su labor; y, por otro lado, la pérdida de la vivienda en los contextos de desplazamiento forzado interno que se expone en el caso mencionado.

Este mismo sentido judicial fue reiterado en la sentencia Vereda La Esperanza vs. Colombia ${ }^{110}$. En este asunto, relativo a una comunidad cuyos miembros fueron privados de la vida, desaparecidos niños, niñas y adultos y ejecuciones arbitrarias, en el que los sobrevivientes fueron forzados a dejar sus viviendas, campos, cultivos y ganados. En este caso se consideró de especial gravedad la pérdida de las condiciones de existencia digna de las víctimas y su situación de vulnerabilidad.

110 Voto concurrente del juez Eduardo Ferrer Mac-Gregor Poisot en el caso Vereda La Esperanza vs. Colombia, 31 agosto 2017, párrs. 7 y ss. 
Otro argumento que se emplea para sostener la viabilidad de la tesis a favor de la justiciabilidad hace referencia al desarrollo que la Corte IDH ha realizado del concepto de propiedad (tanto privada como comunal), como protección de los bienes que forman parte del patrimonio de las personas, tanto muebles como inmuebles.

Sin embargo, para separarse de este criterio el voto del juez Mac-Gregor expone que el concepto de «vivienda" puede quedar protegido dentro del derecho de propiedad, pero no necesariamente toda propiedad es necesariamente vivienda ${ }^{111}$. Este discernimiento sigue a lo establecido por la Comité DESC ONU al expresar que el derecho a la vivienda «es el derecho de toda persona a un hogar seguro, asequible y habitable» ${ }^{112}$, lo cual no siempre comprende a la propiedad. En tal sentido, pueden ubicarse en esta línea argumentativa los casos en que las destrucciones o afectaciones a la vivienda y los bienes que la integran que sean atribuibles al Estado deben ser protegidos por un derecho autónomo que así lo comprenda.

Otro argumento que se ha sostenido tiene que ver con la «interdependencia» de los derechos humanos. La sentencia sobre el caso Lhaka Honhat es muestra de esto. Sostuvo el Tribunal que en el caso de los pueblos indígenas la pérdida de territorios o tierras no necesariamente presenta relación con el derecho de propiedad; incluso plantea que pueden existir lesiones a otros derechos que, vinculados con el territorio, pueden ser analizados desde un enfoque distinto al de la propiedad, como lo hizo en la sentencia antes mencionada al declarar la violación de los derechos a la alimentación y al agua de la comunidad ${ }^{113}$ partiendo de un examen desde la óptica del artículo 26 ya citado.

Una reflexión final tendría también como propósito llamar la atención sobre dos aspectos para la protección del derecho a la vivienda. El primer aspecto tiene que ver con las medidas de reparación impuestas por la Corte IDH para reparar los daños ocasionados tanto a las víctimas como a sus familiares. Aquí se ha visto que las sentencias imponen a los Estados obligaciones en torno a la devolución de sus tierras, al establecimiento de programas habitacionales, a la compensación económica por la pérdida de las viviendas y sus muebles, entre otras medidas.

Sin embargo, y esto nos lleva al segundo aspecto, el cumplimiento de estas medidas queda muy debajo del porcentaje de cumplimiento de las sentencias de la Corte IDH ${ }^{114}$.

Las sentencias que han visto cumplidas las medidas de reparación en materia habitacional se desahogan mejor -más rápido- vía la indemnización. La experiencia en las medidas de no repetición o satisfacción en la Corte IDH dice que los

${ }_{111}$ Voto concurrente del juez Eduardo Ferrer Mac-Gregor Poisot en el caso Vereda La Esperanza vs. Colombia, 31 agosto 2017, párr. 24.

112 Voto concurrente del juez Eduardo Ferrer Mac-Gregor Poisot en el caso Vereda La Esperanza vs. Colombia, 31 agosto 2017, párr. 25.

113 Voto concurrente del juez Eduardo Ferrer Mac-Gregor Poisot en el caso Vereda La Esperanza vs. Colombia, 31 agosto 2017, párr. 40.

114 Academia Interamericana de Derechos Humanos, Informe de Ejecución de Sentencias de la Corte IDH 1988-2018, México, 2019. 
Estados demoran más en tomar las medidas tanto legislativas cuanto administrativas para llevar a cabo sus deberes. Las medidas de política pública, de presupuesto, de involucramiento con las demás ramas del Estado dicen que la demora será mayor. Tratándose de un bien básico para la vida digna, como es el tener un «techo» donde vivir, no parecen ser el remedio más efectivo para las víctimas.

Recibido: septiembre de 2020; ACEPTADo: diciembre de 2020 



\title{
LOS DERECHOS CULTURALES DE LOS PUEBLOS INDÍGENAS EN LA JURISPRUDENCIA DE LA CORTE INTERAMERICANA DE DERECHOS HUMANOS*
}

\author{
Jaime Gajardo Falcón** \\ Universidad Diego Portales (Chile)
}

\section{RESUMEN}

El presente trabajo, en primer lugar, sistematiza la jurisprudencia de la Corte Interamericana de Derechos Humanos sobre los derechos culturales de los pueblos indígenas. En segundo lugar, analiza la incidencia que tiene la cultura de los pueblos indígenas en la interpretación de un conjunto de derechos asociados a la Convención Americana de Derechos Humanos. En tercer lugar, en el trabajo se propone una clasificación de la jurisprudencia que ha recaído sobre los derechos culturales de los pueblos indígenas. Finalmente, se exponen algunas conclusiones a las que se ha podido arribar del análisis jurisprudencial.

Palabras Clave: Corte Interamericana de Derechos Humanos, derechos culturales, multiculturalismo y pueblos indígenas.

\author{
CULTURAL RIGHTS IN THE JURISPRUDENCE \\ OF THE INTER-AMERICAN COURT OF HUMAN RIGHTS
}

\section{Abstract}

This paper, in the first place, systematizes the jurisprudence of the Inter-American Court of Human Rights on the cultural rights of indigenous peoples. Second, it analyzes the impact that the culture of indigenous peoples has on the interpretation of a set of rights associated with the American Convention on Human Rights. Third, the work proposes a classification of the jurisprudence on the cultural rights of indigenous peoples. Finally, some conclusions are presented.

KeYwords: Inter-American Court of Human Rights, cultural rights, multiculturalism and indigenous peoples. 


\section{INTRODUCCIÓN}

Los diferentes países que conforman el continente americano se encuentran integrados por diversas culturas y sus sociedades son multiculturales y multiétnicas. Así, la realidad cultural americana tiene un espesor cultural relevante que "colorea el mapa de la diversidad cultural del continente y tiene una función de argamasa: constituye a la vez un fenómeno de cohesión social y de apelación identitaria» ${ }^{1}$.

En ese sentido, la principal fuente de la diversidad cultural del continente americano viene dada por la presencia de diferentes pueblos y comunidades indígenas en prácticamente todos los Estados del continente. En la mayoría de los países latinoamericanos la población indígena se encuentra entre el 3\% y el 10\% de la población. Por su parte, México, Bolivia, Guatemala, Perú y Colombia reunen al 87\% de indígenas del continente. En ese sentido, destacan por tener una alta población indígena los siguientes países: Bolivia $(41 \%)^{2}$, Guatemala $(48 \%)^{3}$ y Perú $(25,8 \%)^{4}$. Así, en términos porcentuales se calcula que aproximadamente un $10 \%$ del total de la población de América Latina y el Caribe (50 millones de personas aproximadamente) se autoidentifican como parte de un pueblo indígena.

* Una versión preliminar del presente trabajo fue presentada en segunda sesión del Campus América que se celebró en el mes de julio de 2019 en la Universidad de La Laguna. Agradezco a quienes participaron de dicha sesión por sus valiosos comentarios, críticas y sugerencias. Este trabajo forma parte del proyecto FONDECYT de iniciación a la investigación número 11190460 titulado «Modelos de interpretación de los derechos fundamentales en contextos multiculturales y sus implicancias en los sistemas constitucionales», de la Agencia Nacional de Investigación y Desarrollo del Gobierno de Chile; y del proyecto de investigación «Jueces en Democracia. La filosofía política de la Corte Interamericana de Derechos Humanos», del Ministerio de Ciencia e Innovación de España (DER2016-79805-P, AEI/FEDER, UE).

** Abogado y magíster en Derecho, con mención en Derecho Público, Universidad de Chile. Máster en Gobernanza y Derechos Humanos, Universidad Autónoma de Madrid. Máster en Derecho Constitucional, Centro de Estudios Políticos y Constitucionales. Doctor en Derecho, Universidad Autónoma de Madrid. Profesor de la Cátedra de Derecho Constitucional, Universidad Diego Portales (Chile).

${ }^{1}$ Cfr. Subercaseaux, B., Nación y Cultura en América Latina. Diversidad cultural y Globalización, LOM Ediciones, Santiago, 2002, p. 16.

2 Según el Censo Nacional de 2012, 2,8 millones de personas mayores de 15 años, o el $41 \%$ de la población total, son de origen indígena. Los datos se pueden consultar en https://www. ine.gob.bo/index.php/censos-y-banco-de-datos/censos/.

${ }^{3}$ Datos del censo del año 2018, disponible en https://www.censopoblacion.gt/cuantossomos. Sin embargo, la Comisión Interamericana de Derechos Humanos ha dado cuenta de otras estadísticas que señalan que la población indígena que habita en Guatemala es del 60\%. Véase Informe CIDH, «Situación de los derechos humanos en Guatemala: Diversidad, desigualdad y exclusión», 2015, OEA/Ser.L/V/II.Doc. 43/15, p. 23.

${ }^{4}$ La caracterización estadística de la República de Perú, realizada por en el censo de 2017, señala que en Perú apróximadamente siete millones de personas (esto es, un 25,8\% de la población) se autoidentificó como parte de un pueblo indígena y un 3,6\% de la población como afroperuano. Los datos se pueden consultar en https://wwwl.inei.gob.pe/estadisticas/censos/. 
Debido a lo anterior, desde comienzos de la década de los ochenta, principalmente, en América Latina se viene desarrollando un fenómeno que se ha denominado la "emergencia indígena»" que ha implicado un resurgimiento de la cuestión indígena en el continente y grandes desafíos para los diferentes sistemas políticos y jurídicos. Para José Bengoa la demanda de los pueblos indígenas es profunda y radical; no sólo implica derechos para su grupo, sino que cuestiona los cimientos del Estado Nación en todo el continente ${ }^{6}$ y el modelo de desarrollo económico ligado a la explotación de los recursos naturales que se encuentran, principalmente, en los territorios que han ocupado ancestralmente los pueblos indígenas y sus comunidades ${ }^{7}$.

$\mathrm{La}$ «emergencia indígena», entre otras cosas, ha tenido un fuerte impacto en los sistemas normativos del continente, los que junto con suscribir y ratificar los principales instrumentos internacionales en materia indígena ${ }^{8}$ han constitucionalizado, con diferentes grados y profundidades, un conjunto de derechos específicos para los pueblos indígenas y sus miembros?.

De igual forma, el sistema interamericano de protección de los derechos humanos se ha destacado por dar una especial protección a los derechos de los pueblos indígenas, tanto en el trabajo de la Comisión Interamericana de Derechos Humanos (CIDH) como en la jurisprudencia de la Corte Interamericana de Derechos Humanos (Corte IDH). Así, en el presente trabajo me centraré en clasificar y analizar la jurisprudencia de la Corte IDH sobre los derechos culturales de los pueblos indígenas, la que ha sido abundante y referida a un gran conjunto de temas. Luego de analizar y clasificar la jurisprudencia señalada, finalizaré el trabajo con algunas conclusiones que se pueden obtener al respecto.

5 Véase Bengoa, J., La emergencia indígena en América Latina, Fondo de Cultura Económica, Santiago, 2007.

${ }^{6}$ Idem.

7 Al respecto, véase Gajardo, J., «El Derecho Humano a la Propiedad Comunal Indígena y el Modelo de Desarrollo en América Latina. Un Estudio de Casos», en Pele, A., Cittadino, G., Masbernat, P. y Modesto de Gasperín, R., Direitos Humanos e Neoliberalismo, Lumen Juris, Rio de Janiero, 2018, pp. 113-136. Asimismo, véase Martí i Puig, S., Wright, C., Aylwin, J. y Yáñez, N., Entre el desarrollo y el buen vivir, Catarata, Madrid, 2013.

${ }^{8}$ Sobre el derecho internacional de los pueblos indígenas, entre otros, véase 1) AnAYa, J., Los pueblos indigenas en el derecho internacional, Trotta, Madrid, 2005; 2) MACKAY, F., Los derechos de los pueblos indigenas en el sistema internacional, FIDH, Lima, 1999; 3) Aguilar, G., Dinámica internacional de la cuestión indígena, Librotecnia, Santiago, 2007.

${ }^{9}$ Sobre la constitucionalización de los derechos de los pueblos indígenas, entre otros, ver 1) Torbisco, N., «Derechos indígenas: reconocimiento y desafíos para la democracia constitucional y para los derechos humanos", en Hierro, L., Un conflicto de derechos: autonomía individual v. autonomía colectiva, Marcial Pons, Madrid, 2014, pp. 81-127; 2) YRIGoYen, R., «El horizonte del constitucionalismo pluralista: del multiculturalismo a la descolonización", en El derecho en América Latina. Un mapa para el pensamiento jurídico del siglo XXI, Siglo XXI, Buenos Aires 2011, pp. 139159; 3) Gajardo, J., "El reconocimiento constitucional de los pueblos indígenas en América Latina. Una revisión a los modelos y una propuesta de clasificación», en Gajardo, J. y ZúñIga, F., Constitucionalismo y procesos constituyentes. Vol. 2. Una revisión crítica al nuevo constitucionalismo latinoamericano, Thomson Reuters, Santiago, 2019, pp. 67-86. 


\section{JURISPRUDENCIA DE LA CORTE INTERAMERICANA DE DERECHOS HUMANOS SOBRE DERECHOS CULTURALES DE LOS PUEBLOS INDÍGENAS}

En este acápite abordaré la jurisprudencia de la Corte IDH sobre aspectos ligados a la cultura de fuente indígena. Los derechos culturales de los pueblos indígenas son una manifestación del principio de integridad cultural y consisten en el derecho de los pueblos indígenas y sus miembros de mantener y desarrollar libremente sus identidades culturales en coexistencia con otros sectores de la humanidad ${ }^{10}$.

Por su parte, los derechos culturales de los pueblos indígenas se encuentran recogidos, entre otros, tanto en el Convenio n. ${ }^{\circ} 169$ de la Organización Internacional del Trabajo (OIT) sobre Pueblos Indígenas y Tribales en Países Independientes como en la Declaración de las Naciones Unidas sobre los derechos de los pueblos indígenas y en la Declaración Americana sobre los derechos de los pueblos indígenas ${ }^{11}$.

Así, la jurisprudencia de la Corte IDH la agruparé en aquellos casos que dicen relación con aspectos culturales que se derivan del contenido del derecho a la vida ${ }^{12}$; del derecho a las garantías judiciales ${ }^{13}$; del derecho a la propiedad comunal ${ }^{14}$; del derecho a la familia ${ }^{15} \mathrm{y}$ de los derechos de la nińez indígena ${ }^{16}$; del derecho a libertad de pensamiento y de expresión ${ }^{17}$; y en cuanto a las medidas de reparación ${ }^{18}$.

${ }_{10} \mathrm{Al}$ respecto, véase Anaya, J., Los pueblos indigenas en el derecho internacional, Trotta, Madrid, 2005, pp. 179-202.

${ }^{11}$ Los derechos culturales de los pueblos indígenas y el principio de integridad cultural se encuentran reconocidos en los artículos 11 a 17 del Convenio n. ${ }^{\circ} 169$ de la OIT. En términos similares, tanto la Declaración de la ONU como la americana sobre derechos de los pueblos indígenas establecen los derechos culturales y el principio de integridad en el artículo 13 y siguientes, y en los artículos XXv y siguientes, de los respectivos instrumentos jurídicos internacionales.

12 En este punto revisaré la jurisprudencia de la Corte IDH recaída en los siguientes casos: a) caso Bámaca Velásquez con Guatemala (2000); b) caso Moiwana con Surinam (2005); c) caso Masacres de Río Negro con Guatemala (2012); d) caso Yakye Axa con Paraguay (2005); e) caso Sawhoyamaxa con Paraguay (2006); f) caso Xákmok Kásek con Paraguay (2010).

${ }_{13}$ En este punto revisaré la jurisprudencia de la Corte IDH recaída en los siguientes casos: a) caso Tiu Tojin con Guatemala (2008); b) caso Rosendo Cantú y otra con México (2010).

${ }^{14}$ En este punto revisaré la jurisprudencia de la Corte IDH recaída en los siguientes casos: a) caso Awas Tingi con Nicaragua (2000); b) caso Yakye Axa con Paraguay (2005); d) caso Sawhoyamaxa con Paraguay (2006); e) caso Xákmok Kásek con Paraguay (2010). Asimismo, se debe tener en consideración CIDH (2004). Informe caso Comunidades Indígenas Mayas del Distrito de Toledo (Belice).

${ }_{15}$ En este punto revisaré la jurisprudencia de la Corte IDH recaída en los siguientes casos: a) Chitay Nech y otro con Guatemala (2010); b) Norín Catrimán y otros con Chile (2014).

${ }^{16}$ En este punto revisaré la jurisprudencia de la Corte IDH recaída en los siguientes casos: a) caso Xákmok Kásek con Paraguay (2010); b) Chitay Nech y otro con Guatemala (2010); c) caso Rosendo Cantú y otra con México (2010); d) caso Masacres de Río Negro con Guatemala (2012).

${ }_{17}$ En este punto revisaré la jurisprudencia de la Corte IDH recaída en el caso López Álvarez con Honduras (2006).

${ }^{18}$ En este punto revisaré la jurisprudencia de la Corte IDH recaída en los siguientes casos: a) caso Aleoboetoe con Surinam (1993); b) caso Awas Tingi con Nicaragua (2000); c) caso Plan de Sánchez con Guatemala (2004); d) caso Moiwana con Surinam (2005). 
La jurisprudencia de la Corte IDH en este punto la dividiré en dos temáticas: 1) aquella que se relaciona con el derecho a una vida digna; 2 ) la que dice relación con aspectos culturales a considerar en el entierro y trato de un cadáver conforme a la cultura indígena ${ }^{19}$. Sobre el primer punto, esto es, la jurisprudencia que se relaciona con el derecho a una vida digna, podemos señalar los siguientes casos: a) caso Yakye Axa con Paraguay (2005); b) caso Sawhoyamaxa con Paraguay (2006); c) caso Xákmok Kásek con Paraguay (2010).

En el caso Yakye Axa con Paraguay (2005) la Corte IDH señaló que las comunidades indígenas habían visto vulnerado su derecho a la vida y vivían en condiciones de miseria extrema debido a la falta de tierra y acceso a sus recursos naturales. Para la Corte IDH, lo anterior se produce por el hecho de que las comunidades indígenas del Paraguay tienen un estrecho vínculo cultural con su tierra y, por ende, «el acceso a sus tierras ancestrales y al uso y disfrute de los recursos naturales que en ellas se encuentran están directamente vinculados con la obtención de alimento y el acceso a agua limpia $»^{20}$. Esta jurisprudencia se confirmó en el caso Sawhoyamaxa con Paraguay (2006) ${ }^{21}$ y fue enfatizada en el caso Xákmok Kásek con Paraguay (2010), ya que la Corte IDH consideró que «la ausencia de posibilidades de autoabastecimiento y auto-sostenibilidad de los miembros de la comunidad, de acuerdo a sus tradiciones ancestrales, los lleva a depender casi exclusivamente de las acciones estatales y verse obligados a vivir de una forma no solamente distinta a sus pautas culturales, sino en la miseria ${ }^{22}$. Como podemos apreciar, la Corte IDH no sólo caracteriza al pueblo indígena como un sujeto especial de protección, sino que vincula el derecho a la vida con el de propiedad para garantizar la supervivencia de la comunidad y su forma de vida, es decir, protege la diversidad cultural en sentido fuerte.

Otro aspecto en el que la jurisprudencia de la Corte IDH ha abordado aspectos culturales relacionados con el derecho a la vida en casos multiculturales es en aquellos relacionados con el entierro y trato de un cadáver conforme a la cultura indígena. En este punto los casos relevantes son: a) caso Bámaca Velásquez con Guatemala (2000); b) caso Moiwana con Surinam (2005); c) caso Masacres de Río Negro con Guatemala (2012).

La Corte IDH en el caso Bámaca Velásquez con Guatemala (2000), relativo a la desaparición forzada del miembro del Pueblo Indígena Maya Efraín Bámaca

19 Para un análisis completo de la jurisprudencia de la Corte IDH sobre el derecho a la vida, véase Ayala, C. y Rivero, M., "Artículo 4. Derecho a la Vida», en Steiner, CH. y Uribe, P. (eds.), Convención Americana sobre Derechos Humanos, KAS, Bogotá, 2014, pp. 112-130. Asimismo, véase Espejo, N. y Leiva, C., Digesto de jurisprudencia de la Corte Interamericana de derechos humanos, Thomson Reuters, Santiago, 2012, pp. 135-198.

${ }^{20}$ Cfr. SCrIDH (2005). Yakye Axa con Paraguay, párr. 167.

${ }^{21}$ Cfr. SCrIDH (2006). Sawhoyamaxa con Paraguay, párrs. 156-176.

${ }^{22}$ Cfr. SCrIDH (2010). Xákmok Kásek con Paraguay, párr. 214. 
Velásquez, consideró la existencia de un estrecho vínculo cultural para los miembros de dicho pueblo indígena y las honras fúnebres debido a que

esta Corte considera que el cuidado de los restos mortales de una persona es una forma de observancia del derecho a la dignidad humana. Asimismo, este Tribunal ha señalado que los restos mortales de una persona merecen ser tratados con respeto ante sus deudos, por la significación que tienen para éstos. El respeto a dichos restos, observado en todas las culturas, asume una significación muy especial en la cultura maya, etnia mam, a la cual pertenecía el señor Efraín Bámaca Velásquez. Ya la Corte ha reconocido la importancia de tener en cuenta determinados aspectos de las costumbres de los pueblos indígenas en América para los efectos de la aplicación de la Convención Americana sobre Derechos Humanos (Caso Mayagna (Sumo) Awas Tingni vs. Nicaragua). Como se ha reiterado en la audiencia pública sobre reparaciones en este caso, para la cultura maya, etnia mam las honras fúnebres aseguran la posibilidad de un reencuentro entre las generaciones de los vivos, la persona fallecida y los antepasados muertos. Así, el ciclo entre la vida y la muerte se cierra con esas ceremonias fúnebres, permitiendo «rendir respeto a Efraín, para tenerlo cerca y para devolverlo o llevarlo a convivir con los antepasados", así como para que las nuevas generaciones puedan compartir y aprender de lo que fue su vida, como es tradición en su cultura indígena ${ }^{23}$.

En el caso Moiwana con Surinam (2005) la Corte IDH realiza un razonamiento similar al del caso anterior, agregando que las afectaciones emocionales que sufrieron las víctimas de la comunidad indígena por el hecho de no poder honrar a sus muertos y enterrarlos según su cultura serían atentatorias no sólo con el derecho a la vida, sino también con el derecho a la integridad personal, consagrado en el artículo 5 de la Convención Americana de Derechos Humanos (CADH), por el sufrimiento que esto causaba en las víctimas (familiares) ${ }^{24}$.

Finalmente, en el caso Masacres de Río Negro con Guatemala (2012) la Corte IDH, junto con confirmar la jurisprudencia precitada vinculando las honras fúnebres con el derecho a la vida (artículo 4 de la CADH) y el derecho a la integridad personal (artículo 5 de la $\mathrm{CADH}$ ), también lo relaciona con el derecho a la libertad de conciencia y de religión, consagrado en el artículo 12 de la $\mathrm{CADH}^{25}$. Así, la Corte IDH señala que

... los miembros de la comunidad de Río Negro no pueden realizar sus rituales fúnebres por el hecho de que el Estado no ha localizado ni identificado a la mayor

${ }^{23}$ Cfr. SCrIDH (2002). Bámaca Velásquez con Guatemala, párr. 81.

${ }^{24}$ Cfr. SCrIDH (2005). Caso de la comunidad Moiwana con Surinam, párr. 100.

${ }_{25}$ Según Marco Huaco, si bien la Corte IDH había reconocido este derecho en la protección de las prácticas religiosas y el derecho a la identidad, hasta la fecha de su artículo esto no había sido aplicado en la parte resolutiva de las sentencias de la Corte IDH de manera explícita. Cfr. HuACO, M., "Artículo 12. Libertad de Conciencia y de Religión», en Steiner, CH. y Uribe, P. (eds.), Convención Americana sobre Derechos Humanos, KAS, Bogotá, 2014, p. 304. Asimismo, véase EsPejo y LeIVA, op. cit., p. 425. 
parte de los restos de personas supuestamente ejecutadas durante las masacres, y a que 17 personas se encuentran desaparecidas forzadamente. Pero, por otro lado, tampoco pueden realizar cualquier otro tipo de rituales pues los sitios sagrados a los cuales solían acudir se encuentran inundados a raíz de la construcción de la hidroeléctrica de Chixoy. Esta Corte ya ha señalado que «la relación especial de los pueblos indígenas con sus territorios ancestrales no estriba solamente en que constituyen su principal medio de subsistencia, sino un elemento integrante de su cosmovisión, religiosidad y, por ende, de su identidad o integridad cultural, el cual es un derecho fundamental y de naturaleza colectiva de las comunidades indígenas, que debe ser respetado en una sociedad multicultural, pluralista y democrática, como la de Guatemala ${ }^{26}$.

Con este último fallo la Corte IDH consolida una vanguardista jurisprudencia sobre el significado de los derechos de los pueblos indígenas en una sociedad multicultural en lo relacionado con sus derechos a la identidad cultural y religiosa. Como podemos apreciar, en este grupo de jurisprudencia para la Corte IDH el aspecto cultural es relevante no sólo para hacer una interpretación contextualizada y flexible de las normas de la CADH, sino también para conectar sus diferentes derechos (derecho a la vida, integridad personal y libertad de conciencia y de religión) ${ }^{27}$.

\section{II.II. Aspectos Culturales en las garantías JUdiciales}

La Corte IDH tiene una profusa jurisprudencia relacionada con el derecho a las garantías judiciales consagrado en el artículo 8 de la $\mathrm{CADH}^{28}$. En ese sentido, en materia multicultural indígena ha preceptuado la necesidad de que los miembros de los pueblos indígenas cuenten con un intérprete en sede jurisdiccional.

Así lo ha señalado en el caso Tiu Tojin con Guatemala (2008), relacionado con la desaparición forzada de Maria Tiu Tojin y su hija, quienes pertenecían al pueblo indígena maya. Para la Corte IDH, los familiares de la víctima tuvieron obstáculos para ejercer su derecho de acceso a la justicia debido a la falta de intérpretes para que la investigación de los hechos se hubiera realizado oportunamente. En ese sentido la Corte IDH señaló que

... para garantizar el acceso a la justicia de las víctimas -en tanto miembros del pueblo indígena Maya-y que la investigación de los hechos se realice con la debida

${ }^{26}$ Cfr. SCrIDH (2012). Caso Masacres de Río Negro con Guatemala, párr. 160.

27 Para una propuesta de interpretación de los derechos humanos en contextos multiculturales en el ámbito de los tribunales regionales de protección de los derechos humanos, véase GajARDo, J., Derechos humanos y multiculturalismo. Análisis comparado en la jurisprudencia de la Corte Interamericana y el Tribunal Europeo de Derechos Humanos, Thomson Reuters, Santiago, 2020.

${ }_{28} \mathrm{Al}$ respecto, véase IbÁÑez, J., "Artículo 8. Garantías Judiciales», en Steiner, CH. y Uribe, P. (eds.), Convención Americana sobre Derechos Humanos, KAS, Bogotá, 2014, pp. 207-254. Asimismo, véase Espejo y LeIva, op. cit., pp. 317-398. 
diligencia, sin obstáculos y sin discriminación, el Estado debe asegurar que aquellas puedan comprender y hacerse comprender en los procedimientos legales iniciados, facilitándoles intérpretes u otros medios eficaces para tal fin. Asimismo, el Estado deberá garantizar, en la medida de lo posible, que las víctimas del presente caso no tengan que hacer esfuerzos desmedidos o exagerados para acceder a los centros de administración de justicia encargados de la investigación del presente caso. Sin perjuicio de lo anterior, la Corte considera necesario ordenar al Estado el pago de una suma por concepto de gastos futuros, como una forma de garantizar que las víctimas puedan actuar en el proceso penal abierto ante la justicia ordinaria ${ }^{29}$.

Posteriormente, la Corte IDH resolvió en el caso Rosendo Cantú con México, en el que la víctima, que era miembro de la comunidad indígena me'paa y no hablaba español con fluidez, no pudo ejercer adecuadamente su derecho de acceso a la justicia cuando acudió a denunciar la violación sexual de la que había sido víctima por parte de militares mexicanos. En este caso, para la Corte IDH «no se proveyó a la señora Rosendo Cantú, quien al momento de los hechos no hablaba español con fluidez, de la asistencia de un intérprete, sino que debió ser asistida por su esposo, hecho que, a criterio de esta Corte no respeta su identidad cultural, y no resulta adecuado para asegurar la calidad del contenido de la declaración ni para proteger debidamente la confidencialidad de la denuncia. El Tribunal considera que resulta particularmente inapropiado que la señora Rosendo Cantú tuviera que recurrir a su marido para relatar los hechos de la violación sexual» ${ }^{30}$.

Este grupo de casos da cuenta de la importancia que tiene en la jurisprudencia de la Corte IDH la cultura indígena al momento de determinar el alcance de los derechos establecidos en la $\mathrm{CADH}$, que en este grupo de casos tenía relación con las garantías judiciales. Podemos apreciar que, para la Corte IDH, en sociedades multiculturales todos los derechos de la CADH se tienen que mirar bajo un prisma cultural y al momento de analizar un caso de tipo multicultural se deben tener en consideración las excepciones o especificaciones que se deben realizar en la interpretación de los derechos en juego, para lograr una plena efectividad de los derechos humanos.

${ }^{29}$ Cfr. SCrIDH (2008). Caso Tiu Tojin con Guatemala, párr. 100.

${ }^{30}$ Cfr. SCrIDH (2010). Caso Rosendo Cantú y otra con México, párr. 179. Comentando estos dos últimos casos, Oswaldo Ruiz y Gina Donoso señalan que no es clara la fuente normativa de la cual la Corte IDH ha derivado la obligación estatal según la cual para garantizar adecuadamente el acceso a la justicia se deba contar con un intérprete, ya que a su juicio la obligación contenida en el artículo 8 de la CADH no es fácil de desprender de dicho artículo. Al respecto, véase Ruiz, O. y Donoso, G., «Sección especial: Pueblos indígenas y la Corte Interamericana de Derechos Humanos. Fondo y reparaciones», en STEIner, CH. y URIBe, P. (eds.), Convención Americana sobre Derechos Humanos, KAS, Bogotá, 2014, p. 968. 
La jurisprudencia de la Corte IDH relativa a los derechos territoriales y la propiedad comunal indígena derivada del artículo 21 de la CADH es abundante y ha sido latamente revisada por diferentes autores ${ }^{31}$. Como en el presente trabajo me centro en los aspectos culturales de la jurisprudencia de la Corte IDH en el ámbito indígena, en este punto relevaré los fundamentos culturales que ha dado la Corte IDH para la protección de la propiedad comunitaria indígena.

Así, en un primer aspecto la Corte IDH ha fundamentado el derecho a la propiedad comunitaria por la «estrecha relación que los indígenas mantienen con la tierra», la que debe ser reconocida y comprendida como «la base fundamental de sus culturas, su vida espiritual, su integridad y su supervivencia económica. Para las comunidades indígenas la relación con la tierra no es meramente una cuestión de posesión y producción sino un elemento material y espiritual del que deben gozar plenamente, inclusive para preservar su legado cultural y transmitirlo a las generaciones futuras ${ }^{32}$.

Profundizando en el entendimiento del significado de cultura y su ligazón con la tierra y la propiedad comunitaria, la Corte IDH en el caso Yakye Axa señaló que

... la cultura de los miembros de las comunidades indígenas corresponde a una forma de vida particular de ser, ver y actuar en el mundo, constituido a partir de su estrecha relación con sus territorios tradicionales y los recursos que allí se encuentran, no sólo por ser estos su principal medio de subsistencia, sino además porque constituyen un elemento integrante de su cosmovisión, religiosidad y, por ende, de su identidad cultural ${ }^{33}$.

En el mismo sentido, para la Comisión Interamericana de Derechos Humanos $(\mathrm{CIDH})$ «la relación especial entre los pueblos indígenas y tribales y sus territorios significa que el uso y goce de la tierra y de sus recursos son componentes integrales de la supervivencia física y cultural de las comunidades indígenas y de la efectiva realización de sus derechos humanos en términos más generales» ${ }^{34}$.

Además, la $\mathrm{CIDH}$ ha señalado que dicha relación especial entre los pueblos indígenas y su territorio es fundamental para la integridad cultural de los pue-

${ }^{31} \mathrm{Al}$ respecto, entre otros, véase Russo, A. y Wences, I., «De los derechos de los "miembros de las comunidades" a los derechos de la "comunidad y sus miembros": la diversidad cultural y el reconocimiento de la propiedad colectiva de los pueblos indígenas en la Corte Interamericana de Derechos Humanos», en Santolaya, P., y Wences, I., La América de los Derechos, Centro de Estudios Políticos y Constitucionales, Madrid, 2016, pp. 281-326.

${ }^{32}$ Cfr. SCrIDH (2000). Caso Awas Tingi con Guatemala, párr. 149. Esto ha sido refrendado en los siguientes casos: a) caso Awas Tingi con Nicaragua (2000); b) caso Yakye Axa con Paraguay (2005); d) caso Sawhoyamaxa con Paraguay (2006); e) caso Xákmok Kásek con Paraguay (2010).

${ }_{33}$ Cfr. SCrIDH (2005). Caso Yakye Axa con Paraguay, párr. 135.

34 Cfr. CIDH (2010). Informe temático, pp. 21-22. 
blos indígenas, debido a «que los conceptos de familia y de religión se conectan íntimamente con el territorio tradicional, en donde los cementerios ancestrales, los lugares de significado e importancia religiosos y los patrones de parentesco se vinculan a la ocupación y uso de sus territorios físicos $»^{35}$. Así, para la CIDH la sociedad indígena se estructura en base a su relación profunda con la tierra, ya que la tierra constituye para los pueblos indígenas una condición de la seguridad individual y del enlace del grupo ${ }^{36}$.

Como podemos apreciar en la jurisprudencia sobre propiedad comunal indígena de la Corte IDH, la importancia cultural que tiene la relación de los pueblos indígenas con la tierra para la noción misma del significado de ser indígena y la constitución de sus comunidades no sólo es relevada por la Corte IDH al momento de interpretar el artículo 21 de la $\mathrm{CADH}$, sino que es la base para configurar un nuevo tipo de derecho humano a la propiedad en el caso de los pueblos indígenas, que tiene las características de ser un derecho de grupo y que se conecta con una serie de derechos protegidos en la CADH, tales como el derecho a la vida, la libertad de conciencia y religión y el derecho de protección a la familia.

La construcción teórica que realiza la Corte IDH en el caso del derecho a la propiedad comunal indígena amparado en el artículo 21 de la CADH y su fundamento en la importancia cultural que tiene la especial relación con la tierra en el caso de los pueblos indígenas da cuenta de la óptica con la que enfrenta los casos de tipo multicultual la Corte IDH, siendo esta la de una amplia protección del principio de integridad cultural. Además, en la resolución de este tipo de casos, podemos apreciar cómo la Corte IDH utiliza las herramientas prácticas que ha dejado el debate multicultural, tales como la inversión de la carga de la prueba, la interpretación contextualizada y la deferencia a la cultura indígena ${ }^{37}$.

\section{II.IV. Aspectos Culturales en El DERECHO DE PROTECCión A LA FAMilia y LA NIÑEZ}

El artículo 17 de la CADH consagra el derecho de protección a la familia, afirmando que esta es un elemento natural y fundamental de la sociedad y que debe ser protegida por el Estado. Tal como apunta Mary Beloff, el concepto de familia ha tenido un desarrollo en el derecho internacional de los derechos humanos, transitando desde concepciones tradicionales y restrictivas hacia nociones abiertas y plurales, adaptándose a las diversas circunstancias, contextos y realidades sociales ${ }^{38}$.

Lo anterior es especialmente significativo en sociedades multiculturales, siendo relevante que en la interpretación de «los múltiples sentidos de la institu-

35 Cfr. ibid., p. 22.

36 Idem.

37 Al respecto, véase Gajardo, J., op. cit., pp. 72-83.

38 Cfr. Beloff, M., "Artículo 17. Protección a la familia», en Steiner, CH. y Uribe, P. (eds.), Convención Americana sobre Derechos Humanos, KAS, Bogotá, 2014, p. 389. 
ción "familia" y asegurar su debida protección es fundamental tener en cuenta que la Corte IDH ha establecido que los tratados de derechos humanos son instrumentos vivos, cuya interpretación tiene que acompañar la evolución de los tiempos y las condiciones de vida actuales" ${ }^{39}$.

Esta diversidad del concepto y alcance de las «familias» en contextos multiculturales fue reconocida por la Corte IDH en el caso Chitay Nech y otros con Guatemala. En dicho caso, la Corte IDH amplió el concepto de «familia» y el de «convivencia familiar» en el contexto indígena, señalando que esta no se limita al núcleo familiar dado por el parentesco, sino que incluye a las distintas generaciones que la componen e incluso a la comunidad de la cual se forma parte ${ }^{40}$.

Para la Corte IDH el desplazamiento forzado de la familia Chitay fuera de su comunidad provocó una ruptura con su identidad cultural, afectando su vínculo con sus familiares, su idioma y su pasado ancestral, generando para el Estado responsabilidad internacional por vulneración al artículo 17 de la $\mathrm{CADH}^{41}$. Así, para la Corte IDH el deber de protección de la vida familiar implica acciones positivas de resguardo hacia todas las estructuras familiares, así como en una amplia y plural concepción de la familia ${ }^{42}$.

Por su parte, en el caso de los derechos de la niñez, el artículo 19 de la CADH señala que los niños tienen el derecho a las medidas de protección que se requieran por parte de su familia, de la sociedad y del Estado ${ }^{43}$. En ese sentido, cuando se trata de nińos de comunidades indígenas, para la Corte IDH los Estados tienen una obligación adicional, cuya fuente normativa se encuentra en el artículo 30 de la Convención de Derechos del Niño ${ }^{44}$, que dice relación con la promoción y protección del derecho de los niños indígenas a vivir de acuerdo con su propia cultura, religión e idioma ${ }^{45}$.

Así lo determinó la Corte IDH en el caso de la Comunidad Indígena Xákmok Kásek con Paraguay al señalar que

Con respecto a la identidad cultural de los niños nińas de comunidades indígenas, el Tribunal advierte que el artículo 30 de la Convención sobre los Derechos del

39 Idem. Asimismo, véase Espejo y Leiva, op. cit., pp. 477-480.

${ }^{40}$ Cfr. SCrIDH (2010). Caso Chitay Nech y otros con Guatemala, párr. 159. Asimismo, véase SCrIDH (2014). Caso Norín Catrimán y otros con Chile, párrs. 402-411.

${ }^{41}$ Cfr. ibid., párrs. 159-163.

${ }^{42}$ Cfr. Beloff, op. cit., p. 426.

43 Para un estudio amplio de los deberes del Estado en razón de este artículo de la $\mathrm{CADH}$, véase Beloff, M., "Artículo 19. Derechos del niño», en Steiner, CH. y Uribe, P. (eds.), Convención Americana sobre Derechos Humanos, KAS, Bogotá, 2014, p. 389. Asimismo, véase Espejo y LeIVA, op. cit., pp. 487-520.

${ }^{44}$ El artículo 30 de la Convención de Derechos del Niño señala: «En los Estados en que existan minorías étnicas, religiosas o lingüísticas o personas de origen indígena, no se negará a un nińo que pertenezca a tales minorías o que sea indígena el derecho que le corresponde, en común con los demás miembros de su grupo, a tener su propia vida cultural, a profesar y practicar su propia religión, o a emplear su propio idioma».

${ }^{45}$ Cfr. Ruiz y Donoso, op. cit., p. 994. 
Niño establece una obligación adicional y complementaria que dota de contenido al artículo 19 de la Convención Americana, y que consiste en la obligación de promover y proteger el derecho de los nińos indígenas a vivir de acuerdo con su propia cultura, su propia religión y su propio idioma ${ }^{46}$.

Lo anterior fue ratificado por la Corte IDH en los casos Chitay Nech y otros con Guatemala $(2010)^{47}$ y en el caso Masacres de Río Negro con Guatemala $(2012)^{48}$. En particular, la Corte IDH en el caso Masacres de Río Negro señala que

... esta Corte ha sostenido que el desarrollo del niño es un concepto holístico que abarca el desarrollo físico, mental, espiritual, moral, psicológico y social. Para el desarrollo pleno y armonioso de su personalidad, los niños indígenas, de acuerdo con su cosmovisión, preferiblemente requieren formarse y crecer dentro de su entorno natural y cultural, ya que poseen una identidad distintiva que los vincula con su tierra, cultura, religión, e idioma ${ }^{49}$.

Con los grupos de casos revisados previamente, podemos apreciar (nuevamente) que la Corte IDH realiza un interpretación de los derechos humanos sensible a los aspectos culturales y que busca la plena realización de los mismos realizando un escrutinio fuerte de la actividad estatal. Para la Corte IDH en los casos de tipo multicultural se debe tener en consideración el papel que juegan las especificidades culturales en la configuración y posterior aplicación de los derechos humanos consagrados en la CADH.

\section{II.v. Aspectos Culturales EN El DeReCho A LA Libertad De PENSAMiento y DE EXPRESIÓN}

Para la Corte IDH la libertad de pensamiento y de expresión son parte de la trilogía de libertades personales que constituyen el prerrequisito de los derechos de participación política y son fundamentales para posibilitar el sistema democrático $^{50}$. De esta forma, el artículo 13 de la CADH establece el derecho a la libertad de pensamiento y de expresión, en el que, según la Corte IDH, la expresión y difusión del pensamiento constituyen una dimensión del mismo ${ }^{51}$. Así, en sociedades

46 Cfr. SCrIDH (2010). Caso Comunidad Indígena Xákmok Kásek con Paraguay, párr. 261.

47 Véase SCrIDH (2010). Caso Chitay Nech y otros con Guatemala, párrs. 167-168.

48 Véase SCrIDH (2012). Caso Masacres de Río Negro con Guatemala, párrs. 142-150.

49 Cfr. SCrIDH (2012). Caso Masacres de Río Negro con Guatemala, párr. 144.

50 Al respecto, véase SCrIDH (2010). Caso Manuel Cepeda con Colombia, párrs. 168-179.

51 Para un estudio amplio del derecho a la libertad de pensamiento y expresión en el marco de la CADH, véase Bertoni, E. y Zelada, C., «Artículo 13. Libertad de pensamiento y de expresión", en Steiner, CH. y Uribe, P. (eds.), Convención Americana sobre Derechos Humanos, KAS, Bogotá, 2014, p. 389, pp. 320-342. Asimismo, véase Espejo y Leiva, op. cit., pp. 427-465. 
multiculturales de fuente indígena se podría catalogar esta dimensión como el derecho a usar la lengua propia ${ }^{52}$.

En ese sentido, la Corte IDH en el caso López Álvarez con Honduras (2006), en el que se denunciaba al director del Centro Penitenciario de prohibir a la población indígena (garífuna) del penal utilizar su idioma, señala que: «el artículo 13.1 consagra expresamente la libertad de difundir oralmente la información. La Corte considera que uno de los pilares de la libertad de expresión es precisamente el derecho a hablar, y que éste implica necesariamente el derecho de las personas a utilizar el idioma de su elección en la expresión de su pensamiento. La expresión y la difusión de pensamientos e ideas son indivisibles, de modo que una restricción de las posibilidades de divulgación representa directamente, y en la misma medida, un límite al derecho de expresarse libremente: ${ }^{53}$.

Para la Corte IDH, los Estados tienen la obligación de considerar las diferencias entre la población indígena y la mayoritaria, con el objeto de adecuar y proteger culturalmente a la indígena, tomando en consideración que el idioma de los mismos es uno de los principales elementos de su cultura e identidad, ya que garantiza la expresión, difusión y transmisión de su cultura. Así, cualquier interferencia o restricción de la misma afecta gravemente el derecho a la libertad de pensamiento y expresión consagrado en el artículo 13 de la $\mathrm{CADH}$ y que en contextos multiculturales se manifiesta en el derecho a usar la lengua propia ${ }^{54}$.

En este caso, la Corte IDH construye (a partir de la cultura) una protección externa (en el sentido de Kymlicka) ${ }^{55}$ a favor de la supervivencia cultural de los pueblos indígenas y la protección de su integridad cultural. Las protecciones externas a los grupos culturales es una de las vías que han planteado los teóricos del liberalismo multicultural para establecer derechos diferenciados a los grupos étnicos y culturales dada la relevancia que tendrían estos para la autonomía de sus miembros ${ }^{56}$. Recogiendo estos presupuestos teóricos, la Corte IDH construye una garantía de este tipo realizando una interpretación contextualizada y flexible del derecho a la libertad de pensamiento y expresión consagrado en el artículo 13 de la $\mathrm{CADH}$.

${ }^{2}$ Cfr. Ruiz y Donoso, op. cit., p. 970.

33 Cfr. SCrIDH (2006). Caso López Álvarez con Honduras, párr. 165.

${ }^{4}$ Cfr. SCrIDH (2006). Caso López Álvarez con Honduras, párrs. 171-173.

55 Véase Kyмlicka, W., Ciudadanía multicultural, Paidós, Barcelona, 1996.

56 Idem. 
La Corte IDH ha desarrollado ampliamente las modalidades de reparación, siendo uno de los aspectos novedosos de la jurisprudencia de la misma ${ }^{57}$. En ese sentido la cultura indígena ha sido fundamental en la jurisprudencia de la Corte IDH tanto para la determinación de los beneficiarios de las reparaciones como para la evaluación del daño inmaterial.

En cuanto al rol que ha jugado la cultura indígena para la determinación de los beneficiarios de las reparaciones, la Corte IDH en el caso Aloeboetoe con Surinam (1993) no aplicó las normas del derecho civil nacional para ello, sino que reconoció las costumbres del pueblo indígena. Así, para la determinación de los herederos de las víctimas interpretó, según la cultura y costumbre indígena, los términos de «hijos», "cónyuge» $\mathrm{y}$ «ascendientes»" ${ }^{58}$.

Asimismo, la cultura indígena ha jugado un rol relevante en la determinación del daño inmaterial. Así, en el caso Aloeboetoe con Surinam la Corte IDH amplió el concepto de víctima para la determinación del daño, ya que consideró que los miembros de la comunidad indígena constituían una familia en sentido amplio, por lo que el daño que se le causaba a uno se les producía a todos, ordenando el pago de una indemnización por cada una de las víctimas ${ }^{59}$.

57 Al respecto, véase NASH (2009), pp. 9-94. Para un estudio sobre las formas de reparación y peculiaridades que deben tener estas cuando se trata de víctimas indígenas, véase Ruiz y Donoso, op. cit., pp. 998-1024.

${ }^{58}$ Cfr. SCrIDH (2006). Caso Aloeboetoe y otros con Surinam, párrs. 60-66. Sin embargo, «[...] al referirse a los ascendientes, la Corte advirtió que no haría ninguna distinción de sexos, aun cuando ello sea contrario a la costumbre. Por ende, tomó como beneficiarios de las reparaciones a las esposas de los cimarrones fallecidos, a los hijos de éstos con cada una de sus esposas, y al padre y madre de los fallecidos, sin hacer distinciones basadas en el género. El Tribunal básicamente dio prioridad al derecho individual por sobre el derecho colectivo, sin explicar por qué la cultura de la tribu en este punto violentaba algún derecho humano y sin hacer algún juicio de ponderación que explique el motivo de la preferencia de un derecho (individual) por sobre otro (colectivo). Es de notar que los familiares de las víctimas o sus representantes legales no solicitaron a la Corte que desconociera la cultura de su grupo. El Tribunal, sin petición de por medio, decidió dar prevalencia al enfoque de género en lugar del cultural. Esto puede dar lugar a muchos debates, sin embargo, un argumento interesante es este contexto es el de Culberstone y Pouligny, quienes demuestran que los grupos locales retornan a la tradición para resolver conflictos, pero también reconocen que las innovaciones parten de la realidad de cada cultura, y que tomando y ajustando ideas desde el exterior y reconfigurando viejos conceptos a nuevas experiencias se planifican y ajustan las estrategias locales». $C f$ r. Ruiz y Donoso, op. cit., p. 1001.

59 Cfr. SCrIDH (2006). Caso Aloeboetoe y otros con Surinam, párr. 83. Asimismo, véase SCrIDH (2000). Caso Awas Tingi con Nicaragua, párr. 83; SCrIDH (2004). Caso Plan de Sánchez con Guatemala, párrs. 80-83. 


\section{CONCLUSIONES}

Como hemos podido apreciar, en los casos de tipo multicultural de fuente indígena la Corte IDH incorpora de manera fuerte en la interpretación de las normas de la $\mathrm{CADH}$ los aspectos culturales, construyendo entendimientos específicos de los derechos convencionales para dichos casos y evaluando la actividad estatal bajo dicho prisma, es decir, bajo una óptica de tipo multicultural. Que la Corte IDH incorpore de forma fuerte los derechos culturales de los pueblos indígenas significa que establece un deber estricto de los Estados en la protección de las diferentes expresiones culturales de los pueblos indígenas, siendo estas fundamentales para una adecuada protección de los derechos a través de los que se expresan.

En este sentido, de la revisión jurisprudencial se puede constatar que para la Corte IDH la cultura de los pueblos indígenas tiene un rol importante en la determinación del contenido: del derecho a la vida; del debido proceso; del derecho a la propiedad y su configuración como el de propiedad comunal indígena; en el derecho de protección a la familia; y en el derecho a la libertad de expresión. De esta forma, cuando un miembro de un pueblo indígena o un pueblo indígena como tal recurre ante el Sistema Interamericano de Protección de los Derechos Humanos, los órganos del sistema evalúan la actividad estatal y su conformidad a la $\mathrm{CADH}$ incorporando en la interpretación de los derechos en cuestión la cultura indígena y estableciendo un deber estricto de protección de la integridad cultural por parte de los Estados.

Además, en la jurisprudencia analizada se puede evidenciar que para la Corte IDH los pueblos indígenas son un grupo vulnerable y, por ende, la protección que les debe brindar se encuentra reforzada por ese hecho. Debido a lo anterior, los derechos culturales de los pueblos indígenas forman parte de la especial protección que se les otorga y sus especifidades culturales son contextualizadas en el marco de culturas hegemónicas que los desatienden, invisibilizan o, derechamente, los discriminan.

¿Cuál sería el límite de la protección a los derechos culturales de los pueblos indígenas? Por ahora, la protección que les ha brindado la Corte IDH da cuenta de un conjunto de interpretaciones de los derechos de la CADH dentro del marco de entendimientos deferentes con las prácticas culturales de los pueblos indígenas y con prácticas que vienen a complementar los derechos de la $\mathrm{CADH}$ que hemos revisado. Sin embargo, la Corte IDH no ha tenido que resolver casos en los que las prácticas culturales de los pueblos indígenas puedan entrar en colisión con el núcleo de alguno de los derechos humanos de la $\mathrm{CADH}$ o que una deferencia hacia ellos pueda implicar la vulneración de derechos de terceros. En ese sentido, en términos generales podríamos señalar que la protección que ha otorgado la Corte IDH viene a complementar y especificar los derechos de la $\mathrm{CADH}$, aunque será interesante apreciar en el futuro posibles límites a la protección de los derechos culturales de los pueblos indígenas cuando estos afecten el núcleo de los derechos de la $\mathrm{CADH}$ o su protección pueda implicar la vulneración de los derechos humanos de terceros.

Así, podemos concluir anotando que la Corte IDH ha dado una amplia protección a las personas indígenas y sus comunidades, otorgándole a la cultura indígena un papel relevante al momento de resolver los casos que han sido sometidos 
a su conocimiento y en ámbitos culturales tan variados como aquellos que tienen impacto en el contenido del derecho a la vida; del derecho a las garantías judiciales; del derecho a la propiedad comunal; del derecho a la familia y de los derechos de la niñez indígena; del derecho a libertad de pensamiento y de expresión; y en cuanto a las medidas de reparación.

ReCiBIDO: septiembre de 2020; ACEPTADO: diciembre de 2020 


\title{
EL DERECHO AL MEDIO AMBIENTE SANO COMO UN DERECHO AUTÓNOMO EN EL SISTEMA INTERAMERICANO DE DERECHOS HUMANOS*
}

\author{
Digno José Montalván Zambrano** \\ Universidad Carlos III de Madrid
}

\section{RESUMEN}

La Opinión Consultiva de la Corte Interamericana de Derechos Humanos N. ${ }^{\circ}$ OC-23/17, de 15 de noviembre de 2017, sobre medio ambiente y derechos humanos y la sentencia del caso Lhaka Honhat vs. Argentina, de 6 de febrero de 2020, desarrollan el contenido del derecho al medio ambiente sano desde un enfoque que podríamos advertir como ecocéntrico. Este derecho, como derecho autónomo, protege a la naturaleza ya no solo por su utilidad para el ser humano (visión antropocéntrica-instrumental), sino por su importancia para los demás organismos vivos con quienes se comparte el planeta (visión ecocéntrica-no instrumental). El presente trabajo analiza este nuevo derecho dando cuenta tanto de los posibles presupuestos filosóficos jurídicos que lo informan como de los posibles cambios que este nuevo enfoque puede traer en el Sistema Interamericano de Derechos Humanos.

PALABRAS ClAVE: derecho al medio ambiente sano, derechos de la naturaleza, ecocentrismo, antropocentrismo, Corte Interamericana de Derechos Humanos.

\section{THE RIGHT TO A HEALTHY ENVIRONMENT AS AN AUTONOMOUS RIGHT IN THE INTER-AMERICAN HUMAN RIGHTS SYSTEM}

\section{Abstract}

The Advisory Opinion of the Inter-American Court of Human Rights No. OC-23/17, of 15 November 2017, on "Environment and Human Rights" and the ruling in the case Lhaka Honhat V. Argentina of 6 February 2020, develops the content of the right to a healthy environment from an approach that we could see as ecocentric. This right, as an autonomous right, protects nature not only because of its usefulness for human beings (anthropocentric-instrumental vision), but also because of its importance for other living organisms with which the planet is shared (biocentric-not instrumental vision). This paper analyzes this new right, giving an account of the possible legal philosophical presuppositions that inform it, as well as the possible changes that this new approach may bring to the Inter-American System of Human Rights.

KEYwORDs: right to a healthy environment, rights of nature, ecocentrism, anthropocentrism, Inter-American Court of Human Rights. 


\section{A MODO DE INTRODUCCIÓN: DE LA INTENSIFICACIÓN \\ DE LA MINERÍA A LOS DERECHOS DE LA NATURALEZA, LA EVOLUCIÓN DE LA CUESTIÓN AMBIENTAL EN LA NORMATIVA Y JURISPRUDENCIA INTERAMERICANA}

El 30 de abril de 1948 se aprobó el texto original de la Carta de la Organización de Estados Americanos (en adelante, Carta de la OEA), en cuyo artículo 26 los Estados se comprometían a cooperar entre sí a fin de, entre otros, «intensificar su agricultura y su minería». 19 años más tarde, el 27 de febrero de 1967, el «Protocolo de Buenos Aires» reformó dicho artículo 26, eliminando el objetivo de «intensificación de la minería» e incluyendo el "desarrollo integral» como nueva meta y concepto dentro de la Carta ${ }^{1}$. En esta primera etapa el desarrollo integral proponía un modelo basado en la expansión del uso de la tierra e industrialización acelerada que, con rasgos sociales, pero no ecológicos, buscaba lo que la misma Carta define como "desarrollo sostenido» (actual art. 34 de la Carta).

En noviembre de 1969 se suscribe la Convención Americana sobre Derechos Humanos y en esta tampoco se contempla ninguna disposición relativa al medio ambiente. Tendrían que pasar 19 años, esto es, hasta la aprobación en 1988 del Protocolo Adicional a la Convención Americana sobre Derechos Humanos en materia de derechos económicos, sociales y culturales (Protocolo de San Salvador), para que la preocupación por el medio ambiente aparezca en la normativa interamericana de la mano del derecho humano a un medio ambiente sano (artículo 11 del Protocolo).

Cuatro años más tarde, en 1992, se aprueba en Rio de Janeiro la Declaración de Naciones Unidas sobre Medio Ambiente y el Desarrollo y, con ella, se introduce el concepto de "desarrollo sostenible» en la normativa universal. Con este antecedente, en 1993 se reforma Carta de la OEA y se crea el Consejo Interamericano para el Desarrollo Integral (CEDI) (artículos 93 a 98 de la Carta), al cual se le otorga la responsabilidad de promover y coordinar el desarrollo de programas relativos a, entre otros, el «desarrollo económico y social, incluyendo [...] el medio ambiente» (art. 95).

Tres años después, el 8 de diciembre de 1996, los jefes de Estado y de Gobierno de las Américas aprueban la Declaración de Principios sobre Desarrollo Sostenible y, seis meses más tarde, el 5 de junio de 1997, la Asamblea General de

* La realización de este trabajo ha tenido lugar en el marco del proyecto de investigación "Jueces en Democracia. La filosofía política de la Corte Interamericana de Derechos Humanos» (DER2016- 79805-P, AEI/FEDER, UE) y del proyecto «Teorías de la justicia y derecho global de los derechos humanos» (PID2019 107172RB-I00), ambos financiados por el Ministerio de Ciencia e Innovación de España y adscritos al Grupo de Investigación sobre el Derecho y la Justicia de la UC3M.

** Investigador predoctoral (FPI-MINECO) y miembro del grupo de investigación sobre el derecho y la justicia (GIDyJ) de la Universidad Carlos III de Madrid. Trabajó como abogado especialista en derechos sociales de la dirección nacional de la Defensoría del Pueblo de Ecuador; actualmente es cocoordinador del taller sobre el derecho y la justicia de la Universidad Carlos III de Madrid y editor de Eunomia, Revista en cultura de la legalidad.

${ }^{1}$ Actuales artículos 30 al 52 de la Carta de la OEA. 
la OEA aprueba el Plan Estratégico de Cooperación Solidaria 1997-2001, el cual contemplaba como uno de sus objetivos la conservación del medio ambiente y el «desarrollo sostenible». Con ello, casi cincuenta años después de la aprobación de la Carta de la OEA, se supera el modelo extractivo de "desarrollo sostenido" y se da paso al modelo de "desarrollo sostenible». Este se consolida con la aprobación de la Carta Democrática Interamericana el 11 de septiembre de 2001, en cuyo artículo 15 se establece la obligación de implementar "políticas y estrategias de protección del medio ambiente [...] para lograr un "desarrollo sostenible" en beneficio de las futuras generaciones». Producto de lo anterior, el "desarrollo integral» deja su inicial vocación extractiva vinculada al enfoque del «desarrollo sostenido» y pasa a ser definido dentro del sistema interamericano como «el nombre general dado a una serie de políticas que trabajan conjuntamente para fomentar el desarrollo sostenible» ${ }^{2}$.

Este cambio tendría un gran impacto en el sistema interamericano de protección de derechos humanos. Así, ese mismo año, el 31 de agosto de 2001, la Corte Interamericana de Derechos Humanos (en adelante, Corte IDH) emite la sentencia del caso de la Comunidad Mayagna (Sumo) Awas Tingni vs. Nicaragua, la primera en referirse a la relación ser humano-naturaleza en el marco de los derechos humanos ${ }^{3}$. Desde ese momento, la Corte comienza a desarrollar una prolífera jurisprudencia sobre la importancia de la protección del ambiente para la realización de los derechos humanos, haciendo uso, durante 16 años, de la protección por conexión ${ }^{4}$. Esto es, sin declarar directamente vulnerado el derecho al ambiente sano consagrado en el artículo 11 del Protocolo de San Salvador, sino dando cuenta de cómo las afectaciones ambientales creaban escenarios de vulneración de derechos civiles y políticos. Bajo esta forma de protección, siguiendo la propuesta del «desarrollo sostenible», la naturaleza importa únicamente en tanto que instrumento indispensable para la vida humana, es decir, no se protege a la naturaleza toda, sino únicamente a aquellos aspectos ambientales esenciales para el cumplimiento de los derechos humanos.

Finalmente, el 15 de noviembre de 2017, en la Opinión Consultiva 23/17 sobre medio ambiente y derechos humanos (en adelante OC 23/17), la Corte IDH da un giro respecto de la protección por conexión e instrumental antes expuesta y

2 Así define actualmente desarrollo integral la Secretaría Ejecutiva para el Desarrollo Integral de la OEA (SEDI). Al respecto véase http://www.oas.org/es/temas/desarrollo_integral.asp (fecha de última consulta: 17/09/2020).

${ }^{3}$ Corte Interamericana de Derechos Humanos, Sentencia del caso de la Comunidad Mayagna (Sumo) Awas Tingni vs. Nicaragua de 31 de agosto de 2001, párr. 149.

${ }^{4}$ Casos: Comunidad indígena Yakye Axa vs. Paraguay, 2005, párr. 163; caso del Pueblo Saramaka vs. Surinam, 2007, párr. 126; caso Kawas Fernández vs. Honduras, 2009, párr. 148; caso de la comunidad indígena Xákmok Kásek vs. Paraguay, 2010, párr. 169-170; caso Pueblo Indígena Kichwa de Sarayaku vs. Ecuador, 2012, párr. 147; caso de las comunidades afrodescendientes desplazadas de la Cuenca del Río Cacarica (Operación Génesis) vs. Colombia, 2013, párr. 354; caso comunidad Garífuna de punta piedra y sus miembros vs. Honduras, 2015, párr. 125-129; caso pueblos Kaliña y Lokono vs. Surinam, 2015, párr. 181. 
consagra lo que denomina «el derecho al medio ambiente sano como derecho autónomo». Este nuevo derecho, tal como lo expone la misma Corte, "protege los componentes del medio ambiente, tales como bosques, ríos, mares y otros, como intereses jurídicos en sí mismos, aún en ausencia de certeza o evidencia sobre el riesgo a las personas individuales" ${ }^{5}$.

Más de dos años después, en su más reciente sentencia en la materia, el caso comunidades indígenas miembros de la Asociación Lhaka Honhat (nuestra tierra) vs. Argentina, de 6 de febrero de 2020, la Corte declara, por primera vez en un caso contencioso, la vulneración del derecho al medio ambiente sano como derecho autónomo, reiterando que dicho derecho «trata de proteger la naturaleza», no solo por su «utilidad» o «efectos» respecto de los seres humanos, «sino por su importancia para los demás organismos vivos con quienes se comparte el planeta ${ }^{6}$. De esta forma, el interés por la preservación de la naturaleza ya no gira exclusivamente en torno al ser humano, sino, también, a la naturaleza misma. Surge así una mirada «ecocéntrica» de la relación humano-naturaleza dentro del sistema interamericano de derechos humanos, la cual, tal como ha sido incorporada dentro del discurso jurídico, desemboca en la idea de los «derechos de la naturaleza».

Siguiendo esta línea evolutiva, el presente artículo presenta las razones que nos permiten afirmar que "el derecho al medio ambiente sano como derecho autónomo" se separa de la tradicional vertiente antropocéntrica bajo la cual se ha construido el discurso del derecho al "ambiente sano». Con este objetivo, en primer lugar, se efectúa una breve aproximación sobre las discusiones filosófico-políticas que, en nuestra consideración, inspiraron e inspiran las apuestas por el derecho al desarrollo (en su primera formulación de desarrollo sostenido no ambientalmente comprometido), el derecho al medio ambiente (vinculado a la idea antropocéntrica de desarrollo sostenible) o los derechos de la naturaleza (de matriz ecocéntrica); en segundo lugar, se explica el contenido que ha dado la jurisprudencia interamericana a la tradicional versión antropocéntrica del derecho a un medio ambiente sano; en tercer lugar, se presenta el contenido de la vertiente que denominamos ecocéntrica y cercana a los derechos de la naturaleza, esto es, del derecho a un medio ambiente sano como derecho autónomo, y, finalmente, se ofrecen conclusiones respecto de las oportunidades y desafíos de esta nueva visión.

5 Corte Interamericana de Derechos Humanos, Opinión Consultiva OC-23/17, medio ambiente y derechos humanos, de 15 de noviembre de 2017, párr. 62.

${ }^{6}$ Corte Interamericana de Derechos Humanos, Sentencia del caso comunidades indígenas miembros de la Asociación Lhaka Honhat (nuestra tierra) vs. Argentina, de 6 de febrero de 2020, párr. 203. 


\section{ANTROPOCENTRISMO Y ECOCENTRISMO: UNA APROXIMACIÓN CONCEPTUAL ${ }^{7}$}

La evolución normativa y jurisprudencial expuesta en el apartado anterior puede ser explicada a partir de su puesta en común con las distintas posturas filosóficas que han guiado nuestros debates sobre la relación humano-naturaleza. Vista de esta forma, dicha evolución sería prueba del largo camino recorrido desde que el Cogito cartesiano, base del racionalismo occidental, consagrara el imperio de la razón sobre la materia y, con ello, la división humano-naturaleza ${ }^{8}$. De esta división surgió una visión mecanicista de la vida física que, en términos morales, desembocó en lo que el juez de la Corte IDH Eugenio Raúl Zaffaroni llama el "despropósito de René Descartes»", esto es, la concepción de los animales como máquinas ${ }^{10}$, como simples cosas desposeídas de toda alma sobre las que no existe obligación alguna.

El tipo de relacionalidad cartesiana forjó el sistema de valores que está en la base de nuestra cultura ${ }^{11}$, una doctrina en la que el ser humano es el "centro» $y$ único destinatario de las preocupaciones morales, mientras que la naturaleza, en su consideración de "cosa», importa únicamente de manera indirecta, es decir, en tanto que recurso necesario para nutrir nuestros procesos productivos e idea de desarrollo. La propuesta del «desarrollo sostenido» que dominó la primera etapa de la normativa interamericana responde a esta aproximación, esto es, un modelo de desarrollo sin ninguna preocupación ambiental.

El carácter insostenible de esta aproximación generó en la filosofía y, más adelante, en el derecho respuestas diversas sobre nuestro entendimiento y relación con la naturaleza. Estas respuestas, a grandes rasgos, se pueden clasificar en tres grupos: 1) las respuestas antropocéntricas de inspiración kantiana sobre los deberes indirectos hacia la naturaleza. De estas se desprenden los enfoques normativos «ambientalistas» que, en el derecho, han tomado el nombre de «derecho al ambiente sano»; 2) las respuestas biocéntricas inspiradas en el utilitarismo de Jeremy Bentham, que, en el derecho, han dado forma a la corriente de los derechos de los animales, y 3 ) las respuestas ecocéntricas formuladas en Occidente desde el ecologismo profundo (Deep ecology) -cuyas raíces se han rastreado hasta la idea de autorrealización de Spino-

7 No es el objetivo de este trabajo abordar a profundidad el debate teórico sobre estos dos conceptos. Para un estudio más detallado de los términos antropocentrismo, biocentrismo, ecocentrismo y sus traducciones legales, se puede consultar Montalván Zambrano, D., "Justicia ecológica = Ecological justice», Eunomí. . Revista en Cultura de la Legalidad, 18, 2020, pp. 179-198. https:// doi.org/10.20318/eunomia.2020.5272.

${ }^{8}$ Capra, F., El punto crucial, Editorial Troquel, Buenos Aires, 1992, p. 30.

9 Zaffaroni, E., La Pachamama y el humano, Ediciones Madres de Plaza de Mayo, Ciudad Autónoma de Buenos Aires, 2011, pp. 34-35.

${ }^{10}$ Descartes, R., Discurso del método; Meditaciones metafísicas, Tecnos, Madrid, 2002 [1637], p. 114.

${ }^{11}$ Capra, F., El punto crucial, Editorial Troquel, Buenos Aires, 1992, p. 27 y ss. 
za- ${ }^{12}$, pero que, además, han emergido de la revitalización de otras aproximaciones sobre el Ser históricamente relegadas, tales como el $a t m a n^{13}$ del pensamiento oriental o la ética de la Pachamama (madre tierra) del pensamiento andino ${ }^{14}$. Estas respuestas ecocéntricas han dado paso a una nueva corriente en el campo jurídico, los derechos de la naturaleza.

La segunda de estas respuestas, esta es, la corriente biocéntrica de los derechos de los animales, aunque plausible como propuesta normativa independiente, es, en nuestra opinión, incompatible con el discurso de los derechos humanos. Dado que el locus central de los derechos humanos es, inevitablemente, el ser humano, las dos únicas formas de incorporar al ambiente dentro de este discurso, en nuestra consideración, serían 1) plantear una redefinición de «lo humano», esto es, de aquello que nos constituye y que, por tanto, dentro de los derechos humanos debe ser protegido, o 2) dar cuenta de por qué es importante para el cumplimiento de los fines humanos preservar ciertos elementos ambientales.

El discurso de los derechos de los animales prescinde por completo de los dos objetivos antes expuestos. Así, no pretende dar cuenta de que el mundo no humano es parte constitutiva del ser humano ni de que le es funcionalmente relevante; por el contrario, desarrolla su argumentación en la vertiente inversa, esto es, «humanizando» a los animales. Pretende dar cuenta de que la separación de los animales sensibles de la comunidad moral es un prejuicio irracional basado en el «especismo»" ${ }^{15}$. Peter Singer, uno de los autores más relevantes de esta corriente, siguiendo la propuesta utilitarista de Jeremy Bentham ${ }^{16}$, considera que dicho especismo estaría en excluir del círculo moral a otras especies que, «al igual que nosotros», poseen la capacidad de sentir. El «nosotros antropocéntrico» es el parámetro de referencia, por lo que la menor o mayor relevancia moral de esas otras especies será directamente proporcional a su similitud con el ser humano. En esta misma línea, más recientemente, Martha Nussbaum ha ofrecido argumentos a favor de los derechos de los animales desde su propuesta del enfoque de las capacidades ${ }^{17}$, que,

12 DE Jonge, E., Spinoza and Deep Ecology. Challenging Traditional Approaches to Environmentalism, Routledge, Abingdon, 2004.

13 DE Jonge, E., op. cit, 2004, pp. 37-40.

${ }_{14}$ Zaffaroni, E., op. cit, 2011, pp. 117-123.

15 Singer, P., Liberación animal, Trotta, Madrid, 1999, p. 42.

${ }^{16}$ Este autor, con su búsqueda de la mayor felicidad para todos y, por tanto, inclinado a evitar el dolor en los seres sensibles, reconoció que los animales, "seres sensibles que han sido degradados a la clase de cosas por la insensibilidad de los antiguos juristas», son, en realidad, merecedores de respeto y del reconocimiento de sus derechos: Bentham, J., Introduction to the Principles of Morals and Legislation, The Clarendon Press, Oxford, 1879, p. 310. Traducción propia.

${ }_{17} \mathrm{Al}$ respecto, la autora establece: «Al permitir reconocer una amplia variedad de tipos de dignidad animal (y de las correspondientes necesidades para su florecimiento), y al dedicar atención a la diversidad de actividades y de objetivos de criaturas de múltiples clases, el mencionado enfoque es capaz de producir normas de justicia "interespecies" que, aun siendo sutiles, resultan a la vez exigentes e implican derechos fundamentales para criaturas diversas». Nussbaum, M., Las fronteras de la justicia: Consideraciones sobre la exclusión, Paidós, España, 2007, p. 323. 
con una jerarquía de especies fundamentada en el sensocentrismo, parece caer en el mismo argumento utilitarista ${ }^{18}$.

De este modo, al perseguir el discurso de los derechos de los animales un telos distinto al de los derechos humanos, y al no existir en el marco biocéntrico una propuesta dirigida a unir o establecer conexiones (más allá de analogías antropocéntricas) entre el mundo humano y el mundo animal, consideramos que no hay intervención posible de este enfoque dentro del marco de los derechos humanos. Así lo ha demostrado, por ejemplo, la Corte Europea de Derechos Humanos, al entender que el bienestar animal no es, en sí mismo, un bien a proteger dentro de los derechos humanos ${ }^{19}$.

Aclarado lo anterior, pasaré ahora a referirme a las dos respuestas que, en nuestra consideración, sí pueden ser trasladadas al discurso de los derechos humanos: las antropocéntricas y las ecocéntricas. En primer lugar, el antropocentrismo es la doctrina por la cual el ser humano es la sede y medida de todo valor ${ }^{20} \mathrm{o}$, más concretamente, «el error de dar una consideración exclusiva o arbitrariamente preferente a los intereses humanos frente a los intereses de otros seres ${ }^{21}$. Así, en su modelo perfecto, el antropocentrismo «otorga todos los derechos al hombre y ninguno a la naturaleza $»^{22}$. Es uno de los fundamentos más importantes de la idea moderna de derechos humanos y, con ello, un punto de partida insoslayable, incluso cuando hablamos del derecho humano al medio ambiente sano ${ }^{23}$, cuyo origen podemos rastrear, precisamente, hasta el antropocentrismo kantiano.

Para Kant, la razón, es decir, la capacidad del ser humano para proponerse fines a su arbitrio, es aquello que le hace merecedor de un fin en sí mismo y, por ende, de dignidad. De estas características desprende una conclusión fundamental dentro de sus reflexiones teleológicas sobre la relación ser humano-naturaleza: el posicionamiento del ser humano como el fin último del reino de los fines o, en sus palabras, «el fin en relación al cual todas las demás cosas de la naturaleza constituyen un sistema de fines ${ }^{24}$. El planteamiento ético que surge de lo anterior es la

${ }_{18}$ Nussbaum, M., op. cit, p. 347.

19 Al respecto se puede consultar Sparks, T., «Protection of Animals Through Human Rights: The Case-Law of the European Court of Human Rights», en Peters A. (eds.), Studies in Global Animal Law. Beiträge zum ausländischen öffentlichen Recht und Völkerrecht (Veröffentlichungen des Max-Planck-Instituts für ausländisches öffentliches Recht und Völkerrecht), vol. 290, Springer, Berlin, 2020. https://doi.org/10.1007/978-3-662-60756-5_13.

${ }_{20}$ Riechmann, J., Un mundo vulnerable: Ensayos sobre ecología, ética y tecnociencia, Catarata, Madrid, 2000, p. 37.

${ }^{21}$ Hayward, T., «Anthropocentrism: A misunderstood Problem», Environmental Values 6, n. ${ }^{\circ}$ 1, p. 51 (traducción propia).

${ }^{22}$ Ferry, L., El Nuevo orden ecológico. El árbol, el animal y el hombre, Tusquets Editores, Barcelona, 1994, P. 61.

${ }^{23}$ Woods, K., «Environmental Human Rights», en R. Holifield, J., Chakraborty y G. Walker (eds.), The Routledge Handbook of Environmental Justice (pp. 149-159), Routledge, Abingdon, 2018, p. 151.

${ }_{24}$ Kant, I., Critica del juicio. Seguida de las observaciones sobre el sentimiento de lo bello y lo sublime (A. García Moreno \& J. Rubira, Trads.), Librería de Iravedra, Madrid, 1876 [1790], p. 124. 
consideración de los animales, el reino vegetal y el reino mineral como cosas a disposición del ser humano ${ }^{25}$. Así, al preguntarse Kant ¿para qué existe el reino mineral, vegetal y animal?, su respuesta es contundente: «Para el hombre, para los diversos usos que su inteligencia le muestra que debe hacer de todos estos seres ${ }^{26}$.

Sin embargo, a diferencia de Descartes, la superior jerarquía que otorga el planteamiento kantiano al ser humano en el reino de los fines no le lleva concluir un uso indiscriminado de aquel otro fin «inferior» conformado por lo orgánico, pues, para Kant, existen deberes para con la naturaleza que se derivan de la propia dignidad humana, es decir, plantea obligaciones humanas para con la naturaleza fundamentadas en su importancia para el cumplimiento de los fines humanos. En otras palabras, propone una protección indirecta/instrumental de tipo antropocéntrico, por la cual los deberes hacia los animales y otros seres nacen de los deberes para con la humanidad ${ }^{27}$.

La propuesta de Kant resulta coherente si tenemos en cuenta que dentro de las perspectivas procedimentales que siguen la tradición del contrato social las preguntas sobre quién formula los principios y para quién se formulan los principios tienen necesaria y estructuralmente la misma respuesta. Las partes que crean el contrato social formulan principios por los que esas mismas personas se comprometen a vivir juntas. En este marco, al considerar Kant que los animales carecen de conciencia propia ${ }^{28} \mathrm{y}$, por tanto, de la capacidad de reciprocidad moral, les niega de forma rotunda la posibilidad de que puedan tener dignidad o valor intrínseco. En este marco, tal como establece Nussbaum, los animales no pueden ser sujetos primarios de justicia porque no pueden formular contratos, haciendo que su valor sea solo derivado e instrumental ${ }^{29}$. Esto ubica al planteamiento kantiano como el precursor del «ambientalismo", el cual, si bien puede reconocer obligaciones respecto de la naturaleza, no asigna a esta el carácter de titular de derechos ${ }^{30}$.

Como se dijo, la propuesta kantiana ha sido trasladada al discurso de los derechos humanos a través del «derecho al ambiente sano», y este, si bien ha logrado importantes avances en materia de protección ambiental bajo la idea de que preservar aquellos recursos naturales necesarios para la supervivencia del hombre es un imperativo para la satisfacción de los bienes jurídicos protegidos por los instrumentos de derechos humanos, estos avances no se han ocupado de la inherente tensión entre su fundamento liberal-antropocéntrico y el cuidado de la naturaleza. De ahí que autores como Häberle consideren que si bien de la idea de protección del

${ }_{25} \mathrm{Al}$ respecto Kant, en su obra «Lecciones de ética», diría: «Aquello de lo que el hombre puede disponer han de ser cosas. A este respecto los animales son considerados como cosas». KANT, I., Lecciones de ética, Crítica, Barcelona, 1988 [1775-1781], pp. 191 y 192.

${ }^{26}$ Kant, I., op. cit, 1876 [1790], p. 119.

27 Kant, I., op. cit, 1988 [1775-1781], p. 290.

28 Idem nota 25.

29 Nussbaum, M., op. cit, 2007, p. 331.

30 Zaffaroni, E., op. cit, 2011, p. 69. 
ambiente puede llegarse a un antropocentrismo moderado, con ello no encontramos, todavía, un Kant «verde» ${ }^{31}$.

En efecto, tal como lo ha establecido Dobson, aunque el ambientalismo y el liberalismo pueden ser compatibles, no así el ecologismo y el liberalismo ${ }^{32}$. Para los liberales clásicos la facultad que se debe poseer para tener derecho a la consideración moral es la razón, para los liberales utilitaristas, como vimos, es la capacidad de sentir; sin embargo, el enfoque ecocéntrico va más allá, en este las facultades a tener en cuenta son la autorreproducción o la autorrenovación, lo que, como expone Dobson,

amplía la comunidad de «pacientes morales» más allá de lo que se encuentra incluso en Mill y Bentham, y proporciona pruebas circunstanciales de que, por mucho que lo intenten, los liberales no encontrarán mucho en su legado histórico para satisfacer a los ecocéntricos ${ }^{33}$.

Además, el «derecho al ambiente sano», como se dijo, sigue viendo al ambiente como un recurso que el ser humano tiene derecho a utilizar. Esto se enfrenta con la tesis de los «límites al crecimiento», para la cual los ecosistemas naturales tienen una capacidad de carga limitada, por lo que simplemente no pueden soportar todos los derechos que una humanidad en crecimiento podría reclamar ${ }^{34}$. Así, parece claro que el liberalismo antropocéntrico, por sí solo, carece de los recursos intelectuales para hacer frente a los problemas relacionados con los objetivos ambientales de los derechos humanos ${ }^{35}$.

Frente a esto y, por otro lado, el ecocentrismo mira a la crisis ambiental como una crisis ética, lo que significa que el mantener modelos de desarrollo insostenibles es un problema ético más que uno exclusivamente político o económico ${ }^{36}$. Propone un holismo moral, esto es, al todo, los ecosistemas, la biósfera, como sede de valor. Parte de la idea de que la tierra no es únicamente suelo, sino una fuente de energía que fluye a través de un circuito de suelos, plantas y animales que hacen posible la vida, en un proceso de interrelación continua entre los seres vivos y la materia inerte ${ }^{37}$. De aquello desprende una nueva ética que mira al oikós, a la casa grande $^{38}$, una ética de la tierra la cual, en palabras de Leopold, «ensancha las fron-

31 Häberle, P., El estado constitucional, Pontificia Universidad Católica del Perú, Lima, 2003, p. 116.

32 Dobson, A., Green Political Thought $4^{\text {th }}$ edition, Routledge, Abingdon, 2007, p. 50.

33 Dobson, A., op. cit, 2007, p. 155. Traducción propia.

${ }^{34}$ Hayward, T., Ecological Thought: An Introduction, Polity Press, Oxford, 1995, pp. 144-

145.

35 Dobson, A., op. cit, 2007, p. 155. Traducción propia.

36 Woods, K., Human Rights and Environmental Sustainability, Edward Elgar Publishing Limited, Cheltenham, 2010, p. 74.

${ }^{37}$ Leopold, A., Una ética de la tierra, Los Libros de la Catarata, Madrid, 2017, p. 193.

38 Sosa, N.M., Ética ecológica, Necesidad, posibilidad, justificación y debate, Libertarias/ Prodhufi, 1994, p. 121. 
teras de la comunidad para incluir suelos, agua, plantas y animales, o de manera colectiva, la tierra ${ }^{39}$.

El eje central del ecocentrismo se encuentra en el reconocimiento de la naturaleza como titular de derechos propios, con independencia del humano. Así, su traducción normativa son los derechos de la naturaleza. Estos exigen la preservación de los ciclos vitales de la naturaleza y la recuperación de ecosistemas dañados. Al respecto, es importante precisar que, desde el ecocentrismo, el ser humano se constituye como parte de ese todo llamado naturaleza, de ahí que los derechos de la naturaleza, a diferencia de los derechos de los animales, no puedan olvidar que las dinámicas ecológicas implican, también, relaciones de competencia y depredación en las que se incluye el humano. Por ello, tal como lo señaló Aldo Leopold, una ética de la tierra, por supuesto, no puede impedir la alteración, la gestión y el uso de los recursos naturales; "pero afirma su derecho a continuar existiendo y, al menos en algunos puntos, a continuar existiendo en estado natural $»^{40}$. Así, el ecocentrismo reconoce y defiende la necesidad de intervenir en el entorno para satisfacer nuestras «necesidades vitales», pues los valores propios del humano son una parte de ese amplio conjunto de valoraciones a considerar ${ }^{41}$. Estas características hacen que, en nuestra consideración, este enfoque también pueda encontrar una traducción en el discurso de los derechos humanos, pues no discute la existencia de intereses antropocéntricos, sino que los incorpora como parte de las relaciones que se dan en el mundo natural. Propone, entonces, una redefinición de lo humano, dando cuenta de la parte de nosotros que se constituye a partir de nuestra relación con la naturaleza y, por esta vía, una fundamentación posible de los derechos humanos de vocación ecocéntrica.

Con este marco, a continuación, presentaré cómo se ha desarrollado la visión antropocéntrica del derecho instrumental al medio ambiente sano dentro de la Corte IDH, dando cuenta de sus características y limitaciones. Precisado lo anterior, daré argumentos dirigidos a demostrar por qué la reciente categorización del mismo derecho como «autónomo» se diferencia de la protección antropocéntrica y se acerca a una visión ecocéntrica del ser humano.

39 Leopold da cuenta de cómo en un primer momento la ética se ocupó de la relación entre los individuos; en un segundo momento, de las relaciones de los individuos con la sociedad, y que, actualmente, es necesaria la transición hacia un tercer momento, la extensión de la ética a la naturaleza, es decir, a la relación del ser humano con la tierra, los animales y las plantas que crecen en ella. LeOpold, A., op. cit., 2017, pp. 181 y 182.

${ }^{40}$ LeOpold, op. cit., 2017, p. 182.

${ }^{41}$ Gudynas, E., «La senda biocéntrica: Valores intrínsecos, derechos de la naturaleza y justicia ecológica», Tabula Rasa: Revista de humanidades, núm. 13, 2010, pp. 45-71. 


\section{EL DERECHO AL MEDIO AMBIENTE SANO COMO DERECHO INSTRUMENTAL}

La multiplicidad de posiciones que se depositan dentro del derecho al medio ambiente ha provocado que dentro de la dogmática de los derechos resulte especialmente complejo determinar sus facultades y, por ende, su categorización; de ahí que autores como Alexy lo consideren un «derecho fundamental como un todo», pues, en sus palabras,

quien propone el establecimiento de un derecho fundamental al medio ambiente, o su adscripción interpretativa a las disposiciones de derecho fundamental existentes puede, por ejemplo, incluir en este conjunto o haz de posiciones, un derecho a que el estado omita determinadas intervenciones en el medio ambiente (derecho de defensa), un derecho a que el Estado proteja al titular del derecho fundamental frente a intervenciones de terceros que dañen el ambiente (derecho de protección), un derecho a que el Estado permita participar al titular del derecho en procedimientos relevantes para el medio ambiente (derecho al procedimiento) y un derecho a que el propio Estado emprenda medidas fácticas, tendientes a mejorar el ambiente (derecho a una prestación fáctica ${ }^{42}$.

Siguiendo la complejidad señalada, la fundamentación del derecho humano al medio ambiente resulta, también, de difícil categorización dentro del sistema interamericano. De esto da cuenta la Opinión Consultiva N. ${ }^{\circ}$ OC-23/17 de la Corte Interamericana de Derechos Humanos, de fecha 15 de noviembre de 2017, sobre medio ambiente y Derechos Humanos. En esta opinión se da respuesta, entre otras, a la consulta formulada por la República de Colombia sobre las obligaciones de los Estados en relación con el medio ambiente en el marco de la protección y garantía de los derechos a la vida y a la integridad personal. Se constituye, de esta forma, en un hito importante en la protección del medio ambiente en el campo del derecho internacional de los derechos humanos, pues, mediante ella, la Corte IDH desarrolla, por primera vez de manera extendida, la relación entre los derechos civiles y políticos y el contenido del derecho al medio ambiente sano consagrado de forma expresa en el artículo 11 del Protocolo de San Salvador.

Bajo este parámetro interpretativo la Corte IDH ha considerado la protección del medio ambiente como un elemento sine qua non para el disfrute de otros derechos humanos. Esta aproximación se enmarca en lo que varios autores -e inclusive la Corte IDH-denominan un enfoque instrumental de la protección del medio ambiente para la garantía de los derechos humanos y, en la vertiente inversa, un enfoque instrumental de los derechos humanos para la protección del medio ambiente. Así, la Corte ha clasificado los derechos especialmente vinculados al medio ambiente en dos grupos: I) los derechos cuyo disfrute es particularmente vulnerable a la degra-

${ }^{42}$ Alexy, R., Teoría de los derechos fundamentales, 2da ed., Centro de Estudios Políticos y Constitucionales, Madrid, 2007, p. 392. 
dación del medio ambiente, también identificados como derechos sustantivos, y II) los derechos cuyo ejercicio respalda una mejor formulación de políticas ambientales, también identificados como derechos de procedimiento. Estas dos formas de entender la protección del medio ambiente en el derecho internacional de los derechos humanos, ambas con un eje antropocéntrico, desarrollan el contenido principal de la opinión consultiva, el cual pasaré a detallar brevemente.

\subsection{El enfoque instrumental de la protección del medio ambiente para LA GARANTÍA DE LOS DERECHOS HUMANOS}

Desde el enfoque instrumental de la protección del medio ambiente para la garantía de los derechos humanos, la Corte IDH ha considerado que existe una relación de interdependencia e indivisibilidad entre los derechos humanos, el medio ambiente y el desarrollo sostenible, pues todos los derechos humanos son vulnerables a la degradación ambiental ${ }^{43}$. Sin embargo, ha indicado la Corte, existen derechos especialmente vulnerables a afectaciones ambientales, entre los que se encuentran los derechos a la vida, integridad personal, vida privada, salud, agua, alimentación, vivienda, participación en la vida cultural, propiedad, el derecho a no ser desplazado forzadamente y otros relacionados de forma indirecta como el derecho a la paz ${ }^{44}$. En particular, es especialmente fructífera la jurisprudencia de la Corte sobre protección ambiental en casos de derechos territoriales de pueblos indígenas. En estos casos la Corte IDH ha resaltado que la falta de acceso a los territorios y recursos naturales puede exponer a las comunidades indígenas a condiciones de vida de mayor vulnerabilidad ante enfermedades, además de ocasionarles sufrimiento y perjudicar la preservación de su forma de vida, costumbres e idioma ${ }^{45}$.

En esta línea, en la OC-23/17, la Corte detalla el contenido y alcance general de las obligaciones de respetar y garantizar los derechos a la vida y a la integridad personal en relación con afectaciones producidas por dańos al medio ambiente ${ }^{46}$. Así, en primer lugar, para garantizar las obligaciones de respeto que, en términos de Alexy, desarrollarían la vertiente de derecho de defensa del derecho a un medio ambiente sano, la Corte ha establecido que los Estados deben «abstenerse de contaminar ilícitamente el medio ambiente de forma que se afecte las condiciones que

43 Corte IDH, Opinión Consultiva OC-23/17, párrs. 54 y 63.

${ }^{44}$ Corte IDH, Opinión Consultiva OC-23/17, párr. 66.

45 Entre otros: caso Comunidad Indígena Yakye Axa vs. Paraguay. Fondo Reparaciones y Costas. Sentencia 17 de junio de 2005, párr. 137; caso Comunidad Indígena Sawhoyamaxa vs. Paraguay. Fondo, Reparaciones y Costas. Sentencia de 29 de marzo de 2006, párr. 118; caso del Pueblo Saramaka vs. Surinam. Excepciones Preliminares, Fondo, Reparaciones y Costas. Sentencia de 28 de noviembre de 2007, párrs. 121 y 122, y caso Pueblos Kaliña y Lokono vs. Surinam. Fondo, Reparaciones y Costas. Sentencia de 25 de noviembre de 2015, párr. 173.

46 Corte IDH, Opinión Consultiva OC-23/17, párr. 242. 
permiten la vida digna de las personas $»^{47}$. En segundo lugar, respecto de la obligación de garantizar, en la que, siguiendo la clasificación de Alexy, podríamos incluir las vertientes de derecho a la protección y a una prestación fáctica, la Corte ha considerado que los Estados deben adoptar todas las medidas apropiadas para proteger y preservar los derechos a la vida y a la integridad, debiendo prevenir, inclusive, que particulares vulneren dichos derechos. Así, especifica la Corte, «en el marco de la protección del medio ambiente, la responsabilidad internacional del Estado derivada de la conducta de terceros puede resultar de la falta de regulación, supervisión o fiscalización de las actividades de estos terceros que causen un dańo al medio ambiente» ${ }^{48}$.

Las obligaciones específicas que emanan de esta vertiente instrumental del derecho a un medio ambiente sano, conforme lo establece la Corte, son 1) actuar conforme al principio de prevención frente a daños ambientales significativos. Para el cumplimiento de esta obligación los Estados deben regular, supervisar y fiscalizar las actividades que puedan causar un daño significativo al medio ambiente; requerir y aprobar estudios de impacto ambiental; establecer un plan de contingencia para minimizar la posibilidad de grandes accidentes ambientales, y mitigar en casos de ocurrencia de daño ambiental ${ }^{49}$; 2) actuar conforme al principio de precaución cuando haya indicadores plausibles de que una actividad podría acarrear daños graves e irreversibles al medio ambiente, aun en ausencia de certeza científica, a efectos de la protección del derecho a la vida y a la integridad personal ${ }^{50}$, y 3 ) cooperar de buena fe con otros Estados para la protección contra daños al medio ambiente, notificando a estos cuando tengan conocimiento de que una actividad planificada bajo su jurisdicción podría generar un riesgo de daños significativos transfronterizos, así como consultando y negociando, de buena fe, con los Estados potencialmente afectados ${ }^{51}$.

\subsection{El ENFOQUE INSTRUMENTAL DE LOS DERECHOS HUMANOS PARA LA PROTECCIÓN DEL MEDIO AMBIENTE}

Desde un enfoque instrumental de los derechos humanos para la protección del medio ambiente, la Corte IDH ha establecido que existe un grupo de obligaciones que, en materia ambiental, se identifican como de procedimiento. Estas respaldan una mejor formulación de las políticas ambientales e integrarían la faceta de derecho al procedimiento del derecho al medio ambiente sano expuesta por Alexy. En este marco, la Corte detalla las obligaciones de los Estados sobre los derechos a 1) el acceso a la información; 2) la participación pública; y 3) el acceso a la justicia, en relación con las obligaciones estatales para la protección del medio ambiente.

47 Corte IDH, Opinión Consultiva OC-23/17, párr. 117.

${ }^{48}$ Corte IDH. Opinión Consultiva OC-23/17, párrs. 118-119.

${ }^{49}$ Corte IDH, Opinión Consultiva OC-23/17, párrs. 145-174.

${ }^{50}$ Corte IDH, Opinión Consultiva OC-23/17, párr. 180.

${ }^{51}$ Corte IDH, Opinión Consultiva OC-23/17, párr. 185. 
Sobre el acceso a la información, en su vertiente pasiva, es decir, sobre el derecho a recibir respuestas ante las solicitudes de información efectuadas, la Corte ha categorizado como de interés público las actividades y proyectos que podrían tener impacto ambiental ${ }^{52}$. Por esta razón, la información relativa a dichas actividades debe ser entregada sin necesidad de acreditar un interés directo para su obtención o una afectación personal ${ }^{53}$. Por otro lado, la garantía de este derecho incluye, además, la obligación positiva del Estado de suministrar, de oficio, información completa, comprensible, accesible y actualizada sobre la calidad ambiental, el impacto ambiental en la salud, los factores que lo influencian y sobre la legislación y las políticas relativas al medio ambiente ${ }^{54}$.

Sobre el derecho a la participación pública, la Corte ha establecido que los Estados tienen la obligación de garantizar la participación de las personas en la toma de decisiones y políticas que puedan afectar el medio ambiente. Este derecho debe ser garantizado desde las primeras etapas del proceso de toma de decisiones y puede realizarse siguiendo mecanismos tales como audiencias públicas; notificación y consultas; participación en procesos de formulación y aplicación de leyes, y mecanismos de revisión judicial55. En específico, sobre comunidades indígenas, la Corte ha establecido que se debe garantizar su derecho a la consulta y participación en todas las fases de planeación e implementación de un proyecto o medida que pueda afectar su territorio, de conformidad con sus costumbres y tradiciones ${ }^{56}$.

Finalmente, la Corte ha establecido que el derecho al acceso a la justicia permite al individuo velar por que se apliquen las normas ambientales y exigir que se repare cualquier violación a los derechos humanos causada por su incumplimiento. Así,

los Estados deben garantizar que los individuos tengan acceso a recursos, sustanciados de conformidad con las reglas del debido proceso legal, para impugnar cualquier norma, decisión, acto u omisión de las autoridades públicas que contraviene o puede contravenir las obligaciones de derecho ambiental; para asegurar la plena realización de los demás derechos de procedimiento, es decir, el derecho al acceso a la información y la participación pública, y para remediar cualquier violación de sus derechos, como consecuencia del incumplimiento de obligaciones de derecho ambiental ${ }^{57}$.

52 Caso Pueblo Indígena Kichwa de Sarayaku vs. Ecuador. Fondo, Reparaciones y Costas. Sentencia de 27 de junio de 2012, párr. 230; caso Claude Reyes y otros vs. Chile. Fondo, Reparaciones y Costas. Sentencia de 19 de septiembre de 2006, párr. 73.

${ }^{53}$ Caso Claude Reyes y otros vs. Chile, 2006, párr. 77 y caso Pueblos Kalińa y Lokono vs. Surinam. Fondo, Reparaciones y Costas. Sentencia de 25 de noviembre de 2015, párr. 261.

${ }^{54}$ Corte IDH, Opinión Consultiva OC-23/17, párrs. 213-225.

55 Corte IDH, Opinión Consultiva OC-23/17, párrs. 226-232.

56 Caso del Pueblo Saramaka vs. Surinam. Excepciones Preliminares, Fondo, Reparaciones y Costas. Sentencia de 28 de noviembre de 2007, párr. 133.

57 Corte IDH, Opinión Consultiva OC-23/17, párr. 237. 
Como se ve, los mecanismos que ha establecido la Corte para la protección del ambiente por medio del argumento de conexión son diversos y constituyen, sin duda, un importante avance en la materia. Sin embargo, el enfoque antropocéntrico kantiano al que responden hace que, en nuestra consideración, estos avances sean aún insuficientes. Bajo estos modelos el derecho al medio ambiente sano, ya sea en su vertiente individual o colectiva, sigue estando concebido en función de los intereses de las personas humanas.

Como lo expresó la Corte IDH en el párrafo 59 de la OC-23/17, en su dimensión individual, el derecho al medio ambiente sano constituye un elemento cuya vulneración puede tener repercusiones directas o indirectas sobre las personas. En esta faceta la protección de la naturaleza es relevante en tanto en cuanto su degradación afecte un bien jurídico de un ser humano. Del mismo modo, sobre su vertiente colectiva, la Corte sostiene que este derecho constituye un interés universal que se debe tanto a las generaciones presentes como a las futuras. Así, aunque no haya que observar deber alguno hacia la naturaleza considerada en sí misma, hay que tener en cuenta a las demás personas.

De esta postura, como se expuso anteriormente, nace la sostenibilidad como un complemento a la idea del desarrollo en favor de la continuidad exclusiva de la especie humana, ubicando al ser humano como el único sujeto de derechos. Ya hemos indicado en el apartado segundo los riesgos que para la naturaleza trae el fundamentar su protección, de forma exclusiva, en su utilidad para el ser humano. La consideración del ser humano como el fin último del reino de los fines -base de esta aproximación- hace que los argumentos que se pueden dar a favor de la afectación del ambiente, siguiendo objetivos antropocéntricos, sean infinitos. De ahí que, en nuestra consideración, una apuesta fuerte por la garantía de la naturaleza como un bien en sí mismo sea un complemento necesario, tal como parece dar cuenta la Corte IDH en la vertiente autónoma del derecho al medio ambiente sano, la cual pasaré a exponer a continuación.

\section{EL DERECHO AL MEDIO AMBIENTE SANO COMO DERECHO AUTÓNOMO}

Si bien los aportes de la OC-23/17 sobre el derecho a un medio ambiente sano se efectúan, principalmente, por su relación con los derechos a la vida e integridad física, en mi opinión, uno de los puntos que mayor impacto ofrecen es el reconocimiento expreso del derecho a un medio ambiente sano como un derecho autónomo en el sistema interamericano de protección de derechos. Este derecho, como ya se dijo, fue declarado como vulnerado, por primera vez en un caso contencioso, en la reciente sentencia del caso comunidades indígenas miembros de la Asociación Lhaka Honhat (nuestra tierra) vs. Argentina, de 6 de febrero de 2020. En el presente apartado me referiré al desarrollo jurisprudencial de este derecho tomando como base estas dos resoluciones de la Corte.

Así, en el párrafo 25 de la Opinión Consultiva, la Corte IDH establece que, dada la estrecha conexión entre la protección del medio ambiente con el desarrollo 
sostenible y los derechos humanos, actualmente diversos sistemas de protección de derechos humanos y, en particular, el Sistema Interamericano de Derechos Humanos reconocen el derecho al medio ambiente sano como un derecho en sí mismo. En el párrafo 62 desarrolla el contenido de este derecho declarando que, «a diferencia de otros derechos, este protege los componentes del medio ambiente tales como bosques, ríos, mares y otros como intereses jurídicos en sí mismos, aún en ausencia de certeza o evidencia sobre el riesgo a las personas individuales». Finalmente, precisa que el derecho al medio ambiente sano como derecho autónomo busca

proteger la naturaleza y el medio ambiente no solamente por su conexidad con una utilidad para el ser humano o por los efectos que su degradación podría causar en otros derechos de las personas, como la salud, la vida o la integridad personal, sino por su importancia para los demás organismos vivos con quienes se comparte el planeta, también merecedores de protección en sí mismos.

El contenido de este derecho ha sido, a su vez, ratificado en párrafo 203 de la sentencia del caso Lhaka Honhat vs. Argentina, con lo cual, la Corte parece reconocer un nuevo bien jurídico dentro del sistema interamericano, la naturaleza en sí misma. Siguiendo lo dicho por el profesor Simón Yarza, si el derecho a un medio ambiente sano consistiese únicamente en las condiciones necesarias para asegurar bienes fundamentales como la vida, la integridad física o la propiedad, la pretendida sustantividad propia del derecho desaparecería y su reconocimiento sería solo testimonial. Por ello, «un derecho al medio ambiente que no sea un mero corolario de otros derechos ya reconocidos habría de tener por objeto ora nuevos bienes jurídicos individuales, ora el medio ambiente como bien colectivo (la protección del entorno o de la naturaleza como tales) ${ }^{58}$. En este marco, el desarrollo del derecho al medio ambiente como derecho autónomo podría constituir un esfuerzo por sustantivar este derecho desde un enfoque ecocéntrico.

Si bien ni en la opinión consultiva ni en la sentencia del caso Lhaka Honnat se desarrollan las obligaciones específicas que nacen de este nuevo derecho autónomo, considero que tomando como referencia las puntualizaciones que se hacen respecto del mismo se pueden obtener ciertos rasgos que nos permiten dar cuenta de por qué esta construcción parece alejarse de la titularidad antropocéntrica individual o colectiva del derecho al medio ambiente.

Se podría creer, por ejemplo, que la consagración del derecho a un medio ambiente sano como un derecho autónomo es una respuesta a la dimensión humana colectiva de este derecho. La preservación de los componentes del medio ambiente podría ser un mecanismo para evitar un proceso de degradación ambiental que ponga en riesgo a toda la humanidad. Sin embargo, considero que la Corte IDH va un paso más allá al definir este derecho, pues, como reza en el antes citado párrafo 62 de la OC-23/17, lo que busca es proteger a la naturaleza y el medio ambiente no sola-

58 Simón Yarza, F., Medio ambiente y derechos fundamentales, Centro de Estudios Políticos y Constitucionales, Madrid, 2012, p. 64. 
mente por su conexidad con una utilidad para el ser humano o por los efectos que su degradación podría causar en otros derechos de las personas, sino por su importancia para los demás organismos vivos con quienes se comparte el planeta, también merecedores de protección en sí mismos. En este caso, a diferencia de la dimensión humana-colectiva de este derecho, la Corte pone el acento en la protección que ofrece para los demás organismos no humanos. Así, el objetivo no es ya conservar la humanidad, sino a todos los organismos que conviven con ella.

Esta particularidad ubica al desarrollo jurisprudencial efectuado por la Corte IDH más cercano a las reivindicaciones del modelo ecocéntrico de acuerdo con el cual la naturaleza posee fines y valores en sí misma, pudiéndose predicar una dignidad de ella. La definición que da la Corte sobre la vertiente autónoma de este derecho reconoce que existen algunos perjuicios ambientales que no solamente afectan a los seres humanos, sino, también, a otros habitantes del planeta. En este contexto, parece que la Corte ha buscado dar un paso más, comprendiendo que, como lo expresa el juez Zaffaroni, la naturaleza, el planeta, la Tierra, la Pachamama, es otro ente con el que podemos dialogar y, más aún, con el que debemos dialogar ${ }^{59}$.

Esta precisión nos permite identificar, también, las distancias entre el desarrollo jurisprudencial de la Corte IDH, que en nuestra opinión deriva de la incorporación del enfoque ecocéntrico, de otras posturas como la del enfoque de las capacidades de Nussbaum. Como se expuso anteriormente, Nussbaum limita el reconocimiento de derechos para aquellas especies sensibles, pues solo de estas se puede identificar el dolor causado por el ser humano como una barrera para el libre desarrollo de sus capacidades naturales. Por el contrario, una postura ecocéntrica, como la que propone la ética Pachamama, reconoce la titularidad de derechos no solo para entes sensibles, sino para todo el entorno, incluidos entes que podríamos llamar inertes. De esta forma, la ética de la Pachamama, como le expresa Zaffaroni,

busca reconocer que debemos actuar respetando a otros seres con derechos y cuyo reconocimiento es condición de nuestra propia supervivencia como especie interdependiente de otras y de otros entes terrenos en su existencia, es un fortalecimiento de la capacidad de escucharnos entre nosotros y de escuchar lo que nos dicen todos los demás entes del planeta ${ }^{60}$.

Considero relevante la referencia al trabajo académico del juez Eugenio Zaffaroni, pues da cuenta de que en el debate llevado en el seno de la Corte IDH existía plena conciencia de los efectos del reconocimiento del derecho a un medio ambiente sano como derecho autónomo. Esto parece claro al examinar los votos particulares del juez Humberto Sierra Porto tanto en la OC 23/17 como en el caso Lhaka Honhat vs. Argentina, en los cuales da a conocer su discrepancia, justamente, respecto de la decisión de la mayoría en este punto. Parece entonces que la Corte se aleja de los esquemas filosóficos occidentales y se nutre de la cosmovisión de los pueblos indí-

59 Zaffaroni, op. cit., 2011, p. 125.

60 Zaffaroni, op. cit., 2011, p. 134. 
genas de la América Andina para fundamentar un nuevo derecho que revoluciona la idea de dignidad humana incorporando una comprensión holística de su concepto.

La pregunta es entonces ¿cuál es el contenido del derecho al medio ambiente derivado de un enfoque ecocéntrico? y ¿se podrían trasladar las garantías de procedimiento dadas a la versión antropocéntrica de este derecho a este nuevo enfoque ecocéntrico? Al respecto resulta interesante revisar el debate doctrinal citado por Navarro Mendizábal. Para un sector de la doctrina, si no es posible proteger el derecho a un medio ambiente abstracto y mal definido, se puede muy bien dar el derecho a cada uno de actuar cuando su medio ambiente es objeto de discusión, mediante los derechos de información, participación y tutela judicial. El contenido del derecho al medio ambiente así planteado es ante todo procedimental y no sustantivo. Por otro lado, otro sector de la doctrina, en el que destaca Loperena Rota, presenta como un absurdo que nos conformemos con que se nos reconozcan a los ciudadanos dichos derechos de participación, esto implicaría no respetar las reglas de lógica jurídica negando la sustantividad de un derecho y proponiendo su tutela. Si no hay derecho sustantivo, ¿a qué se orienta la participación o la tutela judicial? Como lo menciona Navarro, desde una perspectiva teórica, cabe reconocer un derecho y no disponer de un sistema adecuado de protección, pero nunca al revés $^{61}$. En línea con la segunda postura, considero que la garantía de un derecho al medio ambiente sano como derecho autónomo derivado de un enfoque ecocéntrico exige la elaboración de un contenido sustancial del mismo. En dicha tarea, el concepto desarrollado por la Corte Interamericana de daño ambiental significativo nos puede arrojar algunas luces.

En el párrafo 120 de la OC-23/17 la Corte IDH establece que para que surjan obligaciones positivas hacia el Estado debe existir una relación de causalidad entre la afectación a la vida o a la integridad y el dańo significativo causado al medio ambiente. Conforme lo expone la Corte IDH, cualquier daño al medio ambiente que pueda conllevar una violación de los derechos a la vida o a la integridad personal debe ser considerado como un daño significativo. La existencia de un daño significativo en estos términos es algo que deberá determinarse en cada caso concreto, con atención a las circunstancias particulares del mismo. Esto quiere decir que las obligaciones deben cumplirse bajo un estándar de debida diligencia, el cual debe ser el apropiado y proporcional al grado de riesgo de dańo ambiental. De esta forma, las medidas que un Estado deba adoptar para la conservación de ecosistemas frágiles serán mayores y distintas a las que corresponda adoptar frente al riesgo de daño ambiental de otros componentes del medio ambiente y estas pueden variar con el tiempo, por ejemplo, con base en descubrimientos científicos o nuevas tecnologías ${ }^{62}$.

${ }^{61}$ Navarro Mendizábal, I., «El derecho a un medio ambiente adecuado, ¿̨es un derecho?», en Desafios actuales a los derechos humanos: el derecho al medio ambiente y sus implicaciones, Debates del Instituto Bartolomé de las Casas (pp. 64-91), Dykinson, Madrid, 2009, pp. 79-80.

${ }^{62}$ Corte IDH, Opinión Consultiva OC-23/17, párr. 140. 
Esta idea del daño significativo ambiental desarrollada como núcleo sustantivo de la versión antropocéntrica del derecho al medio ambiente sano, en mi opinión, podría ser trasladada a la protección de la naturaleza como un bien jurídico en sí mismo. Se afectaría entonces el contenido sustancial de este derecho cuando la intervención humana amenace con obstruir los ciclos vitales de la naturaleza, cuando impida la continuación de los procesos de cooperación existentes entre los organismos que conforman el entorno. Este daño responderá también a la evolución de la ciencia. El desarrollo de la tecnología verde podría hacer que una intervención humana sobre el entorno natural que actualmente se pueda considerar dańina para sus ciclos vitales posteriormente no lo sea. Se crearía, además, un núcleo esencial de protección para ecosistemas frágiles, ya no en razón de su funcionalidad para el ser humano, sino porque en estos entornos cualquier tipo de intervención puede significar una alteración de sus procesos naturales.

Me parece también relevante referir un aspecto de la teoría de Nussbaum que, salvando la ya mencionada distancia que tiene esta con el ecocentrismo, puede complementar la identificación del daño significativo a la naturaleza. Para esta autora, los seres humanos no deben fiarse demasiado de suposiciones indirectas sobre las capacidades animales; por el contrario, deben tratar de observar qué es lo que cada criatura considera importante basándose en lo que esta hace. Así, para Nussbaum, parte del respeto por otras especies se manifiesta a través de la disposición a observar y estudiar aprendiendo los ritmos internos de una comunidad animal y la noción de valor que su modo de vida expresa ${ }^{63}$. Este desarrollo puede ser trasladado también a la protección más amplia que provee el ecocentrismo aplicando la observación ya no solo con los seres sensibles, sino con toda la naturaleza. Dicha observación permitirá un diálogo respetuoso entre especies sobre el cual construir la armonía que protege la Pachamama.

Esta concepción implica, por tanto, cambios sustanciales en la idea de dignidad humana y, por esta vía, de los sujetos capaces de activar el sistema interamericano de derechos humanos como víctimas. En la Opinión Consultiva N. ${ }^{\circ}$ OC-22/16, del 26 de febrero de 2016, sobre titularidad de derechos de las personas jurídicas en el sistema interamericano, la Corte Interamericana estableció que conforme al artículo 1.2 de la Convención los derechos reconocidos en dicho instrumento corresponden a únicamente a personas, es decir, a seres humanos. Lo anterior implica que en el marco de la Convención Americana las personas jurídicas no son titulares de los derechos establecidos en esta y, por tanto, no pueden presentar peticiones o acceder directamente, en calidad de presuntas víctimas.

A este criterio respondió la Comisión Interamericana de Derechos Humanos en el año 2004 al declarar inadmisible la petición presentada por un ciudadano panameño respecto del Parque Natural Metropolitano en Panamá, dado que la petición no individualizaba víctimas concretas y era excesivamente amplia. El peticionario alegaba que el Gobierno había violado el derecho a la propiedad de todos los

${ }^{63}$ Nussbaum, op. cit., 2007, p. 366 
ciudadanos panameños al permitir la construcción de un proyecto vial que atravesaba una reserva natural protegida. Después de ocho años, la Comisión determinó que, en vista de que no se habían identificado víctimas humanas específicas, la petición era inadmisible ${ }^{64}$.

La consagración del derecho a un medio ambiente sano como derecho autónomo promete cambiar esta jurisprudencia, pues al identificar a los bosques, ríos, mares y otros como intereses jurídicos en sí mismos, aun en ausencia de certeza o evidencia sobre el riesgo a las personas individuales, se crea un nuevo sujeto de protección de tipo abstracto en el marco del sistema interamericano. Esto significa abrir paso para que la naturaleza pueda ser considerada víctima, cambiando sustancialmente la jurisprudencia en esta materia. Al respecto, se pronuncia también el juez Zaffaroni en su libro La Pachamama y el humano, indicando que la mera circunstancia de que cualquiera puede accionar en defensa de la naturaleza, sin que sea menester invocar $-y$ menos probar- la condición de damnificado, provocará que diferentes personas, según sus simpatías con los entes naturales no humanos, ejerzan acciones en su defensa ${ }^{65}$.

Por último, el reconocimiento de la naturaleza como víctima para el sistema interamericano le otorga también la posible condición de tercero agredido. Esto, como lo manifiesta Zaffaroni, hace que sean lícitos en defensa de la naturaleza actos como las sentadas, colocación de obstáculos al avance de maquinarias de desmonte y otros medios de lucha no violenta ${ }^{66}$.

\section{CONCLUSIONES}

El cambio al paradigma ecocéntrico al que parece inclinarse la Corte Interamericana de Derechos Humanos, sin duda, representa un desafío hacia la construcción de una nueva epistemología difícilmente explicable dentro de las construcciones dogmáticas efectuadas a partir del enfoque antropocéntrico. Esta pone en cuestión la conceptualización misma de los derechos humanos como aquellos que se poseen por el hecho de ser persona; de ahí que, como lo expresa Zaffaroni, requiera de una nueva jurisprudencia, cuyas consecuencias prácticas son de momento difíciles de prever, pero lo cierto es que no responderá a los criterios que hasta el presente se vienen manejando ${ }^{67}$.

En mi opinión, lo anterior no constituye un debilitamiento del poder emancipador de la idea de los derechos humanos; por el contrario, abre las puertas hacia una interpretación holística capaz de nutrirse no solo de los postulados clásicos, sino,

${ }^{64}$ Shelton, D., «Derechos ambientales y obligaciones en el sistema interamericano de derechos humanos", en Anuario de Derechos Humanos de la Universidad de Chile, número 6 (pp. 111127), 2010, p. 126.

${ }_{65}$ ZafFaroni, op. cit., 2011, p. 141

${ }^{66}$ ZafFaroni, op. cit., 2011, p. 142

67 Zaffaroni, op. cit., 2011, p. 144 
además, de aquellas otras cosmovisiones históricamente relegadas dentro del debate doctrinal, tales como las provenientes de los pueblos de la América Andina y en particular de la ética de la Pachamama. De esta forma se podrá otorgar un mayor grado de protección a la naturaleza, a aquello que es inherente al ser humano no como su piloto sino como un pasajero más. Como lo expresa Boaventura de Sousa, la evolución del derecho en los últimos 50-60 años ha demostrado que el mejor mecanismo jurídico para garantizar la eficacia de los derechos es la existencia de garantías que den forma real a esos derechos; en el caso de la naturaleza esa dignidad y esa sobrevivencia solo se puede garantizar efectivamente dándole titularidad de derechos ${ }^{68}$.

ReCiBIDO: septiembre de 2020; ACEPTADO: diciembre de 2020

${ }^{68}$ De Sousa Santos, B., Derecho y emancipación, Centro de Estudios y Difusión del Derecho Constitucional-Corte Constitucional de Ecuador, Quito, 2012, p. 23. 



\title{
TRATADOS BILATERALES DE INVERSIÓN Y DERECHOS HUMANOS: TRES POSICIONES DESDE AMÉRICA LATINA
}

\author{
Lucas Sebastián de Erice Aranda* \\ Universidad de La Laguna
}

\section{RESUMEN}

Este artículo tiene como objeto analizar el modo en el cual la firma de nuevos tratados bilaterales de inversión puede llegar a convertirse en una limitación autoimpuesta por los Estados a su capacidad de cumplimiento de sus obligaciones en materia de derechos humanos. Para ello se analizarán las principales características de dichos acuerdos y los puntos de fricción más importantes con el Derecho Internacional de los Derechos Humanos. Así mismo, se estudiarán las posibles vías de acción que tienen a su disposición los Estados para tratar de resolver dicha tensión, a través del estudio de tres ejemplos latinoamericanos: México, Ecuador y Brasil.

Palabras Clave: tratados bilaterales de inversión, obligaciones en materia de derechos humanos, autolimitación.

\section{BILATERAL INVESTMENT TREATIES AND HUMAN RIGHTS: \\ THREE POSITIONS FROM LATIN AMERICA}

\section{Abstract}

The purpose of this article is to analyze the way in which the signing of new bilateral investment treaties can become a self-imposed limitation by the States to their ability to comply with their human rights obligations. Therefore, the main characteristics of these agreements will be analyzed, as well as the main points of collision with the International Human Rights Law. Likewise, the possible courses of action that the States have at their disposal to try to resolve that tension will be studied, through the example of three Latin American countries: Mexico, Ecuador and Brazil.

KEYwords: bilateral investment treaties, obligations on human rights, self-imposed limitation. 


\section{INTRODUCCIÓN}

Las últimas décadas de globalización han dibujado un panorama mundial basado en una economía interdependiente en la que los Estados, sujetos originarios del Derecho Internacional Público (DPI), comparten escenario con las grandes empresas transnacionales (ETN). Estas corporaciones tienen miles, incluso millones de trabajadores, sedes e inversiones repartidas por todo el globo y una gran capacidad económica, capaz de competir con muchos países. Las empresas buscan oportunidades de negocio en todo el planeta, y los Estados tratan de atraer inversión extranjera que pueda incentivar su desarrollo económico. Para fomentar y gestionar este intercambio, surge el régimen de protección de las inversiones (RPI), un sistema mediante el que los Estados receptores de inversión tratan de generar un escenario atractivo y de cierta estabilidad jurídica para el desarrollo de actividades empresariales. Un elemento clave de dicho régimen son los tratados bilaterales de inversión (TBI), acuerdos internacionales entre dos Estados para fomentar la inversión privada que, como todo convenio de DPI, genera una serie de obligaciones recíprocas.

Estos acuerdos tienen como objetivo principal promover la inversión extranjera $^{1}$, motor de gran importancia para la economía y el desarrollo de todos los Estados. Para ello, tratan de garantizar la seguridad jurídica de las inversiones a través de una serie de cláusulas que protejan los intereses de los inversores extranjeros. Una de las principales características de estos tratados es la inclusión de un sistema de resolución de controversias inversor-Estado (ISDS) ${ }^{2}$ que permite a las propias empresas denunciar a los Estados por el posible incumplimiento de algunas de sus cláusulas. En ocasiones ante los tribunales nacionales, pero por lo general ante tribunales internacionales de arbitraje.

El primer TBI se firmó entre la República Federal de Alemania y la República Islámica de Pakistán en el año 1959, y en los años sesenta y setenta se convirtió en práctica habitual entre los países exportadores de capital y, en mayor medida,

* Universidad Autónoma de Madrid, doble graduado en Derecho y Ciencias Políticas y de la Administración Pública. Universidad Politécnica de Valencia, máster en Cooperación Internacional al Desarrollo. Universidad Carlos III, experto en Pueblos Indígenas, Derechos Humanos y Cooperación Internacional. Universidad de La Laguna, doctorando en el Programa de Doctorado en Derecho, Sociedad y Turismo.

${ }_{1}$ Pese a lo anterior, diversos autores ponen en duda que haya una relación directa entre TBI y aumento de la inversión extranjera. Neumayer, E. y Spess, L., «Do Bilateral Investment Treaties Increase Foreign Direct Investment to Developing Countries?», World Development, núm. 1 (3), 2005, pp. 31-49. Incluso la Conferencia de Naciones Unidas sobre el Comercio y el Desarrollo (UNCTAD) ha reconocido en varios informes que, dependiendo del método de análisis que se utilice, los TBI parecen tener muy poco o ningún efecto en los flujos de inversión extranjera directa entre el Norte y el Sur. Como veremos más adelante, en este sentido destaca el caso de Brasil, que pese a no tener ningún TBI en vigor es el mayor receptor de inversiones de Latinoamérica.

${ }^{2}$ En referencia a las siglas en inglés de Investor-State Dispute Settlement. 
Estados africanos y asiáticos ${ }^{3}$, alcanzando la cifra de 386 acuerdos en el año $1989^{4}$. A partir del Consenso de Washington ${ }^{5}$ de la mano de las políticas económicas basadas en la liberalización del mercado, la privatización de los servicios y la apertura a la inversión extranjera, se firmaron cientos de TBI a los que se incorporaron gradualmente la mayoría de los países latinoamericanos ${ }^{6}$. Sólo en la década de los noventa se firmaron 1600 acuerdos $^{7}$. El ritmo de celebración de nuevos tratados se mantuvo en el tiempo y, según datos de la Conferencia de Naciones Unidas sobre Comercio y Desarrollo (UNCTAD), en la actualidad existen 3284 TBI en vigor ${ }^{8}$.

Este artículo expondrá de qué manera dichos acuerdos pueden suponer una clara limitación, consciente y voluntaria, de la capacidad de los Estados de cumplir con otra serie de importantes obligaciones: aquéllas generadas por el Derecho Internacional de los Derechos Humanos (DIDH). Con este objetivo, en primer lugar, se efectúa un análisis de las principales características de los TBI, y se exponen los principales puntos de colisión con las obligaciones en materia de derechos humanos. En segundo lugar se estudian las alternativas de acción estatal ante tal tensión. Para ello se pone especial atención en el ámbito latinoamericano, región de gran interés para la temática ya que en la actualidad concentra gran parte de los debates políticos, doctrinales y jurídicos alrededor del RPI. Las alternativas de acción

${ }^{3}$ Férnandez de Gurmendi, S., «Los Convenios Bilaterales de promoción y protección de inversiones extranjeras», Relaciones Internacionales, núm. 1 (3), 1992. Disponible en https://revistas.unlp.edu.ar/RRII-IRI/article/view/2008.

${ }^{4}$ VANDEVelde, Kenneth J., "A Brief History of International Investment Agreements», UC Davis Journal of International Law \& Policy, vol. 12, núm. 1, 2005, pp. 157-194. Disponible en http://ssrn.com/abstract=1478757.

${ }^{5}$ Concepto acuñado por el economista británico John Williamson para definir el paquete de medidas de estabilización y ajuste económico acordadas por instituciones como el Fondo Monetario Internacional, el Banco Mundial y la Reserva Federal de Estados Unidos a finales de los ochenta. Entre las medidas destacaban la lucha contra el déficit público, las reformas para reducir los impuestos y desregular los mercados laborales, la privatización de servicios públicos o el fomento de la inversión extranjera directa (IED). Martínez Rangel, R. y Reyes Garmendia, E., «El Consenso de Washington: la instauración de las políticas neoliberales en América Latina», Politica Cultural, núm. 37, 2012, pp. 35-64. Disponible en http://www.scielo.org.mx/scielo.php?pid=S0188-77422012000100003\&script=sci_abstract.

${ }^{6}$ Esta demora en la incorporación de los países latinoamericanos se explica por el arraigo de las doctrinas Calvo y Drago en la región. Ambas defendían que los inversores extranjeros deben recibir el mismo trato que los inversores nacionales, por lo que no es necesario someterse a un arbitraje internacional. BeLLo, F., «La responsabilidad internacional del Estado. Las Doctrinas Calvo y Drago", Revista de Ciencias Jurídicas, núm. 16, 1970, p. 8. Disponible en https://revistas.ucr.ac.cr/ index.php/juridicas/article/view/16742/16236.

7 TRAIDCRAFT, Los acuerdos internacionales de inversión a examen. Traidcraft, 2015. Disponible en https://www.ecologistasenaccion.org/wp-content/uploads/adjuntos-spip/pdf/examen-acuerdos-internacionales-inversion.pdf.

${ }^{8}$ Según el World Investment Report publicado el 16 de junio de 2020. UNCTAD, World Investment Report 2020: International Production beyond the Pandemic. United Nations Conference on Trade and Development, 16 de junio de 2020. Disponible en https:/unctad.org/system/ files/official-document/wir2020_en.pdf. 
estatal se ilustran con tres ejemplos de posturas muy diferenciadas y significativas: I) México y su opción continuista, fiel al sistema tradicional de protección de inversiones; II) Ecuador y su decisión de impugnar el sistema, denunciando y abandonado todos sus TBI; y III) el especial caso brasileño, Estado que nunca ha firmado un TBI y que en la actualidad ofrece un mecanismo alternativo de gran interés.

\section{LOS TBI DE VIEJA Y NUEVA GENERACIÓN}

A partir de la década de 2010, muchos acuerdos firmados en los años noventa alcanzaron su fecha de finalización ${ }^{9}$ o el momento en el que podían ser abandonados unilateralmente por una de las partes. Esto dio lugar a un fenómeno hasta el momento inédito, ya que se comenzaron a negociar nuevas versiones de los tratados. Los Estados tenían la opción de replantearse su política al respecto y hacer las cosas de forma distinta, incluyendo disposiciones más adaptadas a las necesidades actuales, o incluso tomar la decisión de no firmar nuevos acuerdos de inversión. Consciente de la importancia del momento, también Naciones Unidas comenzó a señalar la necesidad de repensar los nuevos acuerdos de inversión, señalando que debían buscar la coherencia con las nuevas políticas mundiales ${ }^{10}$. Los intereses y prioridades políticas no eran los mismos que en la década de los noventa y por ello la UNCTAD, de la mano del nuevo marco aportado por los Objetivos de Desarrollo Sostenible, comenzó a diseñar una estrategia de renovación de los TBI y a destacar la necesidad de una nueva generación de acuerdos. Sus argumentos principales fueron I) la necesidad de que la inversión sea parte central de las estrategias de desarrollo sostenible, II) el deseo de conseguir el desarrollo sostenible a través de inversiones más responsables y III) la certeza de que los tratados de vieja generación no servían para lograr estos objetivos. La UNCTAD señaló que los acuerdos firmados principalmente en los años noventa constriñen de forma excesiva la capacidad nacional de legislar a favor del desarrollo sostenible y se enfocan de manera exclusiva en proteger a los inversores sin hacer lo suficiente para promover la inversión para el desarrollo $^{11}$. De esta forma, la UNCTAD define un dicotomía clara entre el antiguo modelo de TBI, cuyo único objetivo era proteger las inversiones, y el nuevo: proteger las inversiones pero de forma coherente con el resto de políticas públicas. En este sentido se entiende como nueva generación de TBI aquellos acuerdos que incorpo-

${ }^{9}$ Los TBI tienen plazos variables, que suelen oscilar entre 10 y 25 años. La página oficial de la UNCTAD cuenta con un buscador de todos los TBI firmados a lo largo de la historia. https:// investmentpolicy.unctad.org/international-investment-agreements.

${ }^{10}$ UNCTAD, Trade and Development Report 2010: Employment, globalization and development, United Nations Conference on Trade and Development, 2010. https://unctad.org/es/system/files/official-document/wir2010_en.pdf.

${ }^{11}$ UNCTAD, Investment Policy Framework for Sustainable Development, United Nations Conference on Trade and Development, p. 19, 2015. https://unctad.org/en/PublicationsLibrary/ diaepcb2015d5_en.pdf. 
ran algunas de las recomendaciones de la UNCTAD frente a la vieja generación de acuerdos, tanto concluidos como en vigor, que no las incorporan.

En este artículo pond remos especial atención en la vieja generación, ya que, aparte de ser la más numerosa ${ }^{12}$, es sin duda la que genera mayor conflictividad respecto al tema que nos ocupa. En palabras de la UNCTAD:

Los tratados de primera generación «muerden». Casi todos los casos actuales conocidos de solución de controversias entre inversores y Estados se basan en tratados celebrados antes de 2010, que en su mayor parte contienen formulaciones generales y vagas [...]. Los tratados de primera generación perpetúan incoherencias. El hecho de que sigan existiendo provoca superposiciones y fragmentación en las relaciones entre tratados, así como problemas de interacción ${ }^{13}$.

\section{TBI Y DERECHOS HUMANOS}

Podríamos definir tres conflictos principales entre los $\mathrm{TBI}^{14}$ y el DIDH: I) la vocación de estabilidad del primero frente al ímpetu transformador del segundo, II) la intersección entre intereses empresariales y derechos humanos y III) la forma en la que los TBI suponen una limitación a la capacidad legislativa de los Estados, en especial en materia de derechos humanos.

\subsection{TBI y DIDH: UN DEBATE CONCEPTUAL}

La colisión fundamental entre el RPI de vieja generación y el DIDH es conceptual, y existe desde la propia razón de ser de ambos sistemas. Los TBI buscan seguridad jurídica, que en el ámbito de las inversiones suele significar previsibilidad: tener información que permita saber qué va a suceder. Por ello, los TBI buscan mantener, dentro de lo posible, el statu quo existente en el momento en el que el inversor tomó la decisión de invertir. Para ello, las cláusulas de los acuerdos buscan restringir en la medida de lo posible la capacidad estatal de reforma legislativa en materias que puedan afectar a los inversores. Intereses que, como veremos más adelante, se relacionan de forma muy estrecha con los derechos humanos.

En cambio, el DIDH busca, por definición, cambiar el statu quo. Los derechos humanos se plantean como objetivos a lograr y no como metas ya alcanzadas y para ello es necesario fomentar cambios. Los Estados tienen la obligación inter-

${ }^{12}$ La UNCTAD calcula que tan sólo el 5\% de los TBI puede considerarse de nueva generación.

13 UNCTAD, Reforma del régimen de acuerdos internacionales de inversión: fase 2, United Nations Conference on Trade and Development, 2017, p. 3. Disponible en https://unctad.org/ system/files/official-document/ciimem4d14_es.pdf.

${ }^{14}$ A partir de este punto, a no ser que se especifique lo contrario, nos referimos a TBI de vieja generación. 
nacional, consagrada en numerosos documentos, de adoptar las medidas oportunas para dictar las disposiciones legislativas, ejecutivas y judiciales que fueran necesarias para hacer efectivos los derechos humanos ${ }^{15}$. En este sentido la Convención Americana sobre Derechos Humanos establece el deber de adoptar disposiciones de derecho interno:

Si en el ejercicio de los derechos y libertades mencionados en el artículo 1 no estuviere ya garantizado por disposiciones legislativas o de otro carácter, los Estados partes se comprometen a adoptar, con arreglo a sus procedimientos constitucionales y a las disposiciones de esta Convención, las medidas legislativas o de otro carácter que fueren necesarias para hacer efectivos tales derechos y libertades ${ }^{16}$.

De la misma forma, la Corte Interamericana de Derechos Humanos ha señalado que

la obligación estatal de adecuar la legislación interna a las disposiciones convencionales no se limita al texto constitucional o legislativo, sino que debe irradiar a todas las disposiciones jurídicas de carácter reglamentario y traducirse en la efectiva aplicación práctica de los estándares de protección de los derechos humanos ${ }^{17}$.

Las vocaciones contrapuestas de ambos sistemas, la disputa entre estabilidad y transformación, colocan al Estado, tal y como señalan Bohoslavsky y Justo ${ }^{18}$, en el dilema de incumplir sus responsabilidades internacionales en materia de derechos humanos, o cumplirlas corriendo el riesgo de infringir acuerdos de inversión.

\subsection{INTERESES DEL INVERSOR Y DERECHOS HUMANOS}

Como ya se ha expuesto, el Estado tiene una obligación internacional clara de tomar medidas en materia de derechos humanos y los TBI establecen una serie de disposiciones que tratan de limitar la capacidad del Estado de modificar las disposiciones legales que afecten a los intereses del inversor. Siguiendo este razonamiento, si los intereses del inversor están relacionados con los derechos humanos el Estado podrá estar en riesgo de incumplir sus obligaciones internacionales. La segunda gran tensión entre los dos sistemas aquí analizados surge porque no cabe duda de dicha relación: existe un riesgo claro de colisión entre los intereses empresariales y los derechos humanos.

${ }^{15}$ Artículo 2 del Pacto Internacional de Derechos Civiles y Políticos.

16 Artículo 2 de la Convención Americana

17 Corte IDH. Opinión Consultiva OC-21/14 de 19 de agosto de 2014. Serie A N. 21. párr. 65. Disponible en https://www.corteidh.or.cr/docs/opiniones/seriea_21_esp.pdf.

${ }_{18}$ Bohoslavsky, J.P. y Justo, J.B., «Inversiones Extranjeras y Derechos Humanos: entre la permanencia y el cambio», Revista de la Secretaría del Tribunal Permanente de Revisión, núm. 5 (3), 2015, pp. 65-94. Disponible en https://dialnet.unirioja.es/servlet/articulo?codigo=5830174. 
En este sentido cabe destacar el extenso trabajo llevado a cabo por la Comisión Interamericana de Derechos Humanos (CIDH), que ha destacado en varios documentos los principales puntos de fricción potenciales entre proyectos empresariales y derechos humanos. La CIDH ha señalado el claro riesgo existente en el caso de los actores empresariales que brindan servicios públicos esenciales para la garantía de los derechos humanos como la salud, la educación, agua potable, electricidad o seguridad social ${ }^{19}$. También ha destacado cómo puede afectar a los derechos humanos a través de la afectación del medio ambiente, la acción de empresas con proyectos de extracción o explotación de materias primas ${ }^{20}$. Así mismo, también ha hecho referencia a los derechos laborales ${ }^{21} \mathrm{o}$ a los posibles conflictos con los intereses de las empresas de seguridad privada ${ }^{22}$. En lo que respecta a la posible colisión entre proyectos extractivos y los derechos de los pueblos indígenas y las comunidades afrodescendiente, la CIDH ha afirmado que

los megaproyectos de infraestructura o desarrollo, tales como carreteras, canales, represas, puertos o afines, así como las concesiones para la exploración o explotación de recursos naturales en territorios ancestrales, pueden afectar a las poblaciones indígenas con consecuencias particularmente graves, ya que ponen en peligro sus territorios y los ecosistemas que allí se encuentran, por lo cual representan un peligro mortal para su supervivencia en tanto pueblos, especialmente en los casos en que la fragilidad ecológica de sus territorios coincide con su debilidad demográfica ${ }^{23}$.

Precisado lo anterior, podemos afirmar que los intereses de las ETN y los derechos humanos están estrechamente relacionados. Por ello, si el Estado, cumpliendo su ya argumentada obligación internacional, toma nuevas medidas en materia de derechos humanos, éstas pueden afectar negativamente a los intereses de los inversores. Siguiendo con dicho razonamiento, si los TBI limitan la capacidad regulatoria del Estado en materias relacionadas con los intereses de los inversores, directamente limitan la capacidad estatal de legislar en materia de derechos humanos.

${ }^{19}$ CIDH/REDESCA/INF.1/19. Comisión Interamericana de Derechos Humanos, Empresas y Derechos Humanos: Estándares Interamericanos, Organización de Estados Americanos, 2019, párrafo 115. Disponible en http://www.oas.org/es/cidh/informes/pdfs/EmpresasDDHH.pdf.

${ }^{20} \mathrm{CIDH}, 2019$, op. cit., párrafo 100.

${ }^{21}$ CIDH, 2019, op. cit., párrafo 99.

22 OEA/Ser.L/V/II, CIDH, Informe sobre Derechos Humanos y Seguridad Ciudadana, Organización de los Estados Americanos, párrafo 73, 2009. Disponible en https://www.cidh.oas. org/pdf\%20files/SEGURIDAD\%20CIUDADANA\%202009\%20ESP.pdf.

${ }^{23}$ OEA/Ser.L/V/II, CIDH, Pueblos indígenas, comunidades afrodescendientes y recursos naturales: protección de derechos humanos en el contexto de actividades de extracción, explotación y desarrollo, Organización de los Estados Americanos, párrafo 247, 2015. 


\subsection{TBI COMO LIMITACIÓN A LA CAPACIDAD REGULATORIA EN MATERIA DE DERE- CHOS HUMANOS}

La tensión entre TBI y capacidad regulatoria en materia de derechos humanos es ampliamente reconocida por Naciones Unidas. La UNCTAD ha señalado en diversas ocasiones la necesidad de salvaguardar el derecho de los Estados de tomar medidas legislativas a favor del interés público y de asegurar que los límites que imponen los TBI a la soberanía estatal no constrińan de forma excesiva su capacidad regulatoria ${ }^{24}$.

Los principios rectores sobre las empresas y los derechos humanos de Naciones Unidas también hacen referencia explícita a dicha tensión, señalando:

Los acuerdos económicos concluidos por los Estados, ya sea con otros Estados o con empresas -tales como tratados bilaterales de inversión, acuerdos de libre comercio o contratos de proyectos de inversión- les brindan oportunidades económicas. Pero también pueden afectar al marco normativo nacional de los gobiernos. Por ejemplo, los términos estipulados en acuerdos internacionales de inversión pueden restringir la capacidad de los Estados para aplicar plenamente nuevas leyes en materia de derechos humanos, o exponerlos, en caso contrario, al riesgo de arbitrajes internacionales vinculantes. Por lo tanto, los Estados deben asegurarse de que retienen las facultades normativas y regulatorias para proteger los derechos humanos en el marco de tales acuerdos, sin dejar de ofrecer la necesaria protección a los inversores ${ }^{25}$.

Del mismo modo, dicha fricción está siendo un aspecto a tener en cuenta en las negociaciones del proyecto de Tratado Vinculante sobre empresas y derechos humanos ${ }^{26}$. El segundo borrador revisado del texto ${ }^{27}$ alude a los TBI, declarando que los ya existentes deberán ser siempre interpretados e implementados de forma que no se vea socavada la capacidad estatal de cumplir con las obligaciones estipuladas en las convenciones e instrumentos de derechos humanos. También añade que

${ }^{24}$ UNCTAD, Trade and Development Report 2015: Reforming International Investment Governance, United Nations Conference on Trade and Development, p. XI, 2015. https:/unctad. org/system/files/official-document/wir2015_en.pdf.

${ }^{25}$ ONU, Principios Rectores sobre las empresas y los Derechos Humanos: Puesta en práctica del marco de las Naciones Unidas para «proteger, respetar y remediar», Organización de las Naciones Unidas, 2001, p. 13. Disponible en https://www.ohchr.org/documents/publications/guidingprinciplesbusinesshr_sp.pdf.

${ }^{26}$ El Consejo de Derechos Humanos de Naciones Unidas aprobó el 26 de junio de 2014 la Resolución 26/9, a través de la cual decide establecer un grupo de trabajo intergubernamental de composición abierta sobre las empresas transnacionales y otras empresas con respecto a los derechos humanos, cuyo mandato será elaborar un instrumento jurídicamente vinculante para regular las actividades de las empresas transnacionales y otras empresas en el derecho internacional de los derechos humanos. Resolución disponible en https://ap.ohchr.org/documents/dpage_e.aspx?si=A/HRC/RES/26/9.

${ }_{27}$ Con fecha de 6 de agosto de 2020. Disponible en https://www.ohchr.org/Documents/ HRBodies/HRCouncil/WGTransCorp/Session6/OEIGWG_Chair-Rapporteur_second_revised_ draft_LBI_on_TNCs_and_OBEs_with_respect_to_Human_Rights.pdf. 
todo nuevo tratado o acuerdo de inversión pactado por las partes debe ser compatible con dichas obligaciones ${ }^{28}$.

La preocupación de Naciones Unidas sobre el riesgo de que los TBI limiten la capacidad estatal de tomar medidas en materia de derechos humanos es clara. A continuación se analizan los aspectos de estos acuerdos que presentan un mayor riesgo.

\section{LOS TBI DE VIEJA GENERACIÓN: PUNTOS DE FRICCIÓN CON LA CAPACIDAD REGULATORIA DE LOS ESTADOS CON ESPECIAL REPERCUSIÓN EN MATERIA DE DERECHOS HUMANOS}

Estos acuerdos suelen incluir un apartado centrado en enumerar los derechos de los inversores y una parte más procedimental, en la que se estipulan los correspondientes mecanismos a utilizar, incluido el sistema de solución de controversias. Destacan por no incluir posibles obligaciones de los inversores respecto a los derechos humanos. Ningún TBI de vieja generación menciona a estos últimos, con la excepción del modelo noruego, que los incluye en su preámbulo ${ }^{29}$.

La mayoría de los tratados incluyen cláusulas similares o idénticas, ya que la mayoría de los Estados utilizan modelos o borradores de acuerdo que se modifican levemente según las negociaciones con cada contraparte. Las disposiciones destacan por ser vagas y poco concisas, circunstancia que, como veremos posteriormente, ha demostrado ser muy problemática, debido al amplio margen de interpretación que suscitan. En palabras de la UNCTAD:

Broad and vague formulations of IIA ${ }^{30}$ provisions have enabled investors to challenge core domestic policy decisions -for instance, in environmental, financial, energy and health policies. They have also generated unanticipated, and at times inconsistent, arbitral interpretations of core IIA obligations, resulting in a lack of predictability as to the kinds of State measures that might violate a specific IIA provision $^{31}$.

Son muchas las cláusulas propias de los TBI que podrían ser estudiadas, pero por motivos de espacio no centramos en tres: I) nación más favorecida, II) trato justo y equitativo y III) prohibición de la expropiación. Así mismo, se exponen las

${ }^{28}$ Artículo 14.5 del Segundo Borrador Revisado.

${ }^{29}$ JАСОВ, M., «International Investment Agreements and Human Rights», Institute for Development and Peace, Universität Duisburg Essen, 2010. Disponible en http://www.humanrights-business.org/international_investment_agreements_and_human_rights.pdf.

${ }^{30}$ International Investment Agreements.

31 UNCTAD, UNCTAD's Reform Package for the international Investment Regime, United Nations Conference on Trade and Development, 2018, p. 16. Disponible en https://investmentpolicy.unctad.org/publications/1190/unctad-s-reform-package-for-the-international-investment-regime-2018-edition-. 
características de los mecanismos encargados de interpretar dichas cláusulas: los tribunales internacionales de arbitraje.

\subsection{La Cláusula de Nación Más Favorecida (CNMF)}

La CNMF es uno de los elementos más cruciales del sistema de protección de inversiones. El DPI la ha utilizado tradicionalmente para definir la situación en la que el Estado concedente contrae la obligación, con respecto a otro Estado, de tratar a éste en condiciones que no sean peores al trato que ha estado otorgando u otorgará al tercer Estado más favorecido, en virtud de un tratado independiente o por alguna otra causa ${ }^{32}$. Pese a lo anterior, ante instancias arbitrales, los inversores extranjeros no suelen alegar discriminación argumentando que el Estado receptor haya aplicado medidas más favorables a inversores de terceros Estados. En cambio, suelen invocar la CNMF para tratar de acceder a condiciones de TBI entre el Estado receptor y terceros Estados que incluyan formulaciones más favorables que el acuerdo que regula su relación ${ }^{33}$. Está interpretación se dio en primer lugar en el caso Mafezzini vs. Espańa, en el que el tribunal aceptó la petición de un demandante argentino que, en base a la cláusula de CNMF del TBI Argentina-España, argumentaba que se le debía aplicar un arreglo más favorable contenido en el TBI Chile-España ${ }^{34}$. Al aceptar esta interpretación, los árbitros internacionales han desvirtuado los TBI originales, ya que han permitido a los inversores ir «eligiendo» las cláusulas que les favorezcan más de los diferentes tratados ratificados por el Estado receptor de la inversión ${ }^{35}$.

Esta cláusula no supone una limitación de la capacidad regulatoria por sí misma, pero eso no significa que no entrañe riesgos, ya que puede provocar que la aplicación de un TBI por parte de los tribunales de arbitraje diste mucho de lo buscado por los Estados parte. Esto puede suponer un problema especialmente delicado si tenemos en cuenta los actuales esfuerzos de muchos países por modificar su política de protección de las inversiones, ya que de incluir la disposición CNMF, los nuevos tratados podrían ser interpretados aludiendo a convenios de «vieja generación»"

32 Definición del Relator Especial Sr. Endre Ustor, en el Documento A/CN.4/L.127/ de la Comisión de Derecho Internacional de Naciones Unidas, 1968.

33 Bas Vilizzio, M. y Michelini, F., «Arbitraje de inversiones y derechos humanos: un análisis particular del caso Philip Morris contra Uruguay», Comisión Sectorial de Investigación Cientifica, Universidad de la República de Uruguay, 2019, p. 26. Disponible en https://www.csic.edu.uy/ sites/csic/files/Bas\%20Vilizzio_Arbitraje\%20de\%20inversiones\%20y\%20derecho\%20humanos $\% 20$ Un\%20an\%C3\%A1lisis\%20particular\%20del\%20caso\%20Philip\%20Morris\%20contra\%20Uruguay_FDER.pdf.

${ }^{34}$ Caso Ciadi N. ${ }^{\circ}$ ARB/97/7, p. 9.

35 UNCTAD, 2018, op. cit., p. 33.

36 UNCTAD, 2018, op. cit., p. 34. 


\subsection{Trato Justo y Equitativo (TJE)}

Otra cláusula con gran arraigo histórico en los tratados internacionales, el TJE fue originalmente concebido como una medida de garantizar un trato mínimo a los extranjeros ${ }^{37}$. Obliga a los Estados a ofrecer a los nacionales de otros países garantías mínimas contra la denegación de justicia, la arbitrariedad y la discriminación ${ }^{38}$. De nuevo desvirtuando en cierta medida el sentido original, se ha convertido en una disposición que los inversores utilizan para denunciar cualquier tipo de conducta estatal que consideren injusta respecto a sus intereses ${ }^{39}$. Así mismo, la vaguedad en la que normalmente se plantea ha dado mucho margen de interpretación a los tribunales de arbitraje ${ }^{40}$.

Uno de los principales retos que han surgido a partir de diversos laudos es la interpretación de que la cláusula TJE protege las «expectativas legítimas» del inversor. La amplitud de este concepto genera un riesgo para los Estados, ya que pueden ver constreñida su capacidad regulatoria y de generación de nuevas políticas en materias relacionadas con las inversiones. En referencia al TJE, el Tribunal de Arbitraje CIADI en el caso TECMED vs. México señaló:

El Tribunal Arbitral considera que esta disposición [...] exige de las Partes Contratantes del Acuerdo brindar un tratamiento a la inversión extranjera que no desvirtúe las expectativas básicas en razón de las cuales el inversor extranjero decidió realizar su inversión. Como parte de tales expectativas, aquél cuenta con que el Estado receptor de la inversión se conducirá de manera coherente, desprovista de ambigüedades y transparente en sus relaciones con el inversor extranjero, de manera que éste pueda conocer de manera anticipada, para planificar sus actividades y ajustar su conducta, no sólo las normas o reglamentaciones que regirán tales actividades, sino también las políticas perseguidas por tal normativa y las prácticas o directivas administrativas que les son relevantes ${ }^{41}$.

Siguiendo esta argumentación, el Estado puede llegar a ver reducida de forma muy amplia su capacidad de adoptar medidas legislativas en todo lo relevante a los intereses del inversor, que como ya se expuso se relacionan de forma directa con los derechos humanos. Los riesgos de este tipo de disposiciones son tales que la UNCTAD señala la necesidad de modificar los contenidos de las cláusulas TJE, asegu-

37 Dupuy, P.M. y Viñuales, J.E., «Human Rights and Investment Disciplines: Integration in Progress", International Investment Law, Baden Baden: Nomos, 2012, p. 8. Disponible en https://papers.ssrn.com/sol3/papers.cfm?abstract_id=2125205.

${ }^{38}$ Bohoslavsky, J.P. y Justo, J.B., op. cit., p. 77.

39 ЈАСОВ, M., op. cit., p. 44.

40 A modo de ejemplo, el modelo de TBI de España incluye la siguiente redacción: «Cada Parte Contratante otorgará a las inversiones de inversores de la otra Parte Contratante, trato acorde con el derecho internacional consuetudinario, incluido trato justo y equitativo, así como protección y seguridad plenas».

${ }^{41}$ Caso Ciadi N. ${ }^{\circ}$ ARB (AF)/00/2, párrafo 154. Disponible en http://icsidfiles.worldbank. org/icsid/ICSIDBLOBS/OnlineAwards/C3785/DC4872_Sp.pdf. 
rando que en todo caso se preserve la capacidad de los Estados de adaptar políticas según cambien sus objetivos ${ }^{42}$.

\subsection{Cláusula de expropiación}

Hablamos de expropiación directa cuando la inversión es nacionalizada o de otra forma hay una transferencia del título de propiedad o se incautan físicamente los activos. La indirecta, cuando sin alteración de la titularidad «se produce una interferencia estatal significativa en el uso de dicha propiedad o el disfrute de sus beneficios» ${ }^{43}$. Los TBI sólo permiten la expropiación realizada por causas de utilidad pública conforme a las disposiciones legales, en ningún caso de forma discriminatoria, y siempre debe existir una indemnización.

Los inversores han aprovechado la difusa definición de expropiación indirecta para desafiar medidas legislativas que han podido tener un efecto negativo en sus intereses ${ }^{44}$. El principal problema llega a la hora de definir la frontera entre políticas públicas legítimas (restricciones en materia de medioambiente, medidas de salud pública, etc.) y expropiaciones que deben ser compensadas económicamente. De no definirse de manera clara, pueden surgir situaciones en la que los Estados deban indemnizar a las ETN por tomar medidas legislativas legítimas.

En este sentido destaca el famoso caso del CIADI Piero Foresti, Laura de Carli y otros vs. Sudáfrica. En el año 2004, el Gobierno sudafricano llevó a cabo una serie de reformas legislativas con el objetivo principal de tomar medias para dejar atrás las políticas del apartheid. En dicho paquete de reformas incluyó la obligación de todas las empresas mineras de cumplir con dos requisitos: I) en una plazo de 10 años, el control del $26 \%$ de sus acciones deberían estar en manos de sudafricanos «históricamente en desventaja» y II) el deber de publicar planes de empleo equitativo dirigidos a la inclusión en las plantillas de un $40 \%$ de personas negras ${ }^{45}$. La respuesta de empresas italianas y luxemburguesas fue denunciar a Sudáfrica, aprovechando los TBI entre sus países de origen y este último, alegando que las medidas tomadas por el Gobierno sudafricano debían considerarse una expropiación indirecta, ya que modificaban ampliamente sus derechos, por lo que reclamaban una indemnización de 375 millones de dólares ${ }^{46}$. El Gobierno sudafricano argumentó que la supuesta expropiación estaría amparada en el Derecho Interno, ya que estaría justificada por diversos motivos, entre ellos la reparación de la privación de derechos provocada por el apartheid ${ }^{47}$. El proceso se resolvió mediante acuerdo de las

${ }^{42}$ UNCTAD, 2018, op. cit., p. 36.

43 Bohoslavsky, J.P. y Justo, J.B., op. cit., p. 73.

${ }^{44}$ UNCTAD, 2018, op. cit., p.37.

45 Caso Ciadi No ARB(AF)/07/1. Párrafo 56.

46 Según datos de la UNCTAD. Disponible en https://investmentpolicy.unctad.org/investment-dispute-settlement/cases/262/foresti-v-south-africa.

${ }^{47}$ Bas Vilizzio, M. y Michelini, F., 2019, op. cit., p. 28. 
partes, por lo que el laudo de 4 de agosto de 2010 no entró a analizar las cuestiones de fondo. Pese a ello la reacción de Sudáfrica fue inmediata, ya que el mismo año comenzó a tomar medidas para modificar su política respecto a los TBI. El Gobierno decidió no obligarse mediante nuevos acuerdos de inversión y revisó todos los TBI en vigor con vistas a su terminación ${ }^{48}$. En el año 2015 Sudáfrica dio por finalizados todos sus TBI con países europeos y desarrolló una nueva Ley de Protección de Inversiones, que presentó como principal novedad el abandono del sistema de solución de controversias del CIADI, sustituyéndose por una instancia doméstica ${ }^{49}$.

El caso expuesto sirve de ejemplo del riesgo que supone este tipo de cláusulas. En base a éstas, las empresas pueden estar legitimadas para denunciar medidas tomadas por el Estado en materia de derechos humanos, por «modificar ampliamente sus derechos» en contra de sus intereses.

\subsection{El SISTEMA DE SOlUCiÓN DE CONTROVERSIAS INVERSO-ESTADO (ISDS)}

La mayoría de TBI establece un sistema de solución de las controversias con un mecanismo inversor-Estado, mediante el cual las empresas nacionales de una de las dos partes que tengan inversión en el territorio de la otra parte podrán demandar directamente al Estado receptor de la inversión. Algunos tratados optan por resolver la disputa en los tribunales nacionales del Estado receptor, pero la mayoría alude a la fórmula del tribunal internacional de arbitraje. Existen varias instituciones a las que suelen acudir los Estados, entre las que destaca el Centro Internacional de Arreglo de Diferencias Relativas a Inversiones (CIADI), que forma parte del Grupo del Banco Mundial ${ }^{50}$. Otras instancias similares son la Corte Permanente de Arbitraje de La Haya, la Cámara de Comercio de Estocolmo o la Cámara Internacional de Comercio.

48 Carim, X., «International Investment Agreements and Africa's Structural Transformation: A Perspective from South Africa», Investment Policy Brief, núm. 4, South Centre, 2015 , p. 4. Disponible en https://www.southcentre.int/wp-content/uploads/2015/08/IPB4_IIAs-and-Africa\%E2\%80\%99s-Structural-Transformation-Perspective-from-South-Africa_EN.pdf.

49 Qumba, M.F., "South Africa's move away from international investor-state dispute: a breakthrough or bad omen for investment in the developing world?», De Jure Law Journal, 2019, p. 359. Disponible en https://www.researchgate.net/publication/337011094_South_Africa's_move_ away_from_international_Investor-State_arbitration.

50 Según su propia página web, «una de las fuentes más importantes de financiamiento y conocimiento para los países en desarrollo, está integrado por cinco instituciones que se han comprometido a reducir la pobreza, aumentar la prosperidad compartida y promover el desarrollo sostenible». Aparte del CIADI, está conformado por el Banco Internacional de Reconstrucción y Fomento, la Asociación Internacional de Fomento, la Corporación Financiera Internacional y el Organismo Multilateral de Garantía de Inversiones. Información disponible en https://www.bancomundial.org. 
La importancia de los tribunales de arbitraje es enorme y se han ocupado de un gran número de $\operatorname{casos}^{51}$. La primera demanda de un país latinoamericano tuvo como destinatario a Venezuela en el año 1996. Los países de América del Sur, América Central y el Caribe han sido demandados en 282 ocasiones, 206 de las cuales se reparten entre Argentina (62), Venezuela (52), México (33), Ecuador (25), Bolivia (17) y Perú $(17)^{52}$. De los 282 casos, en 179 hubo una resolución (por laudo de arbitraje o por acuerdo de las partes), resultando beneficiado el inversor en el 69\% de los casos. En cuanto a las consecuencias económicas, los tribunales de arbitraje han dictaminado el pago por parte de los Estados lationamericanos de un total de 31170 millones de dólares ${ }^{53}$.

La principal crítica que se le hace al sistema ISDS es la falta de transparencia de los tribunales, ya que normalmente los laudos sólo se hacen públicos si hay acuerdo entre las partes ${ }^{54}$. Otra de las principales críticas es la gran incertidumbre jurídica que provocan. Incluso los procedimientos con normas establecidas, como el CIADI, constituyen un tribunal ad hoc para cada caso que no tiene obligación de respetar los precedentes ${ }^{55}$. Así mismo, los sistemas de apelación son casi inexistentes. Ambas circunstancias provocan una gran inseguridad jurídica para todas las partes.

Los árbitros suelen ser elegidos entre un reducido número de profesionales de reconocido prestigio en el ámbito del derecho mercantil internacional, lo que suele dar lugar a que individuos compaginen sus laborales arbitrales en un caso con el asesoramiento a las partes en otros ${ }^{56}$. El gran conocimiento en derecho mercantil internacional es una ventaja para entrar a conocer el fondo de la disputa, pero puede ser un inconveniente a la hora de aplicar otras normas de derecho internacional, como las concernientes a los derechos humanos ${ }^{57}$. También destacan sus elevados honorarios, tres mil dólares por árbitro y día de sesión.

Como se ha expuesto, los tratados de vieja generación han supuesto y suponen una clara limitación a la capacidad regulatoria de los Estados en materia de derechos humanos. En el momento de negociar estos tratados los Estados desconocían en gran medida las consecuencias jurídicas y económicas que iban a tener dichos acuerdos, así como las conflictivas interpretaciones que iban a realizar los árbitros internacionales de muchas de las cláusulas ambiguas ${ }^{58}$. Pero en la actua-

51 Durante el año 2019 se alcanzó la simbólica cifra de 1000 disputas inversor-Estado. Datos disponibles en el buscador de disputas inversor-Estado de la UNCTAD https://investmentpolicy.unctad.org/investment-dispute-settlement.

52 Transnational Institute, ISDS en números: impactos de las demandas de arbitraje de inversores contra estados de América Latina y el Caribe, Transnational Institute Amsterdam, 2020. Disponible en https://www.tni.org/es/publicacion/isds-en-numeros.

${ }^{53}$ La cantidad total es mayor, pero hay muchos laudos que no se publican.

${ }^{54}$ UNCTAD, 2018, op. cit., p. 30.

55 JАСОВ, M., op. cit., p. 24.

56 ЈАСОВ, M., op. cit., p. 25.

57 JасОв, M., op. cit., p. 25.

58 En este sentido es muy clarificador el estudio realizado por Poulsen y Skovgard, en el que entrevistaron a treinta funcionarios que durante la década de los noventa fueron parte de nego- 
lidad ya no puede esgrimirse dicho argumento. Los Estados que negocian nuevos acuerdos de inversión son plenamente conscientes del potencial conflictivo de cada una de las disposiciones. A continuación se analizan tres ejemplos de posible acción estatal al respecto.

\section{TRES OPCIONES DE ACCIÓN ESTATAL ANTE LOS TBI DE VIEJA GENERACIÓN}

Una vez analizados los principales puntos de fricción entre TBI y obligaciones en materia de derechos humanos expondremos tres alternativas de acción estatal a través del ejemplo de tres países latinoamericanos que reflejan diferentes formas de afrontar el problema: mantenerse fiel al sistema tradicional de protección de las inversiones (México), impugnar el sistema y abandonarlo unilateralmente (Ecuador) y generar posibles alternativas más compatibles con los derechos humanos (Brasil).

\subsection{El CASO MEXICANO O QUE TODO SIGA IGUAL}

En la actualidad México forma parte de 29 TBI en vigor, así como de once tratados de libre comercio (TLC) que establecen un mecanismo de solución de controversias inversor-Estado. Las demandas resultantes de estos acuerdos lo convierten en el sexto país más demandado de América Latina ante tribunales de arbitraje, y ha sido condenado a pagar un total 254 millones de dólares a distintos inversores. A día de hoy tiene 13 casos pendientes en los que los inversores exigen un total de 8300 millones de dólares ${ }^{59}$.

México es el claro ejemplo de Estados que han decidido mantener una política de inversiones continuista y que no han abandonado la defectuosa «vieja generación» de TBI. En la actualidad, 19 de los 29 citados TBI ya han alcanzado la fase en la que el Gobierno mexicano podría optar unilateralmente por denunciarlos y comenzar así las negociaciones de nuevos acuerdos revisados en los que poder incluir nuevas disposiciones. Sin embargo, nada parece indicar que éste vaya a ser el camino a tomar. Más bien todo lo contrario, ya que en el año 2018 México entró a formar parte de la Convención del CIADI, convirtiéndose en el Estado parte 154.

ciaciones de TBI en representación de otros tantos países. En el mismo, afirman que ninguno de los funcionarios era consciente, en el momento de la negociación, de las importantísimas consecuencias que les esperaban a sus países y que hasta las primeras demandas recibidas y las primeras interpretaciones arbitrales no tenían una imagen real de los problemas jurídicos a los que estaban expuestos. Skovgaard Poulsen, L.N. y Aisbett, E., «When the claim hits: bilateral investment treaties and bounded rational learning», World Politics, vol. 65, núm. 2, 2013, pp. 273-313. Disponible en http:// eprints.lse.ac.uk/45035/1/When\%20the\%20Claim\%20Hits\%20(LSERO).pdf.

${ }^{59}$ Datos recopilados por el Transnational Institute, disponibles en https://isds-americalatina.org/mexico/. 
Este compromiso afianza los lazos del Estado mexicano con el régimen de protección de las inversiones y con los mecanismos de ISDS.

Así mismo, y pese a ser consciente, por haberlas sufrido de forma directa, de las posibles consecuencias de muchas disposiciones de los tratados de vieja generación, el Gobierno mexicano ha firmado recientemente varios acuerdos en los que mantiene exactamente las mismas cláusulas de los TBI de la década de los noventa: nación más favorecida, trato justo y equitativo, expropiación indirecta y resolución de controversias inversor-Estado ante un tribunal de arbitraje internacional, entre otras. Es el caso de los convenios firmados con Bahréin ${ }^{60}$ (con entrada en vigor en 2014), Kuwait ${ }^{61}$ (2016) o Emiratos Árabes Unidos ${ }^{62}$ (2018). En la misma línea cabe destacar que el 1 de julio de 2020 entró en vigor el Tratado de Libre Comercio entre México, Estados Unidos y Canadá (T-MEC ${ }^{63}$ ), que, pese a no ser un TBI, contiene un importante capítulo de inversiones ${ }^{64}$ que incluye todas las cláusulas cuyos riesgos han sido analizados en este trabajo, así como un sistema ISDS.

La postura mexicana continuista resalta aún más si se tiene en cuenta el acuerdo firmado con Brasil ${ }^{65}$ en el año 2015, que se adapta al modelo brasileño que analizaremos más adelante y cuyo contenido se distancia radicalmente de los «nuevos convenios de vieja generación» firmados por México en los últimos años. Es muy reseñable que pese a conocer los riesgos de los TBI más tradicionales y pese a firmar un acuerdo con Brasil con todas las características de la nueva generación, México se siga comprometiendo a nivel internacional mediante tratados que pueden significar una importante limitación para su capacidad de cumplir sus obligaciones en materia de derechos humanos.

\subsection{El CASO DE ECUAdOR: IRSE ¿PARA SIEMPRE?}

Ecuador representa una postura muy distante de la opción mexicana ya que, pese a mantener durante muchos años una relación de cordialidad con el sistema de ISDS, decidió dar un giro importante. En enero de 2008, menos de un año después de la llegada a la presidencia de Rafael Correa, Ecuador notificó la denuncia de nueve de los $26 \mathrm{TBI}$ en vigor de los que formaba parte ${ }^{66}$, los únicos que no habían gene-

${ }^{60}$ Disponible en https://investmentpolicy.unctad.org/international-investment-agreements/ treaties/bilateral-investment-treaties/3599/bahrain---mexico-bit-2012-.

${ }^{61}$ Disponible en https://investmentpolicy.unctad.org/international-investment-agreements/ treaties/bilateral-investment-treaties/3426/kuwait---mexico-bit-2013-.

${ }^{62}$ Disponible en https://investmentpolicy.unctad.org/international-investment-agreements/ treaties/bilateral-investment-treaties/3682/mexico---united-arab-emirates-bit-2016-.

${ }_{63}$ Texto completo disponible en https://www.gob.mx/t-mec.

${ }^{64}$ Capítulo 14 del T-MEC.

${ }_{65}$ Disponible en https://investmentpolicy.unctad.org/international-investment-agreements/ treaties/bilateral-investment-treaties/3665/brazil---mexico-bit-2015-.

${ }^{66}$ Cuba, El Salvador, Guatemala, Honduras, Nicaragua, Paraguay, República Dominicana, Rumanía y Uruguay. 
rado ninguna inversión ${ }^{67}$. En octubre del mismo año entró en vigor la nueva Constitución ecuatoriana, que en su artículo 422 hace referencia al arbitraje internacional:

«No se podrá celebrar tratados o instrumentos internacionales en los que el Estado ecuatoriano ceda jurisdicción soberana a instancias de arbitraje internacional, en controversias contractuales o de índole comercial, entre el Estado y personas naturales o jurídicas privadas ${ }^{68}$.

Utilizando dicho artículo como argumento, en julio de 2009, Ecuador denunció y dio por terminado el Convenio CIADI. Así mismo, el Gobierno solicitó una sentencia de la Corte Constitucional Transitoria en torno a la constitucionalidad de los 17 TBI restantes, que resolvió que dichos acuerdos contravenían la prohibición de ceder jurisdicción soberana del artículo $422^{69}$. En 2013, Correa impulsó la creación de la Comisión para la Auditoría Integral Ciudadana de los Tratados de Protección Recíproca de Inversiones y del Sistema de Arbitraje Internacional en Materia de Inversiones (CAITISA), la cual concluyó en su informe del 8 de mayo de 2017 que los TBI no contribuían a atraer inversión extranjera, recomendando su terminación ${ }^{70}$. Tan sólo unos días después, el 16 de mayo de $2017^{71}$, el Gobierno formalizó la salida de Ecuador de los 16 TBI restantes ${ }^{72}$.

Con la llegada de Lenin Moreno al poder, se percibe un posible cambio de rumbo, ya que el nuevo Gobierno anunció la intención de negociar nuevos tratados bilaterales de inversión ${ }^{73}$ y en 2019 celebró con Brasil un CFIA ${ }^{74}$, con un sistema de solución de controversias Estado-Estado, dejando de lado por primera vez el mecanismo inversor-Estado. Al ser consultada al respecto, la Corte Constitucional señaló que

${ }^{67}$ Bas Vilizzio, M., «Algunas reflexiones en torno al retiro de Bolivia, Ecuador y Venezuela del CIADI», Densidades, núm. 17, 2015, pp. 51-67. Disponible en https://www.researchgate. net/publication/285386774_Algunas_reflexiones_en_torno_al_retiro_de_Bolivia_Ecuador_y_ Venezuela_del_CIADI.

${ }^{68}$ Artículo 422 de la Constitución de la República del Ecuador del 20 de noviembre de 2008. Disponible en https://www.oas.org/juridico/pdfs/mesicic4_ecu_const.pdf.

${ }^{69}$ Véase como ejemplo la sentencia de la Corte Constitucional Transitoria N. ${ }^{\circ} 043-10-D T I-C C$, de 25 de noviembre de 2010, sobre la constitucionalidad del «Tratado entre la República del Ecuador y los Estados Unidos de América sobre promoción y protección recíproca de inversiones», de 1993. Disponible en http://portal.corteconstitucional.gob.ec:8494/FichaRelatoria.aspx?numdocumento $=043-10-$ DTI-CC.

${ }^{70}$ Herrera-Quenguan, J.C., «Explicando el Cambio de Postura de Ecuador sobre la IED, los Tratados y el Arbitraje de Inversión", Investment Treaty News, Instituto Internacional para el Desarrollo Sostenible, 2020. Disponible en https://cf.iisd.net/itn/es/2020/10/05/explaining-ecuadors-shifting-position-on-fdi-investment-treaties-and-arbitration-juan-carlos-herrera-quenguan/.

${ }^{71}$ Correa recibió numerosas críticas, ya que formalizó la salida de los TBI tan sólo ocho días de antes de abandonar la presidencia del Gobierno.

${ }^{72}$ Alemania, Argentina, Bolivia, Canadá, Chile, China, España, Estados Unidos, Francia, Italia, Países Bajos, Perú, Reino Unido, Suecia, Suiza y Venezuela. En el año 2010 se denunció el TBI con Finlandia.

${ }^{73}$ https://globalarbitrationreview.com/article/1159285/ecuador-begins-talks-over-new-bits.

${ }_{74} \overline{\text { Disponible en https://investmentpolicy.unctad.org/international-investment-agreements/ }}$ treaty-files/5887/download. 
los mecanismos de solución de disputas previstos en el Acuerdo, entre los cuales se encuentra el arbitraje, están exclusivamente destinados a solventar las disputas que puedan surgir entre las Partes, esto es, entre Estados. Esta resolución de disputas no es una competencia propia del orden jurídico interno de un Estado, por lo que al pactar arbitraje en el presente Acuerdo, no se está atribuyendo una competencia de esta naturaleza a un organismo internacional o supranacional ${ }^{75}$.

A la espera de los resultados de las negociaciones de los nuevos tratados, Ecuador sigue siendo uno de los mejores ejemplos de ruptura con el sistema de protección de inversiones. Esta impugnación del sistema tuvo un marcado carácter ideológico e importantes motivaciones partidistas, por lo que existen serias dudas sobre si dicha postura se mantendrá en el tiempo.

\subsection{Brasil: los CFIA como alternativa a los TBI de Vieja Generación}

Brasil es uno de los casos más interesantes en relación con el sistema de protección de inversiones, ya que puede considerarse el único país del mundo con un peso económico relevante que nunca ha firmado un TBI y que se ha mantenido ajeno al sistema ISDS $^{76}$. Pese a ello, Brasil ha sido tradicionalmente uno de los Estados con mayor captación de IED, situándose en la quinta posición mundial durante el año $2019^{77}$.

Entre 1994 y 1999 Brasil firmó catorce acuerdos, pero ninguno de ellos fue aprobado por el Congreso brasileño. Los argumentos utilizados fueron los períodos de tiempo demasiado extensos por los que se comprometía al Estado, la discriminación que significaría privilegiar a los inversores extranjeros frente a los nacionales y los posibles problemas de constitucionalidad en relación con la solución de controversias mediante el arbitraje inversor-Estado ${ }^{78}$. En el año 2002 se creó un Grupo de Trabajo Interministerial que decidió retirar dichos acuerdos del Congreso ${ }^{79}$.

Pese a no haber ratificado ningún TBI, Brasil no ha dejado de lado la regulación de la IED, pero ha buscado una alternativa que subsane los defectos del sistema de protección tradicional. A partir de 2015, Brasil comenzó a firmar un nuevo

75 Sentencia N. ${ }^{\circ}$ 34-19-TI/19, de 27 de junio de 2020, de la Corte Constitucional de Ecuador. Disponible en http://portal.corteconstitucional.gob.ec:8494/BuscadorRelatoria.aspx.

76 Aстіs, E., «Brasil y la promoción de Tratados Bilaterales de Inversión: El fin de la disyuntiva», Latin American Journal of International Affairs, vol. 6, núm. 1, 2014, pp. 18-33.

77 Datos de la Comisión Económica para América Latina y el Caribe de Naciones Unidas (CEPAL). Disponible en https://www.cepal.org/es/publicaciones/ie.

${ }^{78}$ Bas Vilizio, M., «Solución de controversias en los tratados bilaterales de inversión: mapa de situación en América del sur", Revista de la Secretaría del Tribunal Permanente de Revisión, núm. 5 (3), 2015, pp. 233-253. Disponible en https://redib.org/Record/oai_articulo935776-soluci $\% \mathrm{C} 3 \% \mathrm{~B} 3 n$-de-controversias-en-los-tratados-bilaterales-de-inversi $\% \mathrm{C} 3 \% \mathrm{~B} 3 \mathrm{n}$-mapa-de-situaci\%C3\%B3n-en-am\%C3\%A9rica-del-sur.

${ }^{79}$ ACTIS, E., op. cit., p. 23. 
tipo de tratado a los que denomina Acuerdos de Cooperación y Facilitación de Inversiones (CFIA por sus siglas en inglés). Estos documentos rompen de manera clara con el modelo tradicional de los TBI. El CFIA entre Brasil y la India ${ }^{80}$, firmado el 25 de enero de $2020^{81}$, es un claro ejemplo del nuevo rumbo que pueden tomar los TBI para enmendar las deficiencias de la vieja generación y generar un sistema de protección de inversiones que no colisione con las obligaciones en materia de derechos humanos.

Dicho acuerdo destaca, en primer lugar, por renunciar a la inclusión de las cláusulas más conflictivas de los TBI tradicionales y por aumentar la concreción de las disposiciones que sí se mantienen. Por ejemplo, el texto no hace ninguna referencia al estándar de trato justo y equitativo ${ }^{82}$, ni a la cláusula de nación más favorecida, y de forma expresa sólo incluye la expropiación directa, que sólo ocurre cuando «an investment is nationalised or otherwise directly expropiated through formal transfer tittle or outright seizure ${ }^{83}{ }_{\text {». }}$. Respecto a la cláusula de trato nacional, especifica que será otorgado en "circunstancias similares» ${ }^{84}$ y ańade, para mayor certeza, que las circunstancias similares dependen de la totalidad de las mismas y en ningún caso se podrá interpretar obligando a las partes a compensar desventajas intrínsecas que resulten del carácter extranjero del inversor ${ }^{85}$. De esta forma, el convenio se deshace de toda posible disposición que pueda significar un perjuicio importante para la capacidad regulatoria de ambas partes. En este sentido, el artículo 4.2 añade que ningún elemento del tratado podrá ser interpretado en un sentido que impida a una parte la adopción o mantenimiento de medidas de acción afirmativas a favor de grupos vulnerables.

En lo que respecta a los mecanismos de solución de controversias, en línea con la posición tradicional de Brasil al respecto, el acuerdo renuncia a la posibilidad de un arbitraje inversor-Estado. En cambio, opta por incluir un procedimiento de prevención de las disputas ${ }^{86}$, al que los Estados parte podrán acudir si consideran que la otra parte ha llevado a cabo una conducta que pueda ir en contra de lo estipulado en el tratado. La parte interesada deberá presentar un informe con sus alegaciones al Joint Comittee, órgano encargado de la administración del tratado formado por representantes gubernamentales de ambas partes ${ }^{87}$, que tomará una decisión al respecto. En el caso en el que la disputa esté relacionada con un único inversor, los

${ }^{80}$ Disponible en https://investmentpolicy.unctad.org/international-investment-agreements/ treaties/bilateral-investment-treaties/4910/brazil---india-bit-2020-.

${ }^{81}$ Aún no ha entrado en vigor.

${ }^{82}$ Dietrich Brauch, M., «¿Lo Mejor de Dos Mundos? El Tratado de Cooperación y Facilitación de Inversiones entre Brasil e India», Investment Treaty News. 2020. Disponible en https:// www.iisd.org/itn/es/2020/03/10/the-best-of-two-worlds-the-brazil-india-investment-cooperationand-facilitation-treaty-martin-dietrich-brauch/.

${ }^{83}$ Artículo 6.3.

${ }_{84}$ Artículo 5.1.

${ }^{85}$ Artículo 5.3.

${ }^{86}$ Artículo 18.

${ }^{87}$ Regulado en el artículo 13. 
representantes de éste serán escuchados durante el proceso, pero en ningún caso tendrán la opción de iniciar el mismo. Si se da la circunstancia de que las partes no quedan satisfechas con el procedimiento de prevención de disputas, existe la opción de establecer un tribunal arbitral $a d$ hoc entre las propias partes, o, siempre mediante acuerdo mutuo, acudir a una institución permanente de arbitraje. En ningún caso el tribunal de arbitraje podrá estipular una compensación económica ${ }^{88}$ y el procedimiento sólo podrá ser iniciado por uno de los dos Estados, nunca por un inversor.

Otro de los aspectos más destacables del acuerdo es que, al igual que todos los CFIA participados por Brasil, incluye un apartado de obligaciones y responsabilidades de los inversores, e incluso establece disposiciones respecto a la Responsabilidad Social Corporativa (RSC) de éstos. El tratado establece que tanto los inversores como las inversiones deben desarrollar sus mejores esfuerzos para conseguir «the highest possible level of contribution to the sustainable development of the Host State and the local community ${ }^{89}{ }$. A sí mismo, determina que los inversores deberán esforzarse en acatar una serie de principios voluntarios y estándares de RSC, entre los que destacan los derechos humanos reconocidos internacionalmente de aquéllos involucrados en las actividades de las compañías.

Pese a lo innovador y alejado de las prácticas de la vieja generación de esta última medida, defendemos que estos acuerdos aún podrían ser más ambiciosos y sustituir los términos como "deberán esforzarse» o "deberán poner todo su empeño» por un lenguaje que establezca de forma más clara la obligación de cumplir, como sí hace en los artículos relacionados con las obligaciones en materia de impuestos o adquisiciones ${ }^{90}$. Así mismo, consideramos que la exclusión del capítulo de obligaciones y responsabilidades de los inversores de las materias susceptibles de ser sometidas a arbitraje entre las partes es una oportunidad perdida. La hipotética situación en la que un Estado pueda llegar a iniciar un procedimiento de arbitraje contra la otra parte sobre la base de que una empresa de esta nacionalidad no está esforzándose lo suficiente por respetar los derechos humanos en su territorio abre todo un panorama de interesantes posibilidades.

Pese a estos últimos aspectos, el camino tomado por Brasil dibuja de forma clara un posible escenario en el que el fomento de la inversión extranjera no colisione con las obligaciones internacionales de los Estados en materia de derechos humanos.

\section{CONCLUSIONES}

Los TBI de «vieja generación» contienen cláusulas y mecanismos de resolución que pueden llegar a limitar de forma sustancial la capacidad regulatoria de los Estados receptores en materias relacionadas con las inversiones extranjeras. Los

\footnotetext{
${ }^{88}$ Artículo 19.2

${ }^{89}$ Artículo 12.1.

90 Artículo 11.
} 
intereses de los inversores son tan amplios y tan interrelacionados con los derechos humanos que la limitación de la posibilidad de los Estados de llevar a cabo medidas legislativas que los puedan afectar de forma negativa supone un claro riesgo de entorpecer la capacidad de los países de cumplir sus obligaciones en materia de derechos humanos.

Ante tal escenario, resulta necesaria una revisión profunda de los acuerdos que fomentan la inversión que permita hacerlos compatibles con la protección de los derechos humanos. Por ello, los Estados deben aprovechar el momento actual y, siguiendo el modelo brasileńo, negociar nuevos convenios que establezcan cláusulas menos conflictivas y mejor definidas, que incorporen obligaciones para los inversores y que abandonen el modelo de solución de controversias inversor-Estado que tantos quebraderos de cabeza ha generado. De lo contrario, los Estados que sigan comprometiéndose ante nuevos TBI que incluyan las antiguas cláusulas, cuyas consecuencias negativas son ya conocidas, estarán tomando la decisión, voluntaria y consciente, de limitar en gran medida su capacidad de cumplir sus obligaciones internacionales en materia de derechos humanos.

ReCibido: septiembre de 2020; ACEPTADo: diciembre de 2020 



\section{REVISORES}

María Dolores Adam Muñoz (Universidad de Córdoba)

Yésica Álvarez (Universidad de La Laguna)

Miguel Ángel Boldova Pasamar (Universidad de Zaragoza)

Antonio Cayón Galiardo (Universidad Complutense de Madrid)

María del Pilar Diago Diago (Universidad de Zaragoza)

Lucas Sebastián de Erice Aranda (Universidad de La Laguna)

María José Fernández Pavés (Universidad de Granada)

Gabriel García Cantero (Universidad de Zaragoza)

Pedro González de la Fe (Universidad de Las Palmas de Gran Canaria)

Andrés González Sanfiel (Universidad de La Laguna)

Ulises Hernández Plasencia (Universidad de La Laguna)

Mar Jimeno Bulnes (Universidad de Burgos)

Arantza Libano Beristain (Universidad Autónoma de Barcelona)

José Luis Linares Pineda (Universidad de Girona)

Ángel Lobo Rodrigo (Universidad de La Laguna)

Cesare Maioli (Universitá di Bologna)

Ruth Martinón Quintero (Universidad de La Laguna)

José María Miquel González (Universidad Autónoma de Madrid)

Cristóbal Molina Navarrete (Universidad de Jaén)

María del Carmen NúñEz Lozano (Universidad de Huelva)

Lucas Pérez Martín (Universidad de Las Palmas de Gran Canaria)

Javier Plaza Penadés (Universidad de Valencia)

Encarnación Ricart Martí (Universidad Rovira y Virgili de Tarragona)

Gloria Pilar Rojas Rivero (Universidad de La Laguna)

Eloy Ruiloba García (Universidad de Málaga)

Gumersindo Ruiz Bravo de Mansilla (Universidad de Málaga)

Ambrosio Sampere Flores (Universidad de Murcia)

María Elena SÁnchez JordÁn (Universidad de La Laguna)

José Luis Sánchez-Parodi Pascua (Universidad de La Laguna)

Dulce María Santana Vega (Universidad de Las Palmas de Gran Canaria)

José María Souvirón Morenilla (Universidad de Málaga)

José Suay Rincón (Universidad de Las Palmas de Gran Canaria)

José Manuel Ventura Ventura (Universidad de La Rioja)

Francisco Villar Rojas (Universidad de La Laguna)

María Zambonino Pulito (Universidad de Cádiz) 

INFORME DEL PROCESO EDITORIAL DE ANALES DE LA FACULTAD DE DERECHO DE LA UNIVERSIDAD DE LA LAGUNA 37, 2020

El equipo de dirección se reunió a finales del mes de enero de 2021 para tomar decisiones sobre el proceso editorial del número 37 de AFDULL. El tiempo medio transcurrido entre recepción, evaluación, aceptación, edición y publicación final de los trabajos fue de cuatro meses.

Estadística:

Núm. de trabajos recibidos: 4 .

Núm. de trabajos aceptados para publicación: 4 (100\%).

Media de revisores por trabajo: 2 .

Media de tiempo entre envío y aceptación: 4 meses.

Media de tiempo entre aceptación y publicación: 2 meses.

Los revisores varían en cada número, en atención al tema de los trabajos presentados. 

(Adoptadas por el Consejo de Redacción en su sesión de 9 de abril de 2018; pendientes de ratificación por la Junta de la Facultad de Derecho)

Primera. La revista se publica en formato digital, en un número anual, con dos fascículos semestrales a través de la plataforma de gestión de revistas on line de la Universidad de La Laguna: http://revistas.webs.ull.es/index.php/derecho. Los trabajos que se presenten al proceso de selección para su publicación deberán cumplir las siguientes normas:

a) Plazo y forma de presentación. La revista tiene permanentemente abierta su convocatoria de propuestas de publicación. Las propuestas podrán ser sometidas a consideración por sus autores a través de la plataforma de gestión de revistas on line de la Universidad de La Laguna: http://revistas.webs.ull.es/index.php/derecho.

b) Autores. Solo podrán presentar trabajos en la revista aquellas personas que reúnan la cualidad de tituladas en alguna de las enseñanzas universitarias oficiales de grado, máster y doctorado, o categorías equivalentes. Los autores deberán identificar su categoría académica y/o profesional, así como cuál es la institución a la que pertenecen.

c) Temática. Los trabajos deben ser investigaciones de contenido jurídico.

Excepcionalmente y de manera subsidiaria podrán incluirse trabajos de materias afines si los miembros del Consejo de Redacción asistentes unánimemente así lo consideran.

d) Estructura y formato de los trabajos.

I. Para la sección Artículos: los trabajos no deben exceder de los 60000 caracteres con espacios (unas 20 páginas) y tendrán un título (en español e inglés), como mínimo tres palabras clave (en español e inglés) y un resumen (en español e inglés). No deberá incluirse ni sumario ni bibliografía final. Las propuestas de publicación se presentarán en archivo en formato editable: Word o rtf.

II. Para la sección Comentarios, de legislación y jurisprudencia: los trabajos no deben exceder de los 30000 caracteres con espacios (unas 10 páginas) y tendrán un título (en español e inglés), como mínimo tres palabras clave (en español e inglés) y un resumen (en español e inglés). No deberá incluirse ni sumario ni bibliografía final. Las propuestas de publicación se presentarán en archivo en formato editable: Word o rtf.

III. El formato del texto principal será Times New Roman, a espacio y medio, tamańo de letra 12; y para las notas a pie de página es Times New Roman, a un espacio y con tamaño de letra 10. Las normas para las citas son las siguientes: A) artículos de revistas. Ejemplo: SAavedra Ruiz, J., «La iniciativa del tribunal en el acto del juicio oral», Cuadernos de Derecho Judicial, n. ${ }^{\circ} 10,1994$, p. 13 y ss. B) libros/monografías. Ejemplo: Ortells Ramos, M., El proceso penal abreviado, Comares, Granada, 1997.

e) Idioma. Los trabajos deberán estar escritos en lengua espańola, o en alguna lengua extranjera de relevancia en el ámbito jurídico siempre que la revista cuente con revisores que conozcan la lengua extranjera y sean expertos en el área de conocimiento de la propuesta presentada. En todo caso, el título, las palabras clave y el abstract deberán presentarse en español e inglés. 
f) Originalidad de los trabajos. Todos deben ser inéditos y no deben estar pendientes de publicación en otra revista o libro.

Segunda. La presentación de un trabajo en la revista Anales de la Facultad de Derecho de la Universidad de La Laguna conlleva el conocimiento y la aceptación de las siguientes normas por parte de los autores:

1. Es condición para la publicación que el autor o autores ceda(n) a la revista, en exclusiva, los derechos de reproducción, así como que consientan su inclusión en bases de datos, catálogos, bibliotecas, índices o servidores que permitan la mayor difusión de las investigaciones. Si se producen peticiones de terceros para reproducir o traducir artículos o partes de los mismos, la decisión corresponderá al Consejo de Redacción.

2. De las opiniones sustentadas en los trabajos firmados responden exclusivamente sus autores. La publicación de los diferentes artículos no implica adhesión ni conformidad de la revista con las opiniones mantenidas por los autores.

Tercera. Se asignará uno o dos evaluadores, preferiblemente externos, por cada uno de los originales presentados, según la materia sobre la que versen los mismos, para que informen en el plazo que se establezca sobre la conveniencia de su publicación. La evaluación será anónima en todo momento, de manera que los autores no conocerán quién evaluó su trabajo ni el evaluador conocerá quién es el autor.

Cunta. Pese a ser la evaluación anónima, en el caso de concurrir causa de abstención en alguno de los miembros propuestos o cuando este lo proponga de manera motivada, se podrá designar a otro/s evaluador/es experto/s en la materia que se evalúa.

Quinta. Cada evaluador rendirá su informe teniendo en cuenta los siguientes criterios: la calidad y rigor de los argumentos presentados; la oportunidad y relevancia del artículo; la creatividad, metodología, propuestas y aportaciones; así como la adecuación a las normas de publicación. Los informes tendrán carácter confidencial y reservado.

Sexta. Una vez transcurrido el plazo para presentar los informes de evaluación, se reunirá el Consejo de Redacción, al que se dará cuenta del punto en el que se encuentra el proceso, llevándose a cabo la valoración del resultado de las evaluaciones. Cuando exista contradicción entre los informes emitidos, el Consejo de Redacción designará a un tercer experto en la materia, para que proceda a una nueva evaluación.

SÉptima. Se trasladará al autor el resultado de la evaluación y, en su caso, las modificaciones sugeridas por los expertos, con la advertencia de que el Consejo de Redacción se reserva el derecho a no publicar el original presentado cuando no se observaren las modificaciones propuestas por los expertos.

Octava. Cuando algún miembro del Consejo de Redacción fuere autor del original presentado deberá ausentarse de las votaciones. 


\section{Servicio de Publicaciones \\ Universidad de La Laguna}

